NBER WORKING PAPER SERIES

\title{
THE DYNAMICS AND SPILLOVERS OF MANAGEMENT INTERVENTIONS: EVIDENCE FROM THE TRAINING WITHIN INDUSTRY PROGRAM
}

\author{
Nicola Bianchi \\ Michela Giorcelli \\ Working Paper 28833 \\ http://www.nber.org/papers/w28833 \\ NATIONAL BUREAU OF ECONOMIC RESEARCH \\ 1050 Massachusetts Avenue \\ Cambridge, MA 02138 \\ May 2021
}

\begin{abstract}
We thank Philipp Ager, John Asker, Andy Atkenson, Simon Board, Ryan Boone, Bruno Caprettini, Dora Costa, Alessandra Fenizia, Mitch Hoffman, Taylor Jaworski, Giampaolo Lecce, Adriana Lleras-Muney, Claudia Martinez, Niko Matouschek, Joel Mokyr, Giuseppe Nicoletti, Jagadeesh Sivadasan, Nico Voigtlaender, Melanie Wasserman, as well as seminar and conference participants at U. Bocconi, U. of Bologna, Chicago Booth, Columbia GSB, Empirical Management Conference, Erasmus University Rotterdam, HBS, KU Leuven, MIT, Monash U., Mountain West Economic History Conference, NBER Summer Institute, NYU Stern, OECD Productivity Forum, PUC-Rio de Janeiro, PUC-Santiago, Queen's Smith School of Business, UBC, UCLA, UCSD, U. Torcuato Di Tella, U. of New South Wales, U. of Queensland, U. of Sydney, and Yale U. We are grateful to Dmitri Koustas and James Lee for kindly sharing with us the war contracts data and the 1939 census data, respectively. Juan Rojas and Zhihao Xu provided outstanding research assistance. The views expressed herein are those of the authors and do not necessarily reflect the views of the National Bureau of Economic Research.
\end{abstract}

NBER working papers are circulated for discussion and comment purposes. They have not been peer-reviewed or been subject to the review by the NBER Board of Directors that accompanies official NBER publications.

(C) 2021 by Nicola Bianchi and Michela Giorcelli. All rights reserved. Short sections of text, not to exceed two paragraphs, may be quoted without explicit permission provided that full credit, including $(\odot)$ notice, is given to the source. 
The Dynamics and Spillovers of Management Interventions: Evidence from the Training Within Industry Program

Nicola Bianchi and Michela Giorcelli

NBER Working Paper No. 28833

May 2021

JEL No. J24,L2,M2,M5,N34,N64,O15,O32,O33

\begin{abstract}
This paper examines the long-term and spillover effects of management interventions on firm performance. Under the Training Within Industry (TWI) program, the U.S. government provided management training to firms involved in war production between 1940 and 1945. Using a newly collected panel dataset on all 11,575 U.S. firms that applied to the program, we find that the TWI training had positive and long-lasting effects on firm performance and the adoption of beneficial managerial practices. Moreover, it generated complementarities among different types of training and had positive spillover effects on the supply chain of trained firms.
\end{abstract}

\author{
Nicola Bianchi \\ Kellogg School of Management \\ Northwestern University \\ 2211 Campus Drive \\ Evanston, IL 60208 \\ and NBER \\ nicola.bianchi@kellogg.northwestern.edu \\ Michela Giorcelli \\ Department of Economics \\ University of California at Los Angeles \\ Bunche Hall 9262 \\ 315 Portola Plaza \\ Los Angeles, CA 90095 \\ and NBER \\ mgiorcelli@econ.ucla.edu
}




\section{Introduction}

Economists have documented large and persistent variations in productivity across establishments in both developed and developing countries (Syverson, 2004; Foster, Haltiwanger, and Syverson, 2008; Hsieh and Klenow, 2009), which are strongly correlated with the adoption of different managerial practices (Ichniowski, Shaw, and Prennushi, 1997; Bloom and Van Reenen, 2007). Moreover, more recent papers have shown that management has causal effects on firm performance, confirming its role in driving differences in productivity (Bloom et al., 2013a; Giorcelli, 2019).

However, much less is known about the long-term dynamic impact of management on firm outcomes and its spillover effects on other companies. On the one hand, the so-called "Toyotaway" hypothesis states that a single management intervention can put firms on a virtuous cycle of continuous improvements (Liker, 2004). For example, after an initial positive shock to management, complementarities among managerial areas or positive spillovers along the supply chain could make it easier for firms to get better over time (Womack, Jones, and Roos, 1990). On the other hand, the beneficial effects of management interventions may be not sustainable over time if turnover of good managers and changes in market conditions lead firms to abandon good practices (Bloom et al., 2020).

This paper studies the long-term dynamic and spillover effects of management interventions on firm performance, using evidence from a unique historical episode, the Training Within Industry (hereafter, TWI) program. The TWI program was a voluntary U.S.-governmentsponsored program that offered free in-plant management training to U.S. firms involved in war production between 1940 and 1945. It encompassed interventions in three main areas, called J-modules. The Job-Instructions (J-I) module taught supervisors and managers how to establish standard procedures for operations, the Job-Relations (J-R) module taught how to manage and motivate workers, and the Job-Methods (J-M) module taught how to introduce improvements to current production processes. While the initial plan of the U.S. government was to train all the 11,575 U.S. applicant firms in all the three J-modules, limited funding and personnel constraints made this goal unreachable. As a result, only 7 percent of applicants received training in all three J-modules, 48 percent received no training at all, and the others received training in either one or two J-modules.

We use a new panel dataset with information on the population of 11,575 U.S. firms that applied to the TWI program. For each applicant, we digitized detailed information on its participation in the program, the J-module training received (if any), and its upstream and downstream companies. We then matched this information to their balance sheets and income statements from 1935 to 1955. Overall, applicant firms were large companies operating 
in different economic sectors and geographical areas. In 1939, they employed 40 percent of the U.S. manufacturing workforce. In spite of their prominence in the U.S. economy, the data indicate that they were not well managed, which confirms the need of management training.

Our empirical strategy measures the effects of the TWI program by comparing applicant firms that received the training to applicant firms that did not receive it, over a period of time from five years before to ten years after the training period. We show that trained and nontrained firms had statistically similar characteristics at baseline and were located in statistically similar counties. Moreover, the probability of being trained in a given location was not autocorrelated over time, indicating that the TWI administration did not favor firms located in certain regions during the implementation of the program. Finally, and more importantly for our difference-in-differences specification, trained and nontrained firms were following statistically indistinguishable trends in performance before the start of the TWI program.

The historical records revealed that the fact that only some firms were eventually trained depended on idiosyncrasies in the implementation of the TWI program. For organizational purposes, applicant firms were divided into smaller geographical groups, called subdistricts. The in-plant training was then carried out by TWI instructors, whom the TWI administration trained to teach one J-module before assigning them to a given subdistrict. The lack of sufficient manpower and the inability of TWI instructors to teach in multiple subdistricts or to teach more than one module created imbalances in the composition of instructors across subdistricts and over time. As a result, some applicants received training only in some J-modules, while others did not receive any training at all.

We find four key results. First, the effects of the TWI training on firm performance were positive and lasted for at least ten years after the program implementation. For example, sales of trained firms increased by 5.3 percent within one year of the TWI training, compared with nontrained applicants. This effect peaked at 21.7 percent in period eight and then decreased to 16 percent in period ten. The effects on productivity were large and persistent, spanning from a 6-percent increase within one year of the training to a 27 -percent increase after ten years. These results were large and significant in all economic sectors, but manufacturing and service firms enjoyed the largest benefits.

Second, after assessing the overall effect of the TWI program, we start opening the black box of training by establishing a link between the content of the J-modules and the adoption of different managerial practices. The data indicate that trained firms achieved higher productivity by improving only the managerial practices related to the specific J-module received. For example, firms trained in J-R learned how to motivate workers and resolve internal disputes. Consistent with their training, they increased spending for performance-based bonuses, became 
more likely to report spending for on-the-job training, and experienced fewer strikes. We find this result analyzing both plant-level survey data and firm-level financial statements. Overall, our initial findings support the "Toyota-way" hypothesis. Trained firms were able to improve their performance for many years after training. Moreover, they experienced long-lasting changes in managerial practices.

Third, we document the existence of complementarities among managerial practices by exploiting the fact that some applicant firms received training in multiple J-modules. For example, firms that received the J-R training with another module experienced fewer strikes and were more likely to report spending for on-the-job training than firms that received the $\mathrm{J}-\mathrm{R}$ module by itself. This finding is one of the first empirical tests of a core component of the "Toyota-way" hypothesis. Due to complementarities, receiving one type of training can decrease the cost of further improvements in other managerial areas, making it easier for trained firms to keep getting better over time.

Fourth, the TWI program generated positive spillover effects on the supply chain of trained firms. Specifically, after applicants received the training, their upstream and downstream firms started becoming more productive. Remarkably, both the trained applicants and the firms in their supply chain improved their management practices in similar ways, which suggests that there was a transfer of managerial knowledge from the trained firms. For example, firms in the supply chain of applicants that received the J-R training also became less likely to experience worker strikes and more likely to report spending for on-the-job training, mimicking the same changes implemented by the trained firm. In addition to sharing their newly acquired knowledge, trained applicants became more likely to select better upstream and downstream firms after receiving the training. These findings suggest another channel through which the program might have allowed trained firms to achieve long-lasting improvements.

Conversely, we do not find evidence of spillovers on other U.S. war contractors that had been eligible to participate in the TWI program but did not apply. The fact that these firms were not damaged by the presence of trained firms nearby does not necessarily mean they were immune to losing customers to the trained firms. While it is true that the trained firms may have gained higher market shares at the expense of nonapplicant companies, in fact they could have done this without poaching the latter's current customers - because of the strong economic growth experienced in the U.S. during the post-WWII era.

Notably, trained firms were able to sustain their increased productivity in the long run even in the face of high turnover of top managers after WWII. This result indicates that the TWI program had a strong firm-specific component that stayed within the firm even after many trained managers left. Finally, we find that other war-related factors, such as war 
contracts awarded by the government, exposure of manpower to the WWII draft, or shifts to war production, did not play a big role in determining the effects of the TWI training.

The contribution of this paper is fourfold. First, it contributes to the growing literature on management and firm performance. While recent RCTs have documented large and positive effects on firm performance of management consulting (for example, Bloom et al., 2013a; Bruhn, Karlan, and Schoar, 2018) and mixed effects of management training (McKenzie and Woodruff, 2014; Gosnell, List, and Metcalfe, 2020), the existing evidence is mostly focused on the short term. To the best of our knowledge, only two papers have estimated the long-term impact of management interventions. Bloom et al. (2020) measured the effects of management consulting on the adoption of management practices, although not on financial performance, between seven and nine years after an RCT involving seventeen Indian textile firms. Giorcelli (2019) estimated the effects of management training on the performance of 130 small and medium-sized Italian firms over fifteen years.

While the TWI program was primarily a management training scheme, it also had a consulting component, so our results are related to both of those papers. ${ }^{1}$ Specifically, our paper complements this prior work by (i) investigating the channels that determine the longterm dynamics of management interventions, and (ii) focusing on large businesses. It tracks the effects of management training on firms in the supply chain of trained companies and on other nonapplicant firms. Moreover, it explores complementarities among different areas of management training.

Second, our paper contributes to the literature on personnel and organizational economics. Previous works have shown that a key correlate of both plant and worker productivity is the adoption of human resource management practices (Ichniowski, Shaw, and Prennushi, 1997; Lazear, 2000; Lazear and Shaw, 2007; Gosnell, List, and Metcalfe, 2020), which in turn can be improved by managers' skills (Lazear, Shaw, and Stanton, 2015; Hoffman and Tadelis, 2021). Our paper contributes to these findings by studying the role of human resource management practices (taught via the J-R module) in a large-scale experiment on thousands of firms that operated in different sectors, rather than leveraging data from a single firm or from a few firms in the same industry. Moreover, it corroborates prior suggestive evidence on complementarities between human resources practices and other areas of management (Bloom and Van Reenen, 2011) by exploiting as-good-as-random variation in the type of training received by applicant firms.

Third, this paper contributes to the large literature on spillover effects across firms. Previous

${ }^{1}$ Although the TWI lectures were standardized as a training program, most of the in-class time was spent on student-led discussions on how to apply the J-modules to firm-specific problems. 
works have documented sizable spillover effects determined by the opening of large plants (Greenstone, Hornbeck, and Moretti, 2010; Alfaro-Urena, Manelici, and Vasquez, 2019), technological externalities (Javorcik, Keller, and Tybout, 2008), an increase in trade (Pavcnik, 2002), and worker mobility (Stoyanov and Zubanov, 2012). In relation to management interventions, Bloom et al. (2020) documented the spillover of some positive managerial practices across plants within the same firm. Our paper complements their findings by tracking the flow of managerial knowledge along the supply chain.

Finally, our paper contributes to the literature on the relationship between the U.S. government's wartime economic policies and the post-war economic boom. Existing works have documented that large public investments in manufacturing during WWII did not substantially increase industrialization in the long term (Jaworski, 2017), but had more persistent positive effects on population growth (Koustas and Li, 2019; Fishback and Cullen, 2013), employment, and wages (Garin, 2019). Moreover, Gross and Sampat (2020) shows that large governmentsponsored R\&D programs during WWII impacted both the direction and the location of U.S. inventions after the war. We argue that the publicly funded wartime diffusion of "soft" management technologies, which had a long-lasting effect on firm performance, represented a previously unexplored channel through which government interventions affected the post-war boom.

The rest of the paper is structured as follows. Section 2 describes the origin and development of the TWI program. Section 3 describes the data. Section 4 presents the empirical framework and discusses the identification strategy. Section 5 examines the long-run effects of the TWI program on firm performance and the complementarities among different types of training. Section 6 analyzes the effects of the TWI program on nontrained firms in the economy. Section 7 discusses war-related events and heterogeneous effects. Section 8 concludes.

\section{Historical Background}

\subsection{Set-up of the TWI Program}

From the onset of WWII in September 1939, the Allied forces needed a large amount of war supplies. Many U.S. companies started receiving an increasing number of war-related orders, especially from France and Britain, that were well in excess of their productive capacity (TWI Administration, 1940). As the war escalated, it became apparent that if and when the United States would join the Allies by declaring war, that event would make the situation even more critical. A great fraction of men of working age would then be called up to serve, depriving the workforce of many productive employees.

The U.S. government responded to these concerns by launching the Training Within Indus- 
try program. The TWI program was aimed at providing in-plant management training to U.S. war contractors to increase their production and productivity and to teach them how to make new workers productive in the shortest possible amount of time.

The TWI administration was established in August 1940 by the National Defense Advisory Commission (after the fall of France on June 22, 1940) and was later moved to be under the jurisdiction of the newly established War Manpower Commission (WMC) on April 18, 1942. It remained under the supervision of the WMC until it ceased all operations in September 1945 after Japan's surrender. Overall, the TWI maintained the same organization and functioned under the same leadership throughout its existence, in spite of the shift in jurisdiction in 1942 (Dooley, 1945; p. 106).

The TWI program was set up to operate as a decentralized service. In September 1940, the TWI administration divided the U.S. into twenty-two geographical districts (Figure 1 and Table A1). These districts were centered around established industrial areas, which often crossed state boundaries. Each of them had its own headquarters and was headed by a District Director. ${ }^{2}$ To better reach peripheral areas, the TWI administrators decided to decentralize the program even further and divided each district into smaller geographical units, which we call subdistricts, headed by resident representatives. In total, they created 364 subdistricts (Dooley, 1945; p. 7).

While the TWI program had the ambitious goal of offering management training to all U.S. war contractors, a limited budget and a lack of manpower made this initial plan not viable. More importantly, the TWI administration soon realized that the success of the program hinged on the full support of trained firms' top management. As a result, the policy of the program became to train only firms that wanted to be part of it (TWI Administration, 1944). Accordingly, the TWI program established different application windows. ${ }^{3}$ The only condition for applying was that firms had to have a war contract with the U.S. government. Moreover, firms could apply only once. In total, there were ten application windows: one each in the years 1940, 1941, and 1945, two each in 1943 and 1944, and three in 1942. Within each subdistrict and application window, eligible firms that applied received the TWI training in the order in which they had applied.

\footnotetext{
${ }^{2}$ Most district directors were business executives who volunteered their expertise to the program. They were called "dollar-a-year" men, since they worked for free for the TWI. In addition to the directors, the TWI program was run by men and women with extensive business experience who temporarily left the private sector, hence, the title of training "within industry."

${ }^{3}$ Each window was closed when a target number of firms to be trained in each district was reached. However, as outlined in Section 3, even these limited targets were often overly optimistic and many applicant firms ended up without training due to lack of resources.
} 


\subsection{Content of the TWI Management Training}

The TWI training was divided into three so-called J-modules, as follows (TWI Administration, 1944): ${ }^{4}$

- Job-Instructions (J-I): This module gave supervisors "practice in how to break in men on new jobs." As a result, trained firms started establishing standard procedures for operations, improving lighting, enhancing job safety measures, keeping the factory floor tidy to reduce accidents and facilitate the movement of materials, performing regular maintenance of machines, and recording the reasons for breakdowns. Overall, this module improved the factory operation practices described in Bloom et al. (2013a). ${ }^{5}$

- Job-Relations (J-R): This module gave supervisors "practice in how to promote teamwork." Firms trained in J-R started relying more heavily on performance-based incentive systems for workers and managers, investing more in on-the-job training, and defining more precisely job descriptions and responsibilities; one major result was a decrease in worker complaints and strikes at these firms. Overall, this module acted upon the practices related to human resources described in Bloom et al. (2013a).

- Job-Methods (J-M): This module helped supervisors "simplify and improve methods of doing a job." Firms trained in J-M learned to constantly innovate and improve their business processes. For example, they started managing their inventory more efficiently, improving production planning, and tracking production to prioritize customer orders by delivery deadline. After the end of WWII, they became more likely to develop a marketing research unit and to introduce new product lines. This module mainly operated on the inventory control and sales and order practices described in Bloom et al. (2013a).

The TWI program was initially thought of as a combination of management consulting and training. However, almost immediately after its implementation in 1940, the TWI administration realized that it lacked the resources to provide effective consulting tailored to the individual needs of each war contractor. As a result, for the whole duration of the program, the TWI

${ }^{4}$ In designing their intervention, the leaders of the TWI service adapted to the 1940s context a popular training program used during WWI. In 1917, the Emergency Fleet Corporation of the United States Shipping Board initiated a training program to increase the number of shipyard workers tenfold. To do so, they hired Charles R. Allen, a vocational instructor from Massachusetts. Allen developed a four-step system for training new workers - Show, Tell, Do, Check - as documented in his 1919 book The Instructor, The Man and The Job. This four-step methodology formed the basis for the TWI program developed over twenty years later (Huntzinger, 2005).

${ }^{5}$ When this program was exported to Japan after the end of WWII, this module was split into two components: one was related to standard procedures for operations and maintenance of machines; the other one, called Job-Safety (J-S), focused on workers' safety. 
administration focused primarily on preparing the instructors for in-plant training (Dooley, 1945; p. 16).

The content of the J-modules was constant across all trained firms and formalized in training manuals that the instructors had to follow closely. This standardization was considered a necessary step to ensure the quality of the TWI training and to allow an understaffed organization to serve a vast group of war contractors. In spite of their rigid format, the Jmodules were designed to incorporate the specific challenges faced by each trained firm. The first lecture of each J-module was a supervisor-led demonstration that had the goal of sharing how bad habits could improve by following the core concepts of TWI training. All the following meetings were a combination of formal lectures and "student presentations," in which the workers under training were asked to show how they could apply the TWI teachings to their job (Dooley, 1945; p. 32).

In short, each J-module had been designed to share at least three key characteristics. First, the content was basic and easily learned. Instead of introducing novel concepts, the J-modules were based on accepted principles taught in an effective way. ${ }^{6}$ Second, the program limited the time dedicated to instructors' lectures in favor of practical demonstrations in which the workers could learn by doing. Third, the J-modules intended to ignite a virtuous cycle of improvements within trained firms by stressing the importance of disseminating the TWI trainings to all workers of the firm and by teaching how to apply the scientific method in approaching current and future challenges (Dooley, 1945; p. 41).

\subsection{Implementation of the Training}

In addition to designing the content of the J-modules, the main responsibility of the TWI administration was the training of the instructors who delivered the TWI program to the plants of applicant firms.

Most instructors were men and women with extensive business experience who were sent by their employers to volunteer for the TWI program either part-time or full-time (Dooley, 1945; p. 4). Others were paid staff already working for a government agency. In spite of their different backgrounds, prospective instructors were selected based on their prior expertise in business and teaching.

Upon recruitment, candidates had to attend a "TWI institute," a fifty-hour course, to become an instructor; they were taught by a TWI staff member either in their district of

${ }^{6}$ As stated by the Director of the TWI program, "There is nothing new about TWI programs - they are built on accepted principles. The only new thing is that something was done about getting them used." (Dooley, 1945; p. ix) As an example, upon completion of the program, trained workers received an instruction card to keep in their pockets with the main takeaways of the modules they had attended (Figure A1). 
residence or in Washington, DC. During the first part, candidates had to attend a full J-module. The second part was divided between lectures on the fundamental concepts of a J-module and practice in teaching the course (Dooley, 1945; p. 202).

Although the original plan was to prepare well-rounded instructors able to teach all three Jmodules, the urgency needed to reach war contractors quickly induced the TWI administration to form training specialists. As a result, each instructor was trained to teach only one J-module (Dooley, 1945; p. 58). After being certified, TWI instructors usually returned to their subdistrict of residence where they visited participating firms (often including their employer) — in the order of those firms' applications - to teach the J-module in which they had been trained. After volunteering in a single subdistrict and application window, they returned to their previous employer to resume their regular job.

In each firm, the TWI training targeted managers, line executives, supervisors, and other employees with "functional responsibility for planning of training" (Dooley, 1945; p. 17). In each plant of the participating firms, the instructors delivered their J-modules to groups of at most ten workers each. Training one group in one module required five meetings of two hours. Most applicant firms had hundreds of managers and supervisors who were slated to received the training. Therefore, the need to create small groups of at most ten workers implied that the delivery of a J-module could take weeks or even months within each firm. In total, 1,750,650 workers were trained in at least one J-module between 1940 and 1945 (Dooley, 1945; p. 126).

Once the last group of targeted employees had attended the training, firms had to pick at least one representative who acted as a point of contact between the firm's top management and the TWI program. The TWI administration used firms' representatives to check on the continuing adoption of TWI criteria and to collect post-training data on firm performance (Dooley, 1945; p. 166).

The historical accounts indicate that all J-modules were a resounding success. For example, an electric manufacturing company recorded a 50-percent decrease in defective products within one month of the delivery of the J-I module. A steel company that received the J-R training reported a 54-percent decrease in complaint cases, which induced its grievance committee to change the meeting schedule from three times a week to three times a month. A warehouse that received the $\mathrm{J}-\mathrm{M}$ module documented the introduction of an improvement in the operation of wrapping large rolls of cloth that resulted in a 48-percent decrease in man-hours (TWI Administration, 1944). Our analysis will investigate the effects of the program using a more systematic approach, as outlined in Section 4. 


\section{Data}

We collected and digitized several types of data on the firms that applied to the TWI training. We matched separate datasets using firm name, municipality, and state. What follows is a description of these data sources and key summary statistics. Additional details on the data collection process and the definitions of the variables can be found in Appendix B.

\subsection{Firm-Level Government Records During WWII}

We started our data collection by identifying all firms that were eligible to participate in the TWI program. Because the only application requirement was that firms had to be war contractors located in the United States, we retrieved the list of eligible companies from the tabulation of war supply contracts published by the Civilian Production Administration in 1946. ${ }^{7}$ This dataset includes information on all contracts for war supplies worth at least $\$ 50,000$ and awarded between June 1940 and September 1945. By restricting the sample to war contractors based in the United States, we obtained a list of 25,393 companies eligible to participate in the TWI program.

We then used the monthly records of the TWI Service - compiled between August 22, 1940, and September 19, 1945, and stored at the NARA Archives - to identify the firms that applied to the TWI program. Out of 25,393 eligible firms, we found applications from 11,575 companies. For each application, the monthly records indicate the application date, the district and subdistrict in which the applicant firm was located, whether it eventually received the TWI training, in which of the J-modules it was trained, and the year in which each module was delivered.

Out of 11,575 applicants, 6,056 were eventually trained in at least one J-module. Among them, 62 percent got two J-module trainings, 24 percent got one J-module training, while the remaining firms received all three J-module interventions (Figure 2, Panel A). The bulk of the TWI training was carried out between 1943 and 1945, when the U.S. involvement in the war was most intense. Only 8 percent of trained firms received a J-module intervention between 1940 and 1942, while the other firms were trained starting in 1943 (Figure 2, Panel B).

From the NARA Archives, we also collected data from the plant-level surveys that the TWI administration conducted in treated firms before and after the training. Specifically, the surveys indicate whether a plant was performing each of eleven managerial practices linked to the teachings of the TWI program before the start of each J-module training, three months after the TWI training, and then each year thereafter until 1945.

Finally, we collected information on the workforce composition of applicant firms by digitiz-

${ }^{7}$ Dmitri Koustas kindly shared the digitized version of this dataset with us (Koustas and Li, 2019). 
ing the Selective Service's so-called replacement schedules, accessible at the NARA Archives. After Executive Order 9279 of December 5, 1942, firms in which at least one worker had been drafted had to submit a replacement schedule to their regional Bureau of Manpower Utilization. In these documents, firms described the composition of their labor force, specifically indicating the share of African-American workers and of women, as well as the average years of education and age of all their employees. Moreover, they had to propose a replacement for each drafted worker and indicate how long it would take for the new workers to become fully productive. ${ }^{8} \mathrm{We}$ used this information to determine the labor force composition, as well as the share of drafted employees, of each firm between 1941 and $1945 .{ }^{9}$ Finally, firms had to indicate the name of the companies with which they had an existing contract, as well as the list of products bought from and sold to them. We used this information to identify the TWI applicants' upstream and downstream firms, as described in greater detail in Section 6.1 and Appendix B.

\subsection{Data on Firm Performance}

We constructed a panel dataset of firm outcomes between 1935 and 1955 using information from the annual reports collected by the Mergent Archives. Specifically, we relied on the Historical Annual Reports, a collection of over one million corporate documents covering more than 100 years. ${ }^{10}$ For each firm in our sample, we searched the database of Mergent's historical annual reports available at the University of California, Irvine library, using firm name, municipality, and state. We then digitized the information contained in the documents in order to link data on firm performance to the other data sources.

We were able to find a match for all the 11,575 applicant firms. Moreover, we retrieved information on 11,536 of the 13,857 nonapplicants in order to investigate the spillover effects of the program on nonparticipating firms (Section 6.2). ${ }^{11}$

The annual reports are a very rich source of information. The balance sheets report, among other variables, the value of inventory, current assets, investments, and capital. The income statements often include information on spending in several areas, such as maintenance and repair of machinery, worker injuries, and on-the-job training. We used these variables to create measures of firm performance, such as sales revenues, productivity, and profitability, and to

8 Through the replacement schedules, they could also ask for draft exemptions for some categories of their workers. Managers were usually deferred "in support of national health, safety, or interest" (category II-A).

9 While the replacement schedules started being submitted in 1942, the first schedule contained data on both 1941 and 1942.

${ }^{10}$ https://www.ftserussell.com/data/mergent-archives.

${ }^{11}$ We believe that the lower matching rate among nonapplicants is due to their smaller size. Even though there is not a formal threshold on firm size in order to be included in the Mergent's Historical Annual Reports Collection, in practice publicly traded firms, firms issuing bonds, and larger firms are more likely to be included because it is easier to retrieve their financial information. 
estimate the adoption of various managerial practices (for more details, see Appendix B).

\subsection{Characteristics of Applicant Firms}

In 1939, the year before the TWI program started, applicant firms had, on average, six plants and $\$ 191.78$ million in sales (in 2020 USD), and had been in operation for eight years (Table 1, column 1). They were fairly heterogeneous in terms of employment: while the average number of employees per firm was 1,038, it ranged from a low of 543 to a high of 11,283 workers. Out of all applicant firms, 86 percent were operating in the manufacturing sector, 9 percent in transportation, 3 percent in agriculture, and 2 percent in service. ${ }^{12}$ Between 1940 and 1945, they were awarded 0.68 war contracts per year with an average value of $\$ 25$ million. Moreover, all characteristics were perfectly balanced between trained and nontrained applicants at baseline, a fact that we will explore more in Section 4 (Table 1, column 7).

At least for the manufacturing sector, it is possible to compare the applicant firms to the average U.S. firm using data from the 1939 Manufacturing Census. ${ }^{13}$ The applicant firms included 60,521 manufacturing establishments, equal to 9.8 percent of all U.S. manufacturing establishments reported in the 1939 Manufacturing Census. Moreover, they employed 12,018,503 workers, which is equal to 40 percent of the total U.S. manufacturing labor force in 1939. In short, the average number of employees per establishment was equal to 49 in the 1939 Manufacturing Census and to 199 in our sample.

In spite of their large size, applicant firms did not appear to be well managed. For example, inventory accounted for more than 80 percent of current assets, indicating that these firms were not proficient in production planning. Interestingly, the poor management of inventory was one of the main bad practices highlighted by Bloom et al. (2013a). Moreover, expenses for workers' injuries were higher than spending for performance-based bonuses, suggesting that these firms were more likely to react to problems instead of setting up systems to reward positive behavior. Finally, it should be noted that all these firms suffered major disruptions from WWII: 57 percent of them had to start producing products in a different 2-digit SIC code and, on average, 23 percent of their workers were drafted and ended up leaving their jobs. To summarize, in spite of their large size and high sales, several pieces of evidence indicate that the TWI applicants could have greatly benefited from management training.

\footnotetext{
${ }^{12}$ The information on the firm's sector is not included in the annual financial reports. To retrieve this piece of information, we imputed to each firm the 3-digit SIC codes - specifically, the classification published in 1939 - associated with the firm's products listed in their replacement schedule in 1941 (see Appendix B).

${ }^{13}$ We used data from the 1939 Manufacturing Census that James Lee digitized and kindly shared with us (Lee, 2015).
} 


\section{Identification Strategy}

\subsection{Baseline Specification}

We estimate the effect of receiving TWI training on firm performance with the following difference-in-differences event-study equation:

$$
\mathrm{y}_{i \tau}=\sum_{\tau=-5}^{10} \beta_{\tau}\left(\mathrm{TWI}_{i} \cdot \text { Years after } \mathrm{TWI}=\tau_{i \tau}\right)+\gamma \cdot \mathrm{TWI}_{i}+\eta \cdot \mathrm{App}_{i}+\delta_{c s \tau}+\epsilon_{i \tau}
$$

where the dependent variable, $\mathrm{y}_{i \tau}$, is one of several key performance metrics, such as logged sales, total factor productivity (TFP), and return on assets (ROA) of firm $i$ in period $\tau .{ }^{14} \mathrm{TWI}_{i}$ is an indicator that equals 1 if firm $i$ received the TWI training. Years after TWI $=\tau_{i \tau}$ is a dummy equal to 1 when a calendar year is $\tau$ years before or after the year in which firm $i$ received its first TWI training. The excluded year is $\tau=-1$. The regression controls for the application date to the program $\left(\mathrm{App}_{i}\right)$ because it may be correlated with unobservable characteristics affecting firm performance. ${ }^{15}$ Specifically, we include fixed effects for the application window in which firm $i$ submitted its application and for the number of days between the opening of the application window and the application date. County $c$, sector $s$, and period $\tau$ fixed effects $\delta_{c s \tau}$ control for nonlinear variation in outcomes over time and within sectors and counties. Standard errors are clustered at the subdistrict and application-window level.

Unless otherwise specified, the sample contains a balanced group of firms that were always active between period -5 and period $10 .{ }^{16}$ Finally, because equation (1) is an event study, we need to impute values of Years after TWI $=\tau_{i \tau}$ to applicant firms that never received any training. To this end, we assume that they would have been treated contemporaneously with the first trained firm in their subdistrict and application window. However, our results do not crucially depend on this imputation. In Section 5.1, we show that alternative choices for the timing assigned to nontrained applicants generate similar findings.

\footnotetext{
${ }^{14}$ TFP is calculated using the methodology proposed by Gandhi, Navarro, and Rivers (2020) and the estimated factor weights are reported in Table B2. The results are robust to alternative TFP calculations (Figure A5). ROA is computed as the ratio between profits and fixed gross assets. Appendix B includes a longer discussion of the construction of all variables and more details on the calculation of TFP.

${ }^{15}$ For example, early applicants might have been quicker in recognizing the value of the TWI program and therefore might have been better managed even before the intervention.

${ }^{16}$ In Section 5.1, we show that estimating equation (1) on all available firms, and therefore including those that entered the sample after the first period or exited before the last, leads to qualitatively similar findings.
} 


\subsection{Tests of the Identification Strategy}

In our main specification, each coefficient $\beta_{\tau}$ captures the effect of the TWI program between period $\tau$ and -1, compared to firms operating in the same sector that applied to the program on the same date and from the same county, but which did not get any training. The identifying assumption is that, conditional on nonlinear trends correlated with county-sector pairs and the application date, the performance of firms with and without TWI training would have been on parallel trends in the absence of the TWI program. While the identification assumption cannot be tested directly, here we discuss four pieces of evidence that corroborate our identification strategy.

As it is standard for difference-in-differences regressions, we start by testing whether firms with and without TWI training were on parallel trends before the beginning of the intervention. We estimate equation (1) using only data from the five periods before the start of the TWI training. The estimated coefficients are all precisely estimated zeros. Therefore, this finding clearly rejects the hypothesis that firms with and without TWI training experienced different pre-TWI trends in their sales, TFP, and ROA (Figure A2, Panels A-C). The results remain unchanged if we compute the pre-TWI trends separately for any combination of J-modules, instead of pooling all trained firms in one group (Figure A2, Panels D-F).

Even if trained and nontrained firms followed parallel pre-TWI trends, the TWI administration might still have chosen to offer their free training to the contractors that were more important for war production, for instance on the basis of their large size or the value of war contracts they received. Therefore, as a second piece of evidence, we show that firm characteristics in period -1, the year before the start of the program, do not predict the probability of receiving the training. Specifically, we regress the dummy variable $\mathrm{TWI}_{i}$ on fifteen different variables, as well as fixed effects for application date and county-sector pairs. ${ }^{17}$ We then test the joint significance of these firm variables. The $p$-value associated with this test is 0.32 and therefore fails to reject the hypothesis of no correlation between the training and firm characteristics (Table 2, Panel A, column 1). Similarly, we can replace the dependent variable with several indicators for the different combinations of J-modules received by trained firms (for example, only J-R vs. J-R and J-M). The test of joint significance fails to find any correlation between different types of training and baseline firm characteristics (Table 2, Panel

\footnotetext{
${ }^{17}$ The regressors, all measured in period -1 , are: the logs of sales, value added, number of employees, number of plants, foundation year, the value of inventory, capital, current assets, investments, number of workers' strikes, monetary compensation for workers' injuries, performance-based bonus payments, number of subsidiaries, as well as distance to the nearest railroad station and distance to the nearest port. Adding the inverse hyperbolic sine function of the number and value of government contracts makes some observations drop due to collinearity, but leads to the same finding of zero correlation between firm characteristics and training (Table 2, Panel B).
} 
A, columns 2 to 8). Finally, we show the same lack of correlation between the TWI training and firm-level variables even when we split the sample by year of training (Table A2, Panel A). Overall, these findings indicate that the TWI administration did not favor applicant firms with better preexisting characteristics, not even in the last stages of WWII when the need to increase production became more pressing.

Next, we show that the TWI administration did not choose to favor firms that were located in the most industrialized or economically developed areas of the United States before the start of the program. In fact, the baseline characteristics of the counties in which applicant firms were located do not predict the probability of receiving the training. We regress the variable $\mathrm{TWI}_{i}$ on fourteen county-level variables from the 1940 Census, imputed to each applicant firm based on its location, as well as fixed effects for application date and subdistrict-sector pairs. ${ }^{18} \mathrm{~A}$ $p$-value of 0.48 indicates that the null hypothesis of zero correlation cannot be rejected (Table 2, Panel C, column 1). Moreover, a similar exercise using county characteristics from either the 1920 Census or the 1930 Census confirms this finding, which rules out the hypothesis that the previous result depended on the fact that the Great Depression had eroded much of the cross-county variation in economic outcomes (Table 2, Panels D-E, column 1). We obtain the same findings if we replace $\mathrm{TWI}_{i}$ with indicators for different combinations of J-modules (Table 2, Panels C-E, columns 2-8). Finally, as shown for firm-level characteristics, we do not find any correlation between county variables and training even when we break down applicant firms by training year (Table A2, Panels C-E). These results show that the coefficients of the TWI training did not conflate differential post-WWII economic trends between richer and poorer U.S. counties.

As a last piece of evidence, we show that there is no autocorrelation within subdistricts in the share of trained firms (Table A3). This finding rules out the possibility that the TWI administration favored over time applicant firms located in certain subdistricts (even though these areas were not necessarily more developed at baseline, as shown in the previous paragraph).

\subsection{Assignment of Instructors}

At this point, it would be natural to wonder why, after controlling for application date and county-sector pairs, the delivery of the training was essentially as good as random. We argue that this was due to the way in which different types of TWI instructors were assigned to subdistricts and application windows, combined with several constraints on resources and personnel that

\footnotetext{
${ }^{18}$ The regressors are: log number of manufacturing establishments, log number of manufacturing employees, $\log$ average manufacturing wage, log total expenses in manufacturing, log of the manufacturing value added, log value of manufacturing production, farms per capita, unemployment share (available only in 1930 and 1940), $\log$ population, population per square mile, share of male residents, share of African-American population, share of urban population, share of illiterate population (available only in 1920 and 1930).
} 
the TWI administration faced throughout its existence.

The TWI administration would have certainly preferred to send enough instructors to train all war contractors in all three J-modules, but several bottlenecks made this goal unreachable. First, the TWI staff was not large enough to prepare the needed number of TWI instructors for in-plant training. At its peak in July 1944, the TWI administration had only 415 staff members. Moreover, the size of the TWI staff was much smaller during most of WWII and many employees were working only part-time for the program (Dooley, 1945, p. 14). Second, the lack of manpower was compounded by the fact that both the courses to certify instructors and the TWI training itself had to be carried out in small classes of at most ten students, severely limiting scalability. Third, as discussed in Section 2.3, TWI instructors were trained to be specialists who could teach only one J-module. This decision sped up the delivery of the training, but meant that some applicant firms could not receive one or more J-modules because there were not enough instructors who could teach them in their subdistrict and application window. To summarize, a small staff, as well as instructors with inflexible teaching skills, created variation across subdistricts and application windows in the number of firms eventually trained and the type of trainings they received.

We find three results that corroborate the historical accounts. First, within a subdistrict and application window, the share of instructors who could teach a given J-module is positively and strongly correlated with the probability that firms were trained in the same J-module (Table C1). For example, firms located in subdistrict and application windows in which most TWI instructors could teach the J-I module had a 21.5-percentage-points higher probability of receiving the J-I module as the first TWI training, equal to a 119-percent increase from the mean (Table C1, column 1). This effect implies that the allocation of instructors to subdistricts and application windows drove large differences in the type of training received by firms.

Second, the share of instructors who could teach a given J-module is not correlated with the baseline characteristics of firms that applied in the same subdistrict and application window (Table C2, Panels A and B). Similarly, there is no correlation between the share of instructors and the characteristics of counties in 1920, 1930, and 1940 (Table C2, Panels C-E). These two findings indicate that the TWI administration did not take into consideration the preexisting characteristics of applicants and counties before assigning the TWI instructors to a subdistrict and application window.

Third, within a given subdistrict, there is no autocorrelation in the share of instructors who could teach a given J-module (Table C3). This result is consistent with the historical data, which indicate that the TWI instructors were assigned to only one subdistrict and application 
window. ${ }^{19}$ In fact, most instructors could volunteer to the TWI program only for a short length of time before returning to their regular employers. The lack of reassignment across application windows within a subdistrict led to an as-good-as-random assignment of new instructors in every period.

To conclude, our empirical strategy is designed to compare firms that are in the same county and industry and that applied to the program on the same day, but that are located in different TWI subdistricts. In spite of their many similarities (as shown in Section 4.2), these firms could have received different types of TWI training. In this section, we showed that these differences in training are driven mainly by the assignment of TWI instructors to subdistricts and application windows. Moreover, we showed that the assignment of TWI instructors did not depend on the characteristics of applicant firms, the characteristics of the counties, or prior assignments in the same subdistrict. These results are consistent with the idea that the TWI administration did not act strategically in assigning their resources to applicant firms.

Based on these findings, we can modify the baseline equation (1) by instrumenting the training variables with the share of instructors who could teach different J-modules assigned to the subdistrict and application window in which firm $i$ applied to the program. As expected, the IV and OLS estimates are close and lead to the same conclusions (Table C4). Considering that all the available evidence in Sections 4.2 and 4.3 points to the unbiasedness of the OLS estimation of equation (1), we will focus on OLS regressions for the remainder of the analysis due to their higher precision and easier interpretation.

\section{Dynamic Effects of the TWI Program}

In this section, we estimate the dynamic effects of the TWI program up to ten years after the training. In order to show more clearly that each J-module induced changes in different managerial practices, Section 5.1 limits the sample to firms that received either one J-module or no training at all. In Section 5.2, we expand the sample to all applicants, including firms that received two or three J-modules, in order to study complementarity effects among different types of management training.

\subsection{Effects on Firm Performance and Managerial Practices}

Firm exit. We start our analysis by investigating if firms that received the TWI training experienced a lower exit rate than nontrained applicants. First, we estimate the following Kaplan-

\footnotetext{
${ }^{19}$ The strong correlations between instructors and training in Table $\mathrm{C} 1$ corroborate the precision of the data. In fact, the presence of widespread and undocumented reallocation of instructors across subdistricts and application windows would produce substantial measurement error. In this case, we should expect to find a small and possibly insignificant relationship between the original assignment of instructors and the training delivered to firms.
} 
Meier survival function separately for trained and nontrained applicants: $\hat{S}_{t}(t)=\prod_{t_{\tau} \leq t}\left(1-\frac{d_{\tau}}{n_{\tau}}\right)$, where $n_{\tau}$ is the number of firms that survived until time $\tau$ and $d_{\tau}$ is the number of firms that closed down at time $\tau$. Compared with nontrained applicants, firms that received the training experienced a significantly lower exit rate (Figure A3, Panel A). Out of all trained firms, 90 percent survived for at least ten years after the beginning of the TWI program, compared to 64 percent of nontrained firms. The log-rank test rejects the null hypothesis of equality between the two survival functions at the 1 percent of significance. Second, we regress an exit dummy on an indicator for participation in the TWI program, controlling for application date and county-sector fixed effects via the following OLS regression: $\operatorname{Exit}_{i}=\beta \mathrm{TWI}_{i}+\eta \cdot \mathrm{App}_{i}+\delta_{c s}+\epsilon_{i}$, where the dependent variable is an indicator equal to one for firms that dropped from the sample by the tenth year after the start of the TWI program, $\delta_{c s}$ are county-sector fixed effects, and the other variables are defined after equation (1). These estimates indicate that trained applicants experienced a 26-percentage-point lower exit rate by the end of the tenth year after the beginning of the TWI program, corroborating the results of the Kaplan-Meier functions (Table A4).

Firm performance. The estimates of equation (1) indicate that the TWI training had a long-lasting impact on firm performance. Annual sales of trained firms increased by 5.3 percent within one year of the TWI training, compared with nontrained applicants (Figure 3, Panel A). This differential effect reached a peak of 21.7 percent in period eight and then decreased to 16 percent in period ten. The treatment effects on productivity and profitability show monotonic increases in the post-TWI years. Specifically, the TFP of trained firms exceeded the TFP of nontrained firms by between 6 percent in period 0 and 27 percent in period ten (Figure 3, Panel B). Similarly, their ROA increased by up to 11 percent by the tenth year after training (Figure 3, Panel C).

We can further explore the increase in productivity by focusing on the different components of the production function (Table A5). In addition to the aforementioned increase in revenues from sales, we find that trained firms experienced a 1-percent decrease in capital and an 8percent decrease in intermediate goods after the TWI program, compared with nontrained applicants. $^{20}$ These changes are associated with an increase in TFP and explain why TFP increased more than annual sales. Finally, trained firms experienced a 6-percent increase in

\footnotetext{
${ }^{20} \mathrm{~A}$ decrease in the value of intermediate goods used for production is consistent with the nature of the TWI program. One of the main goals of the TWI training was to increase production efficiency in a period in which the overall availability of inputs was scarce. Moreover, better human resource management (especially though the J-R module) decreased the cost of scaling up the workforce. Therefore, trained firms may have replaced externally sourced intermediate goods with internal labor. This hypothesis is consistent with the fact that trained firms experienced an increase in the number of employees (Table A5, column 5) and the number of subsidiaries (Table A6, column 4).
} 
the number of employees, compared with nontrained applicants. This variation contributed to decrease productivity, but it was not large enough to overcome the increase in sales and the decrease in intermediate goods.

At least three things are worth noting about these results. First, since most of the training was carried out between 1942 and 1945 (Figure 2, Panel B), for most trained firms the war ended within three years after the program began. However, the effects kept increasing after period three. We will further explore how war-related factors may have influenced the results in Section 7. Second, the estimation of single-difference event studies indicates that firms with and without training had followed the same, and not just parallel, trends before the TWI program (Figure 3, Panels D-F). This finding reinforces the notion that the delivery of the TWI training was not correlated with preexisting firm conditions. Finally, while the effects of the TWI program are fairly large, their magnitude is either in line with, or smaller than, the effect sizes found in similar studies (Figure A4). For instance, our treatment effects on sales are 4 percentage points smaller than the effects on output found by Bloom et al. (2013a) and at most 6 percentage points smaller than the effects on sales found by Giorcelli (2019). Moreover, they are consistent with the historical records that documented large effects of the program of firm productivity (Section 2.3).

The results are robust to a variety of modifications to the baseline specification and sample (Figure A5). Specifically, we replace county-sector-period fixed effects with either firm and period or with district-sector-period fixed effects. We cluster the standard errors at different levels of aggregation. We also impute values of Years after $\mathrm{TWI}=\tau_{i \tau}$ to nontrained firms using the values of the last, instead of the first, trained firm in their subdistrict and application window. Moreover, we match trained and nontrained firms using different propensity-scorematching algorithms (Table A7).

Next, we investigate how the higher attrition of nontrained firms affected these findings. First, we reestimate equation (1) allowing for firm entry and exit, instead of using a balanced sample (Figure A3, Panels B and C). The treatment effects in the unbalanced sample are larger than the baseline treatment effects in the balanced sample. Second, we bound the treatment effects by hypothesizing extreme cases of attrition. Specifically, the exit regressions indicate that attrition was 26 percentage points lower among trained applicants (Table A4). Therefore, to rebalance the sample, we remove all trained applicants either in the top or bottom quartile of the distribution of sales (Figure A3, Panel D) or TFP (Figure A3, Panel E) in period -1. The two resulting event studies are close to the baseline, indicating that attrition based on initial performance is not able to generate substantial bias in the main results.

Over time, trained firms undertook a number of structural changes that transformed them 
into larger and more complex organizations. Compared with nontrained firms, the number of plants of trained firms increased by 6.4 percent by period ten, the number of their employees by 13.5 percent, the number of their managers by 11.4 percent, and the number of their controlled subsidiaries by 5 percent (Table A6). These findings are consistent with prior work that highlights the positive relationship between productivity and firm size (Syverson, 2011).

From a financial perspective, the TWI training was a success. The direct costs of the program were $\$ 155$ million (in 2020 USD), which implies that the direct costs per trained supervisor were equal to $\$ 88.5 .{ }^{21}$ Obviously, the highest costs were indirect, namely, the opportunity cost of the time dedicated to the program by the employees of participating firms. Trained employees had to spend ten hours to receive the certification in one of the three TWI modules and possibly many more hours to implement the TWI concepts within their firms. Although we do not have data on the time the trained supervisors took to spread the TWI training within their firms, the available evidence suggests that the program was cost-effective for most firms. Assuming a hourly wage for managers and supervisors of $\$ 45$, supervisors would have needed to dedicate at least 3,400 hours or 21 months of their time to the TWI training in order to make the program unprofitable for their firm by the tenth year after training. ${ }^{22}$

Managerial practices. In the last portion of this section, we estimate the heterogeneous effects of different types of managerial training and their relationship with the adoption of specific managerial practices. Specifically, we replace the indicator $\mathrm{TWI}_{i}$ in equation (1) with a dummy variable for each of the three J-modules. As a reminder, supervisors learned how to break in new employees through the J-I module, how to manage human resources through the J-R module, and how to introduce improvements to business processes through the J-M module. The results indicate that all three trainings had positive and permanent effects on sales and TFP, while only J-R and J-M increased the ROA (Figure A6). Moreover, the J-R module had the largest effects on every outcome.

In order to explain the different effects of the J-modules on firm outcomes, we investigate what changes to managerial practices they induced. We start by analyzing data from the plantlevel surveys the TWI administration conducted in each trained firm before the program, three

${ }^{21}$ The direct costs were the sum of $\$ 92.3$ million of appropriations and $\$ 62.5$ million from the U.S. Office of Education to pay the TWI instructors (Dooley, 1945; p. 122). Moreover, 1.75 million supervisors were trained through the TWI program.

${ }^{22}$ The hourly wage of $\$ 45$ (2020 USD) comes from an annual wage of $\$ 5,000$ (1940 USD) for "personnel workers" from the 1940 Occupational Outlook Handbook (https://babel.hathitrust.org/cgi/pt?id=osu. $32435051428019 \& v i$ iew=image\&seq=7). Moreover, compared with nonapplicants, 6,056 trained applicant firms reported higher profits of $\$ 44.2$ million by the tenth year after training. Therefore, $\frac{(\$ 45 / \mathrm{h} * 3,400 \text { hours })+\$ 88.5}{6,056 \text { firms }} *$ 1.75 mil. trained supervisors $\simeq \$ 44.2$ mil. higher profits. 
months after the program, and then each year after training until $1945 .^{23}$ In general, the survey data show a clear relationship between the content of the J-modules and changes in managerial practices (Table A8). The J-I program highlighted the importance of having the workplace properly arranged and ensuring worker safety (Dooley, 1945; p. 33). In the TWI surveys, firms that received the J-I training reported a drop in machine repairs and an increase in the probability of keeping a reliable record of breakdowns after the training, which can explain the increase in output and TFP.

In contrast, firms that received the J-R module became more likely to offer on-the-job training, performance-based bonus schemes, and a process for workers to submit suggestions to higher management. Moreover, they were more likely to formalize the tasks and responsibilities attached to different positions. These changes should have increased labor productivity, which in turn should have increased output and TFP.

Finally, firms that were trained in the J-M module found new ways to cut inefficiencies or increase revenues. They reported a drop in unused inputs, as well as an increased reliance on production planning and marketing activities. The decreased inventory, in turn, reduced capital utilization with positive effects on TFP. Furthermore, better production planning may have reduced bottlenecks, while a higher focus on marketing may have increased the customer base, leading to higher output.

One caveat in the interpretation of these results is that the self-reported nature of the TWI surveys may have pushed firms to overstate the adoption of good managerial practices. To provide additional evidence on actual changes in spending, we can validate the survey data using information from the firms' financial reports (Table 3). Compared with nontrained firms, firms that received the J-I training started spending more for regular maintenance and less for machine repairs and worker injuries. ${ }^{24}$ In contrast, firms trained in the J-R module became more likely to invest in performance-based bonus payments and on-the-job training programs. Moreover, they became less likely to experience worker strikes. Finally, firms that received the $\mathrm{J}-\mathrm{M}$ training decreased their inventory, while they became more likely to increase the number of product lines and to invest in marketing activities. Remarkably, the only changes in the implementation of managerial practices that these firms documented in their financial

${ }^{23}$ The survey data were collected only for firms that eventually got treated. As a result, this analysis cannot include nontrained firms.

${ }^{24}$ The survey data indicate that firms that received the J-I module reported more injuries after the program, while the financial data show that the same firms spent less for worker injuries after the TWI. The two findings may signal that the J-I module induced trained firms to improve both their safety protocols and the reporting of injuries. As a result, trained firms may have started documenting more injury cases, including minor accidents, while experiencing a decrease in the severity of injuries. Although we cannot directly test it, this hypothesis is consistent with the historical reports on the effects of the J-I module published in the 1944 J-I manual for TWI instructors. 
statements were related to the specific training they had received, which highlights the critical role played by the TWI training. ${ }^{25}$

In short, all trained firms experienced increases in productivity and profitability, but for different reasons. The fact that firms trained in the J-R module reported the largest treatment effects attests to the importance of human resource management in driving firm performance. This result is consistent with the idea that many management practices do not affect performance directly, but only through the mediation of employees' effort (Bender et al., 2018). In this sense, it is not surprising that improving human resources generated the largest benefits of TWI training.

Finally, as pointed out by Bloom et al. (2020), one of the main reasons why management interventions do not always lead to permanent improvements is that beneficial practices are implemented in the short term, but may be abandoned over time. In our case, however, the adoption of good managerial practices induced by the TWI training lasted throughout the period under consideration, which in turn sustained long-lasting effects on firm performance. In this sense, the evidence from the TWI training is consistent with the "Toyota Way" hypothesis that better management is able to start a "multiplier effect of ongoing further improvements" (Bloom et al., 2020; p. 217).

\subsection{Complementarity among Managerial Practices}

At the core of the "Toyota Way" hypothesis is the idea that managerial practices are complementary. According to this view, the costs of adding new managerial practices fall as others are adopted, allowing firms to continuously improve. This form of complementarity is therefore able to transform a single management intervention into a stream of improvements, the so-called kaizen approach.

So far, testing this hypothesis has proven to be quite challenging. In most papers that study management interventions, the firms studied received a service - either consulting or training - that improved a "bundle" of managerial practices at the same time. These settings prevent the analysis of complementarities, because all participating firms experienced contemporaneous improvements in multiple areas. However, due to the way it was implemented, the TWI program offers a unique opportunity to overcome these common challenges. As noted earlier, some firms received training in only one J-module, while others received training in multiple J-modules. We can therefore test whether receiving training in both areas $x$ and $y$ led to a higher adoption of beneficial practices associated with area $x$, compared with receiving training in area $x$ exclusively.

\footnotetext{
${ }^{25}$ These results, as well as the main findings in Sections 5.2 and 6.1, are robust to different clustering of the standard errors (Table A9) and to corrections for multiple concurrent testing (Table A10).
} 
In the empirical analysis, we replace the indicator $\mathrm{TWI}_{i}$ in equation (1) with a dummy variable for each of the three J-modules. Moreover, for each J-module, we add an indicator that equals one for firms that received that module along with another type of training and we interact it with a Post-TWI $\mathrm{T}_{i \tau}$ dummy. The coefficients of these new interactions measure the additional effect that stems from receiving each module together with another training, compared with receiving each module by itself. If there are no complementarities, the coefficients of these interactions will be small and not statistically significant.

The data indicate that there were moderate complementarities for the J-R and J-M modules, but none for the J-I module (Table 4). Firms that received the J-M training with another module introduced 6.8 percent more product lines and were 2.7 percent more likely to report spending for marketing activities, compared with firms that received the J-M module alone. Firms that received the J-R training with another module experienced 9.6 percent fewer strikes and were 2.6 percent more likely to report spending for on-the-job training, compared with firms that received the $\mathrm{J}-\mathrm{R}$ module by itself. ${ }^{26}$

Remarkably, after the TWI program was exported to Japan in the post-WWII period, the JM training became the main inspiration for Toyota's kaizen approach (Dinero, 2005; p. 48). It is therefore interesting to observe that the J-M module was one of the two modules that benefited from complementarities, one of the main features that characterize kaizen. Conversely, the lack of complementarities associated with the J-I module is most likely due to the nature of its content. Teaching how to use firm machinery safely and effectively did not seem to become easier with improvements in other areas, possibly because establishing the formal set of rules required by this module was all that was needed.

\section{Effects on Other Firms}

One of the unusual features of the TWI program is the fact that it targeted many large-size firms that accounted for a substantial share of the U.S. workforce in the 1940s. The large scale of the program offers a unique opportunity to study whether management training is able to generate spillover effects on other firms not directly targeted by the intervention. To the best of our knowledge, this is the first study that examines training spillovers across firms systematically.

\subsection{Spillover and Selection Effects on Supply Chain}

We started our analysis by examining whether the TWI training generated spillovers on firms in the supply chain of trained applicants. To do so, we first identified applicants' upstream and downstream firms by combining information on their products with information on applicants'

\footnotetext{
${ }^{26}$ These findings are robust to two alternative specifications (Tables A11 and A12).
} 
products that are available in the replacement schedules. ${ }^{27}$ Overall, we found data on 1,816 upstream and downstream firms linked to 1,572 firms that applied to the TWI program.

Next, we estimate equation (1) using as the dependent variable financial data from these upstream and downstream firms. Moreover, we replace the indicator $\mathrm{TWI}_{i}$ with a dummy variable for each of the three J-modules. This specification allows us to study whether the specific type of training received by an applicant had effects on the practices adopted by nontrained firms in its supply chain.

The results indicate that firms in the supply chain became more productive after trained firms received the TWI training, even though the sales of the former group did not increase (Table 5, Panel A). On the one hand, these results may be due to the fact that these firms were now working with companies that had themselves become more productive. On the other hand, they may indicate that upstream and downstream firms were exposed to the specific J-modules received by the applicant firm with which they had a business relationship.

To test whether there was indeed a spillover of managerial knowledge, we estimate whether firms in the supply chain started implementing the same managerial practices taught to trained companies. Remarkably, we find evidence that each J-module induced upstream and downstream firms to improve the managerial practices related to its content, following the same pattern that we described in Section 5.1. For example, firms in the supply chain of applicants that received the $\mathrm{J}-\mathrm{R}$ training became less likely to experience worker strikes and more likely to report spending for on-the-job training. And firms in the supply chain of applicants that received the $\mathrm{J}-\mathrm{M}$ training decreased the size of their inventory, increased the number of product lines, and became more likely to report spending for marketing activities.

There are four additional things to note about these findings. First, these results apply to both firms that were already in the supply chain of applicants at the time of the TWI training and to firms that entered only after the TWI program (Table 5, Panel B). Second, with the exception of the decrease in inventory, the effect sizes tend to be smaller than the main treatment effects on applicant firms. This is not surprising because spillovers are often smaller than direct effects. Third, the J-I module does not show any evidence of spillovers on the supply chain. This result could be due to its content-which involved basic tasks performed by lower-skilled workers and, therefore, less likely to be discussed by managers working for different firms- or to its smaller direct effects on applicant firms. Fourth, the spillovers associated with the J-M module tend to be larger when the trained firm was operating in the manufacturing sector (Table A13, Panel A). ${ }^{28}$

${ }^{27}$ More details are available in Appendix B.

${ }^{28}$ The results do not depend on two other characteristics of trained firms, that is, the size of the workforce at baseline and the location (Table A13, Panels B and C). 
Finally, we study whether trained applicants became more likely to have better upstream and downstream firms. To do so, we focus exclusively on firms that entered the supply chain of applicants after the TWI program. Then, we regress their characteristics observed in the year before their entry into the supply chain of an applicant on the $\mathrm{TWI}_{i}$ indicator, which is one if the applicant received a form of TWI training. ${ }^{29}$ The coefficients of $\mathrm{TWI}_{i}$ indicate that, after experiencing the TWI program, trained applicants were more likely than nontrained applicants to enter into a business relationship with more productive and larger upstream and downstream firms (Table A14).

Overall, these findings indicate another channel through which the TWI training could have had long-lasting effects on trained firms. After fixing their own internal processes, trained applicants could experience additional improvements by transmitting the key concepts of the TWI program to firms in their supply chain. Interestingly, the TWI program itself emphasized the importance of spreading the J-modules both within and outside the firm in order to maximize the so-called "multiplier principle" of training (Dooley, 1945; p. 6). Consistent with this finding, using modern data from the Census Bureau's Management and Organizational Practices Survey (MOPS), Bloom et al. (2013b) finds that 76 percent of respondents mentioned the supply chain (customers and suppliers) as a source of new management ideas.

\subsection{Spillover Effects on Nonapplicant Firms}

The TWI program was open to all U.S. war contractors, but only 46 percent of them applied. Compared with applicants, nonapplicant firms were on average less productive, had fewer plants and employees, and reported lower sales in 1939, the year before the beginning of the TWI program (Table A15). In spite of these differences, applicants and nonapplicants were operating in the same sectors, had a workforce with similar gender and racial composition, and were equally affected by the war. For example, comparable shares of their employees (23 percent for applicants vs. 20 percent for nonapplicants) were drafted during WWII.

In this section, we use data on nonapplicant firms to answer two questions. First, we investigate whether the TWI training had spillover effects on the nonapplicants located near trained firms. On the one hand, nonapplicant firms could have benefited from spillovers of managerial knowledge. On the other hand, these firms could have been harmed by the improved performance of trained firms. To estimate these effects, we divided the 364 subdistricts into 52 groups of adjacent subdistricts. For each nonapplicant firm, we computed the number of applicant firms located in the same cluster of subdistricts and their average distance from the nonapplicant firm. Next, we regress nonapplicants' economic outcomes on one of these two

${ }^{29}$ These regressions also include fixed effects for district-sector combinations, the application window, and the number of days between the opening of the window and the firm application. 
measures of indirect exposure to the TWI program interacted with period dummies, in which period 0 identifies the modal treatment year within each of the 52 groups of subdistricts. ${ }^{30}$

The results of these regressions indicate the lack of spillovers (Figure A7 and Table A16). Specifically, having a greater number of trained firms nearby had no correlation with the performance of nonapplicants or with their adoption of managerial practices. It is important to note that these findings do not necessarily rule out the possibility that trained firms drew business away from nonapplicants. Given that the U.S. economy was growing after WWII, trained firms might have gained market share at the expense of nonapplicants even without poaching their existing customers.

Second, we investigate what the effects of the TWI program would have been, had it been implemented with a group of firms with characteristics more similar to those of nonapplicants. To do so, we replicate the estimation of equation (1) on a smaller sample of applicant firms that we matched to nonapplicants based on their features in 1939. Specifically, the matching process was based on propensity scores and used a nearest-neighbor algorithm without replacement. The matching variables were the number of plants and employees in 1939, TFP in 1939, distance from the nearest port and railroad station, sector, and fixed effects for the 22 TWI districts. The result is a group of 2,223 applicant firms with features that more closely mirror those of nonapplicants (Table A15, column 6). Estimating the main specification on this sample reveals similar effects on sales and TFP and smaller effects on ROA (Figure A8), which nevertheless remain significant and persistent.

In short, the baseline treatment effect that we estimated in Section 5.1 measures the consequences of training on the average firm that was willing to participate in the TWI program. This result, which is unbiased for voluntary participants, is the one that is more common in the literature on management interventions. In fact, in most cases it is not possible to force firms to open their plants to consultants or trainers. In order to keep attrition low, especially when the sample size is small, many studies need to preselect a group of firms that have shown interest in receiving the intervention. The estimates using the smaller sample of matched applicants provide a better description of the effects of the TWI program on the average war contractor, rather than the more productive and larger average applicant firm. The two sets of estimates remain very close, suggesting that the effect of the TWI program did not significantly depend on the level of firm performance at baseline. ${ }^{31}$

In addition to turning down free training during WWII, there is no evidence that the nonapplicants attempted to implement the TWI concepts during the post-WWII years, even

\footnotetext{
${ }^{30}$ The regressions also include firm and period fixed effects.

${ }^{31}$ We will test this hypothesis directly in Section 7.
} 
though the program was proving effective among trained firms. This fact might be even more surprising if we consider that, after the end of the war, the TWI Foundation (now a private entity) successfully exported the J-modules to 27 countries, including Japan, where they inspired the implementation of lean production (Dinero, 2005; p. 42). Two main reasons could explain low interest for the TWI training in the United States (Dinero, 2005; p. 15).

First, in the post-WWII period, U.S. firms might have perceived external trainers as potentially interfering with their processes and limiting their agency, instead of as a source of help (Breen, 2002; p. 264). All U.S. firms were facing a large increase in domestic demand. Moreover, they were expanding their market share in foreign countries, due to the fact that many foreign factories had been damaged or destroyed during WWII. In this period of economic bonanza, low-productivity firms might have been shortsighted enough to consider training a nuisance. This possible explanation is consistent with the fact that we did not find negative horizontal spillovers and with the fact that U.S. firms refocused on training only when their worldwide dominance was threatened by Japanese products in the late 1970s (Cusumano, 1985).

Second, although the TWI printed materials were available for purchase after the war, U.S. firms that wanted to implement the J-modules could not rely on the TWI administration. The lack of carefully vetted and highly prepared TWI instructors, as well as the absence of any follow-up, were possibly important enough reasons for making a self-taught TWI training likely to be less successful than the original program had been.

\section{War-Related Events and Other Heterogeneities}

In this section, we perform several heterogeneity analyses to show how firms with different characteristics responded to the TWI program. As a general caveat, we cannot usually leverage exogenous variation along the dimensions used for these heterogeneity tests. Therefore, these results should not be interpreted as causal estimates, but as correlations between firm variables and the baseline treatment effects.

Switching to War Production. So far, we have explored mechanisms that are consistent with the "Toyota-way" hypothesis. Complementarities in management practices, as well as vertical spillovers, can explain why the TWI training was able to generate long-lasting results. Here, we test whether the disruptions generated by WWII might have contributed to diminishing the efficacy of the TWI program over time.

We start this analysis by considering the fact that many U.S. war contractors had to change their product lines to produce war items (Section 3.3). This change in production might have made the TWI training less effective. During the TWI in-plant training, workers might have applied the J-modules to solve the challenges they were facing while producing a given war 
item. After switching to a very different peacetime good, these workers might have faced a new set of problems. Although the J-modules were designed to be widely applicable to different situations, it might have been difficult to implement them for different production processes.

To test this hypothesis, we estimate equation (1) separately for firms that did and did not produce war items in different 2-digit SIC codes (Figure A9). As expected, firms that had to switch to different products during the war benefited less from the TWI training. However, the data also indicate that changing to wartime production was not enough to totally erase the effect of the program. Firms that produced items in different 2-digit SIC codes reported significant increases in their sales, TFP, and ROA.

Loss of Human Capital. The draft represented another major war-related disruption to firm processes. More than half of the male population aged 18 to 45 in 1940 (50 million people) served during WWII (Jaworski, 2014). Data from the replacement schedules indicate that all war contractors in our sample lost workers due to the draft, experiencing mobilization rates of their workforce between 13 and 33 percent. Losing experienced workers to the war might have slowed down the application of the TWI concepts within trained firms, due to the higher influx of untrained and inexperienced new hires. We test this hypothesis by estimating equation (1) separately for firms in different tertiles of the distribution of drafted workers (Table A10, Panels A-C).

Firms in the highest tertile, and therefore those with the highest number of drafted employees, experienced a lower increase in sales, TFP, and ROA, but the gap between those and firms in lower tertiles is small. In short, there is no evidence that the draft substantially interfered with the efficacy of the TWI training. This result is not necessarily surprising when we recall that the TWI program was introduced to teach firms how to deal with the challenges raised by the draft.

Relatedly, we can test whether the loss of human capital after the war was responsible for smaller treatment effects. Specifically, we use the names of the top executives that are included in the firms' financial reports to measure the share of top managers leaving the firm between the end of the training and 1955, the last year available in our sample. Between 4 and 73 percent of top executives left their firms in the years after the program. We then estimate equation (1) separately for firms in different tertiles of the distribution of top management's turnover (Table A10, Panels D-F).

The results on sales and TFP indicate that the effect sizes of the program are larger for firms in which more managers stayed within the firm over the first ten post-training years. However, even for firms in the top tertile of management's turnover, the treatment effects are positive, large, and persistent. For ROA, there is not a clear pattern correlated with the turnover of top 
managers. Moreover, there is no differential implementation of managerial practices between firms with a low versus a high share of managers leaving (Table A17).

These results are relevant because they inform the ongoing debate about whether improvements in management accrue to the firm or to individual managers. The fact that our results are only slightly lower among firms with higher turnover of managers indicates that the TWI training was able to create firm-specific "managerial capital" (Bruhn, Karlan, and Schoar, 2010) that remained within the trained firms, even after trained managers left. These findings are different from the ones reported by Bloom et al. (2020), who document a drop in the implementation of good managerial practices when managers leave the firm; and by Huber, Lindenthal, and Waldinger (2019), who find that the loss of managers can harm a firm's profitability.

However, it is possible to reconcile our findings with this prior work. In the TWI context, trained firms were growing after the end of the war, significantly increasing the number of managers in their ranks (Table A6). Therefore, these firms may have been able to retain the benefits of the TWI program by training the large number of newly hired managers on the importance of the J-modules, even if many top executives who were at the firm at the time of the TWI program were leaving. Consistent with this hypothesis is the fact that the TWI program promoted the diffusion of its principles to nontrained workers within the trained firms (the "multiplier effect" discussed in Section 5.1). Moreover, Friedrich (2020) shows that more productive firms are more likely to use internal promotions to hire managers. If this tendency applied to our sample, trained firms would have started relying more heavily on internal talent, already exposed to the TWI training, to replace departing managers.

Relations with the U.S. Government. Here, we test whether the relationship of trained firms with the federal government strengthened after the TWI training. For example, it is plausible to assume that the Department of War might have preferred to assign war contracts to firms that had been trained in at least one J-module. After all, one of the main goals of the program was to make these firms more productive in order to meet the Allies' military needs.

We test this hypothesis by estimating equation (1) with dependent variables that describe the relationship of trained firms with the federal government. We find that the probability of having war supply contracts, their number and value, as well as the value of subsidies given to war contractors after WWII, were not different between firms with and without training (Table A18 and Figure A11). These results show that improved outcomes are not automatically tied to trained firms having tighter economic relationships with the U.S. government. Moreover, the TWI training does not predict higher war-related government spending in a county, reinforcing the idea that the federal government did not use the TWI program as a tool to assign more 
resources (Table A18, Panel D).

Overall, the data reject the hypothesis that the documented improvements in firm performance stemmed from closer ties with the federal government. First, in Section 4.2, we established that the value and number of war supply contracts before the TWI were not correlated with the probability of receiving training (Table 2, Panel B). Therefore, closer government ties before the program cannot explain selection into treatment. Second, in this section, we found that the value and number of war supply contracts did not increase disproportionately among trained firms after the TWI program. Therefore, closer government ties after the program cannot explain differences in sales and productivity between trained and nontrained firms.

Other Heterogeneities. The TWI program is one of the few management interventions that targeted firms operating in different sectors, namely, manufacturing, transportation, services, and agriculture. Therefore, it is interesting to ask whether the benefits of the program differed across fields. The results indicate that firms operating in all sectors experienced significant increases in productivity after training, but manufacturing and service firms saw the largest increase (Figure A12, Panel A). This finding is consistent with the fact the the J-modules were designed with the manufacturing sector in mind.

In the next set of results, we test whether firms in different U.S. Census Bureau regions benefited differently from the TWI training (Figure A12, Panel B). We find that firms in every region experienced similar long-lasting increases in productivity. This finding indicates that our results do not crucially depend on the local economic conditions that firms may have faced during and after WWII.

Next, we test whether the year in which firms received the training affected the efficacy of the program. The overall pattern of treatment effects is similar among all firms that participated in the program, but firms trained earlier experienced more benefits (Figure A12, Panel C). This finding can be explained by the fact that such firms received more followups from the TWI service before it permanently shut down in 1945 .

In addition, we estimate equation (1) separately for firms in different quartiles of the distribution of workforce size in the year before receiving the TWI training (Figure A12, Panel D). The results do not indicate any clear pattern that is correlated with the size of trained firms at baseline. Moreover, we estimate the treatment effects for firms in different quartiles of the distribution of TFP in the year before receiving the TWI training (Figure A12, Panel E). The results indicate that the program was more beneficial for firms that were less productive at baseline. However, all firms, including those in the top quartile of preexisting productivity, experienced large, significant, and long-lasting increases in TFP.

Finally, we show that the effects of the program did not significantly change among firms 
that received more instructors with experience in the private sector (Figure A12, Panel F). These findings suggest that our results are not driven by the specific instructors who provided the training to war contractors. We can conclude that, in line with the goal of the program, the TWI administration was able to standardize the content of the TWI training and to guarantee the same level of quality among all trained companies.

\section{Conclusions}

This paper studies the long-term and spillover effects of management training on firm performance and the adoption of managerial practices, using evidence from the Training Within Industry (TWI) Program. To perform this analysis, we linked newly digitized information on the participation of 11,575 firms in the TWI program to data from twenty years of those firms' balance sheets and income statements. We compare applicant firms that received the training to applicant firms that did not receive any intervention, both of which groups were statistically indistinguishable before the start of the program, and control for nonlinear trends correlated with the application date, sector, and county.

We find that the TWI training had a positive and long-lasting impact on firm performance until at least ten years after its implementation. Moreover, we establish a direct link between the content of the training and the adoption of managerial practices by trained firms. There are several channels that can explain a long-term effect of training on firm outcomes. First, we document the existence of complementarities among different types of training, which implies that receiving more training decreases the costs of improvements in new areas. Second, we find positive spillovers on firms in the supply chain of trained applicants. Third, we document the fact that trained firms were able to retain most of the benefits of the TWI training even after a large share of their trained executives had left the company. Overall, our findings are consistent with the so-called "Toyota-way" hypothesis, which states that management interventions can generate a virtuous cycle of growth within firms.

We argue that these findings are relevant for both firms and policy makers. Firms routinely use internal training to improve the productivity of their workforce (Acemoglu and Pischke, 1998; Konigs and Vanormelingen, 2015). However, the effectiveness of these policies is usually evaluated over a limited time period, on small samples, usually without randomizing the content of the training, and without evaluating spillovers outside the trained firm (McKenzie and Woodruff, 2014). Our research addresses these open issues by showing that management training can have long-lasting effects, that the content of training matters, and that positive spillovers can take place along the supply chain. Therefore, these factors should be taken into account to ensure the success of management training interventions. 


\section{References}

Acemoglu, Daron and Jörn-Steffen Pischke. 1998. "Why Do Firms Train? Theory and Evidence." Quarterly Journal of Economics, 113(1): 79-119.

Ackerberg, Daniel A., Kevin Caves, and Garth Frazer. 2015. "Structural Identification of Production Functions." Econometrica, 83(6): 2411-2451.

Alfaro-Urena, Alonso, Isabela Manelici, and Jose P. Vasquez. 2019. "The Effects of Multinationals on Workers: Evidence from Costa Rica." working paper, UC Berkeley.

Bender, Stefan, Nicholas Bloom, David Card, John Van Reenen, and Stefanie Wolter. 2018. "Management practices, workforce selection, and productivity." Journal of Labor Economics, 36(S1): S371-S409.

Bloom, Nicholas and John Van Reenen. 2007. "Measuring and Explaining Management Practises across Firms and Countries." Quarterly Journal of Economics, 122(4): 1341-1408.

Bloom, Nicholas and John Van Reenen. 2011. "Human resource management and productivity." In Handbook of Labor Economics. Vol. 4, , ed. David Card and Orley Ashenfelter, 1697-1767. Elsevier B.V.

Bloom, Nicholas, Aprajit Mahajan, David J. McKenzie, and John Roberts. 2020. "Do Management Interventions Last? Evidence from India." American Economic Journal: Applied Economics, 12(2): 198-219.

Bloom, Nicholas, Benn Eifert, Aprajit Mahajan, David Mckenzie, and John Roberts. 2013a. "Does Management Matter? Evidence from India." Quarterly Journal of Economics, 128(1): 1-51.

Bloom, Nicholas, Erik Brynjolfsson, Lucia Foster, Ron Jarmin, and Itay SaportaEksten. 2013b. "Management in America." CES Working Paper 13-01.

Breen, William J. 2002. "Social Science and State Policy in World War II: Human Relations, Pedagogy, and Industrial Training, 1940-1945." Business History Review, 76(2): 233-266.

Bruhn, Miriam, Dean Karlan, and Antoinette Schoar. 2010. "What Capital is Missing in Developing Countries?" The American Economic Review: Papers and Proceedings, 100(2): 629-633.

Bruhn, Miriam, Dean Karlan, and Antoinette Schoar. 2018. "The Impact of Consulting Services on Small and Medium Enterprises: Evidence from a Randomized Trial in Mexico." Journal of Political Economy, 126(2): 635-687.

Cusumano, Michael A. 1985. The Japanese Automobile Industry: Technology and Management at Nissan and Toyota. Harvard University Press.

Dinero, Donald. 2005. Training Within Industry: The Foundation of Lean. Productivity Press; HAR/COM Edition.

Dooley, Channing R. 1945. "The Training Within Industry Report 1940-1945." War Manpower Commission. Bureau of Training.

Fishback, Price and Joseph A. Cullen. 2013. "Second World War spending and local economic activity in US counties, 1939-58." Economic History Review, 66(4): 975-992.

Foster, Lucia, John C. Haltiwanger, and Chad Syverson. 2008. "Reallocation, Firm Turnover, and Efficiency: Selection on Productivity or Profitability?" American Economic Review, 98(1): 394-425.

Friedrich, Benjamin. 2020. "Internal Labor Markets and the Competition for Managerial Talent." working paper, Northwestern University.

Gandhi, Amit, Salvador Navarro, and David A. Rivers. 2020. "On the identification of 
gross output production functions." Journal of Political Economy, 128(8): 2973-3016.

Garin, Andy. 2019. "Public Investment and the Spread of "Good-Paying" Manufacturing Jobs: Evidence from World War II's Big Plants." working paper, UI Urbana-Champaign.

Giorcelli, Michela. 2019. "The Long-Term Effects of Management and Technology Transfers." American Economic Review, 109(1): 1-33.

Gosnell, Greer K., John A. List, and Robert D. Metcalfe. 2020. "The impact of management practices on employee productivity: A field experiment with airline captains." Journal of Political Economy, 128(4): 1195-1233.

Greenstone, Michael, Richard Hornbeck, and Enrico Moretti. 2010. "Identifying agglomeration spillovers: Evidence from winners and losers of large plant openings." Journal of Political Economy, 118(3): 536-598.

Gross, Daniel P. and Bhaven N. Sampat. 2020. "Inventing the Endless Frontier: The Effects of the World War II Research Effort on Post-War Innovation." NBER Working Paper 27375.

Hoffman, Mitchell and Steven Tadelis. 2021. "People management skills, employee attrition, and manager rewards: An empirical analysis." Journal of Political Economy, 129(1): 243-285.

Hsieh, Chang-Tai and Peter J. Klenow. 2009. "Misallocation and Manufacturing TFP in China and India." Quarterly Journal of Economics, 124(4): 1103-1148.

Huber, Kilian, Volker Lindenthal, and Fabian Waldinger. 2019. "Discrimination, Managers, and Firm Performance: Evidence from Aryanizations in Nazi-Germany." Working paper, University of Munich.

Huntzinger, Jim. 2005. The Roots of Lean. Training Within Industry: The Origin of Japanese Management and Kaizen. LeanFrontiers.

Ichniowski, Casey, Kathryn L. Shaw, and Giovanna Prennushi. 1997. "The Effects of Human Resource Management Practices on Productivity." American Economic Review, 86(3): 291-313.

Javorcik, Beata, Wolfgang Keller, and James Tybout. 2008. "Openness and Industrial Response in a Wal-Mart World: A Case Study of Mexican Soaps, Detergents and Surfactant Producers." The World Economy, 31(12): 1558-1580.

Jaworski, Taylor. 2014. "'You're in the Army Now': The Impact of World War II on Women's Education, Work, and Family." Journal of Economic History, 74(1): 169-195.

Jaworski, Taylor. 2017. "World War II and the Industrialization of the American South." The Journal of Economic History, 77(4): 1048-1082.

Konigs, Jozef and Stijn Vanormelingen. 2015. "The Impact of Training on Productivity and Wages: Firm-Level Evidence." Review of Economics and Statistics, 97(2): 485-497.

Koustas, Dmitri and Zhimin Li. 2019. "The Long-Run Effects of Government Spending on Structural Change: Evidence from Second World War Defense Contracts." Economics Letters, 178: 66-69.

Lazear, Edward P. 2000. "Performance pay and productivity." American Economic Review, 90(5): 1346-1361.

Lazear, Edward P. and Kathryn L. Shaw. 2007. "Personnel economics: The economist's view of human resources." Journal of Economic Perspectives, 21(4): 91-114.

Lazear, Edward P., Kathryn L. Shaw, and Christopher T. Stanton. 2015. "The Value of Bosses." Journal of Labor Economics, 33(4): 823-861.

Lee, James. 2015. "Measuring Agglomeration: Products, People, and Ideas in US Manufac- 
turing, 1880-1990." Working paper, Harvard University.

Levinsohn, James and Amil Petrin. 2003. "Estimating Production Functions Using Inputs to Control for Unobservables." Review of Economic Studies, 70(2): 317-341.

Liker, Jeffrey K. 2004. The Toyota Way: 14 Management Principles from the World's Greatest Manufacturer. McGraw-Hill Education.

McKenzie, David J. and Christopher Woodruff. 2014. "What are we learning from business training and entrepreneurship evaluations around the developing world?" World Bank Research Observer, 29(1): 48-82.

Olley, G. Steven and Ariel Pakes. 1996. "The Dynamics of Productivity in the Telecommunications Equipment Industry." Econometrica, 64(6): 1263-1297.

Pavcnik, Nina. 2002. "Trade Liberalization, Exit, and Productivity Improvements: Evidence from Chilean Plants." The Review of Economic Studies, 69(1): 245-276.

Stoyanov, Andrey and Nikolay Zubanov. 2012. "Productivity Spillovers across Firms through Worker Mobility." American Economic Journal: Applied Economics, 4(2): 168-198.

Syverson, Chad. 2004. "Market Structure and Productivity: A Concrete Example." Journal of Political Economy, 112(6): 1181-1222.

Syverson, Chad. 2011. "What Determines Productivity." Journal of Economic Literature, 49(2): 326-365.

TWI Administration. 1940. "Training Workers to Meet Defense Needs." TWI Bulletin \#1.

TWI Administration. 1944. "Management and Skilled Supervision (How the TWI Programs Operate)." TWI Bulletin \#20.

Womack, James, Daniel Jones, and Daniel Roos. 1990. The Machine That Changed the World. New York:Simon and Schuster. 


\section{Figures and Tables}

\section{Figure 1: TWI Districts}

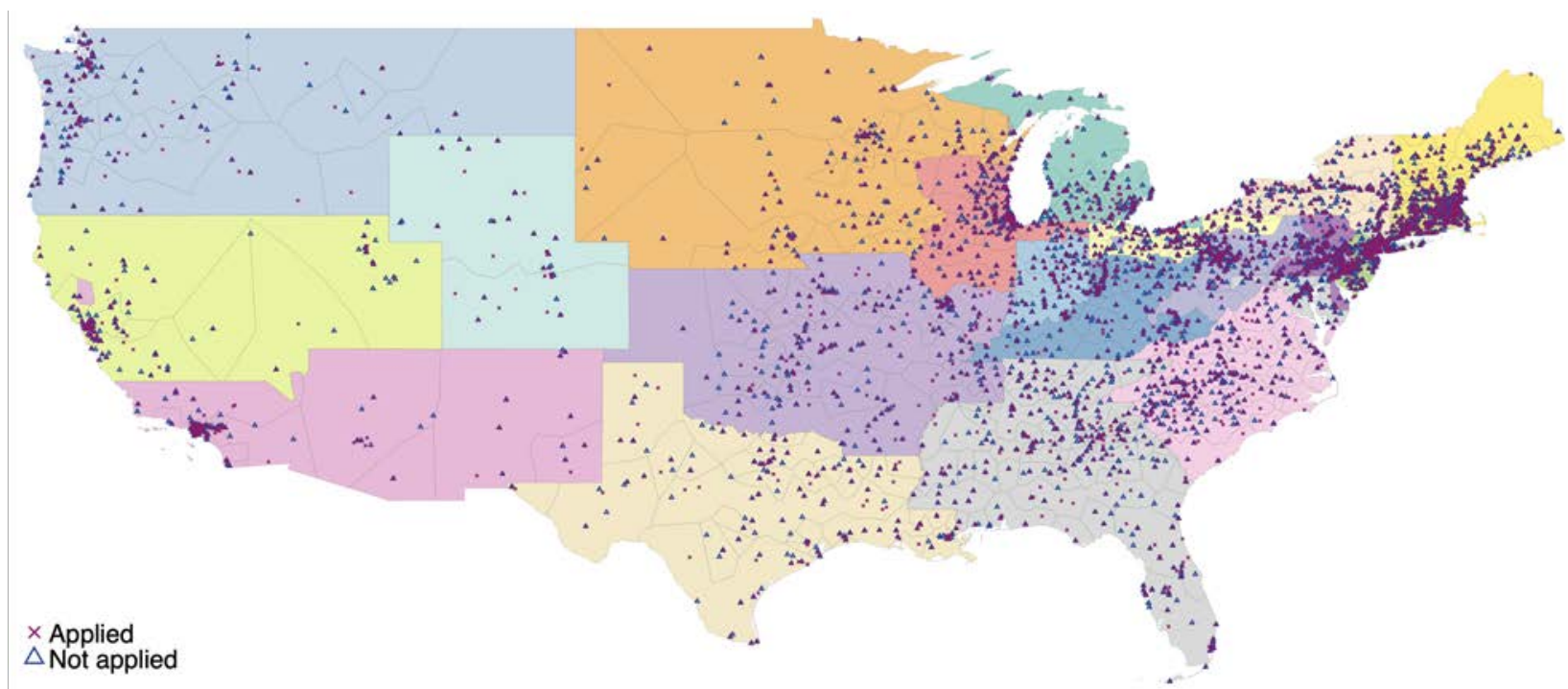

Panel A: Applicant and nonapplicant eligible firms

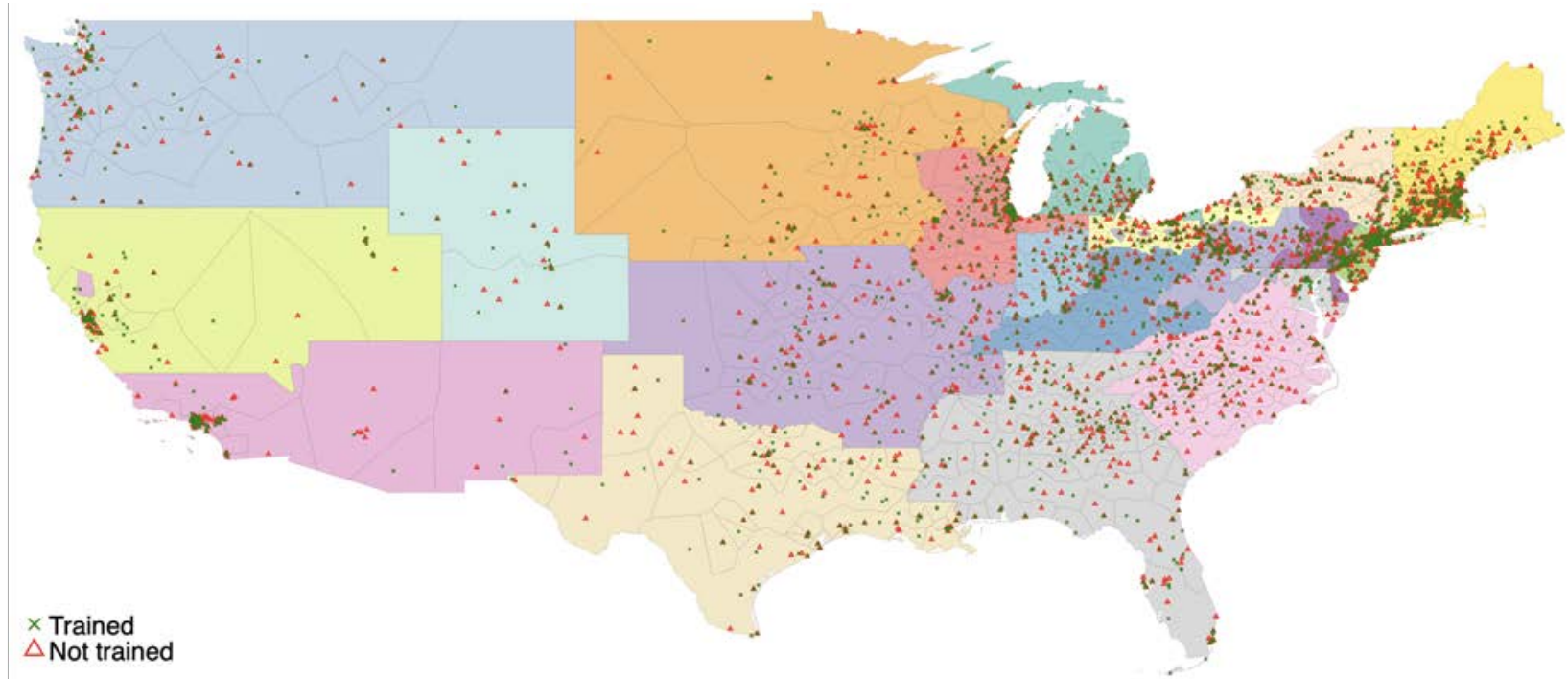

Panel B: Trained and nontrained applicant firms

Notes. Map of the 22 TWI districts. The borders within the 22 districts identify the 364 subdistricts, the level of aggregation at which the program was delivered. Panel A divides 25,393 war contractors between 11,575 firms that applied to the TWI program (purple crosses) and 13,818 firms that did not apply to the TWI program (blue triangles). Panel B divides applicant firms between 6,056 firms that received the TWI training (green crosses) and 5,519 firms that did not receive the TWI training (red triangles). 
Figure 2: Distribution of TWI Training Among Applicant Firms

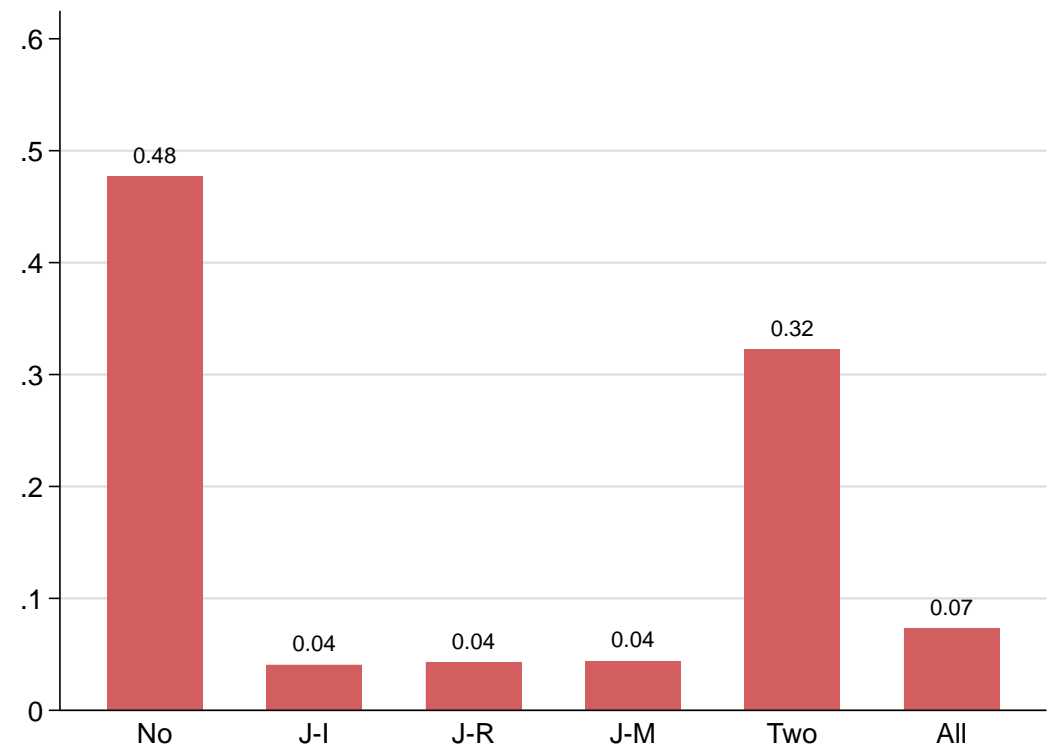

Panel A: Type of TWI training

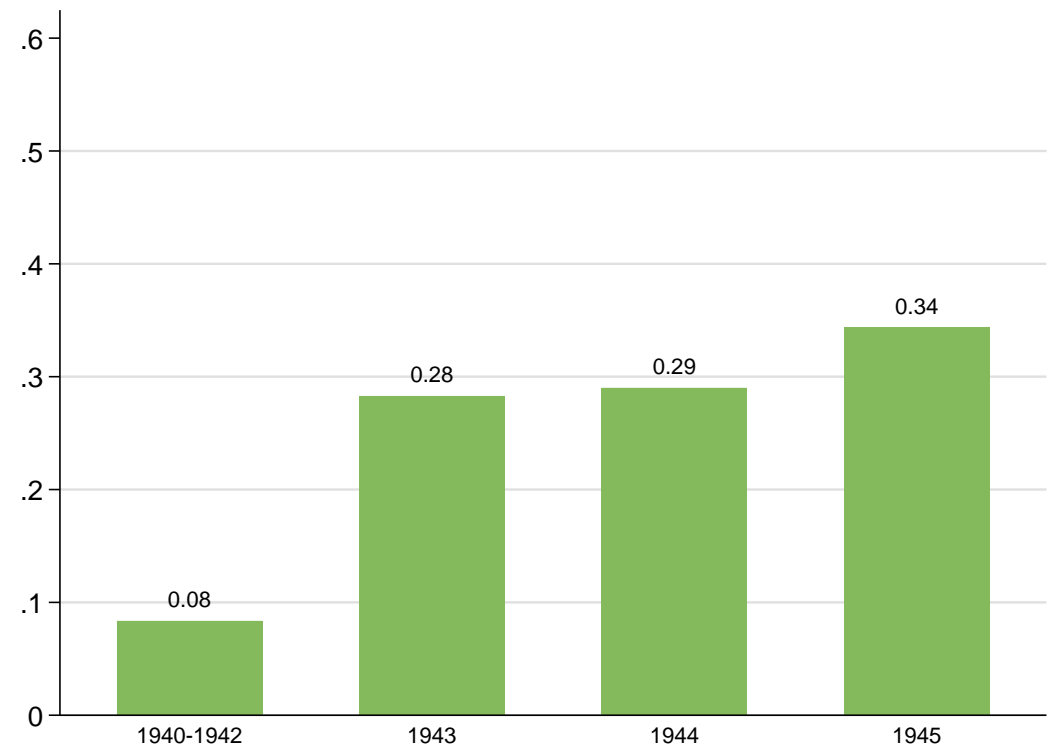

Panel B: Year of training

Notes. This figure shows the distribution of the type of training received (Panel A) and year of training (Panel B) for the 11,575 firms that applied to the TWI program. In Panel A, No=1 for firms that did not get any TWI intervention; J-I $=1$ for firms that received the Job-Instructions training; J-R $=1$ for firms that received the Job-Relations training; J-M = 1 for firms that received the Job-Methods training; Two $=1$ for firms that received two trainings; All $=1$ for firms that received all three trainings. 
Figure 3: Yearly Effects of TWI Training

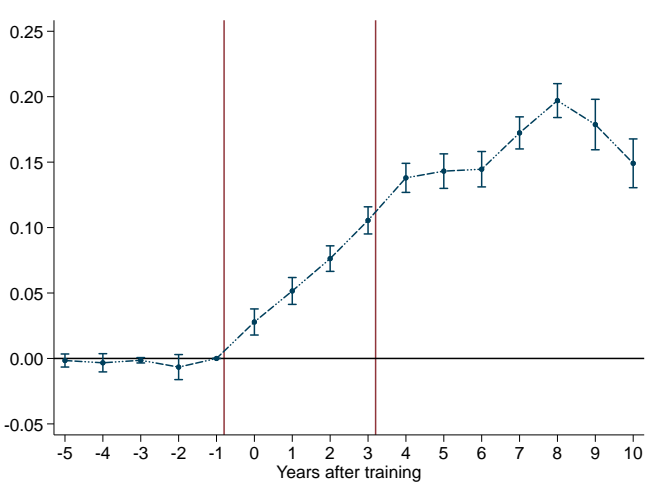

Panel A: Log sales, DID

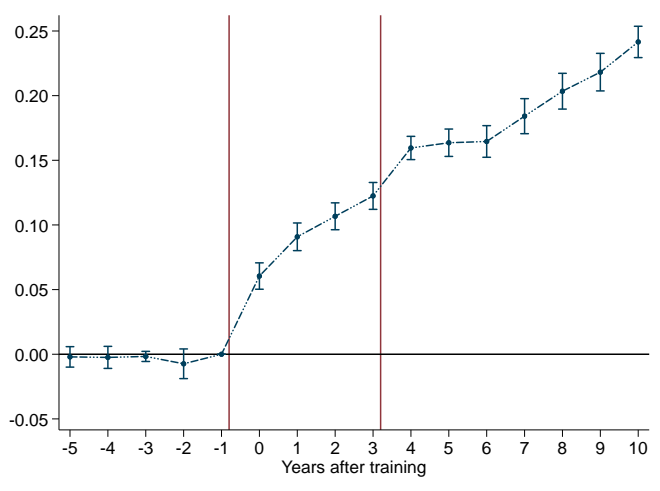

\section{Panel B: TFP, DID}

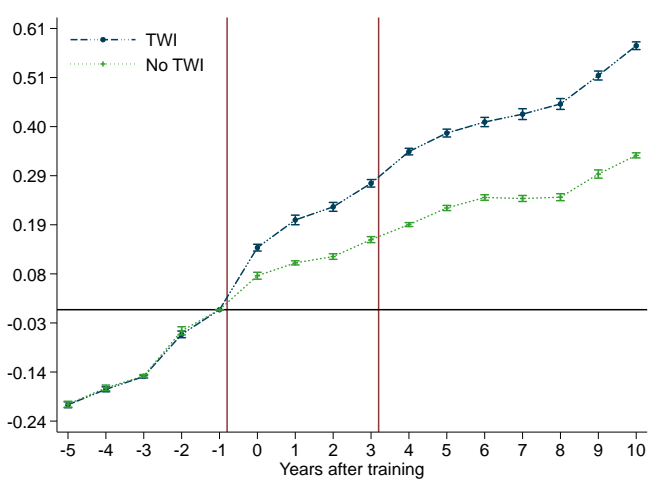

Panel E: TFP, Single Difference

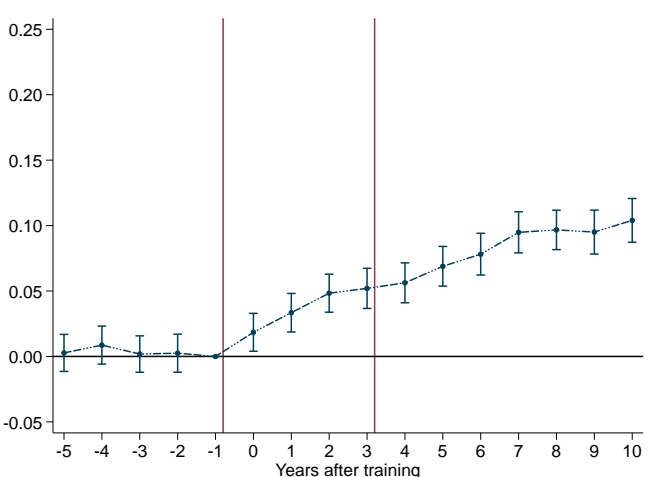

Panel C: Log ROA, DID

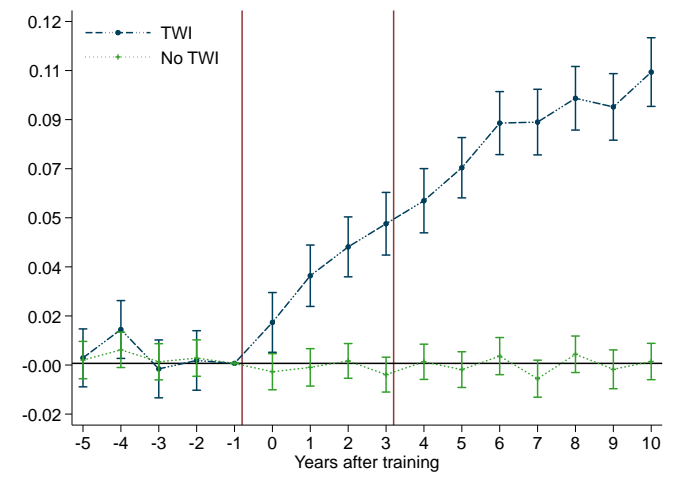

Panel F: Log ROA, Single Difference

Panel D: Log sales, Single Difference

Notes. Panels A-C show difference-in-differences coefficients, while panels D-F show single-difference coefficients. These regressions also include fixed effects for county-sector-period combinations, the application window, and the number of days between the opening of the window and the firm application. The distance from the TWI intervention for the nontreated firms is imputed using the distance from the TWI intervention of the first participating firm in the same subdistrict and application window. The dependent variables are log sales (Panels A and D), TFP computed with the Gandhi, Navarro, and Rivers (2020) method (Panels B and D), log of return on assets (Panels $\mathrm{C}$ and $\mathrm{F}$ ). The sample includes applicant firms that either received only one TWI training or no training at all. The vertical bars denote 95 percent confidence intervals. The first vertical red line identifies the beginning of the TWI program. The second vertical red line identifies the end of World War II for most applicant firms. The standard errors are clustered at the level of subdistricts and application windows. 
Table 1: Summary Statistics for 11,575 Applicants to the TWI Program

\begin{tabular}{|c|c|c|c|c|c|c|c|}
\hline & \multicolumn{4}{|c|}{ All Applicant Firms } & \multirow{3}{*}{$\begin{array}{c}\text { Trained Firms } \\
\text { Mean } \\
(5)\end{array}$} & \multirow{3}{*}{$\begin{array}{c}\text { Nontrained Firms } \\
\text { Mean } \\
(6)\end{array}$} & \multirow{3}{*}{$\begin{array}{c}\text { Difference } \\
p \text {-value } \\
(7)\end{array}$} \\
\hline & Mean & St. Dev. & Min & Max & & & \\
\hline & $(1)$ & $(2)$ & $(3)$ & $(4)$ & & & \\
\hline \multicolumn{8}{|c|}{ Panel A: Data from annual financial statements in 1939} \\
\hline Plants & 6.08 & 1.90 & 3 & 14 & 6.09 & 6.07 & 0.588 \\
\hline Employees & $1,038.32$ & 378.53 & 543 & 11,283 & $1,036.99$ & $1,039.77$ & 0.686 \\
\hline Foundation year & 1931 & 3.73 & 1912 & 1936 & 1930.96 & 1931.05 & 0.229 \\
\hline Agriculture & 0.03 & 0.16 & 0 & 1 & 0.03 & 0.03 & 0.678 \\
\hline Manufacturing & 0.86 & 0.34 & 0 & 1 & 0.86 & 0.86 & 0.746 \\
\hline Transportation & 0.09 & 0.29 & 0 & 1 & 0.09 & 0.09 & 0.400 \\
\hline Services & 0.02 & 0.14 & 0 & 1 & 0.02 & 0.02 & 0.624 \\
\hline Sales & 191.78 & 77.12 & 75.74 & $2,506.72$ & 191.27 & 192.34 & 0.444 \\
\hline Current assets & 18.40 & 8.02 & 5.31 & 170.72 & 18.47 & 18.33 & 0.341 \\
\hline Total assets & 64.45 & 25.79 & 23.03 & 900.89 & 64.40 & 64.51 & 0.808 \\
\hline TFP & 3.87 & 0.49 & 2.68 & 5.02 & 3.87 & 3.86 & 0.316 \\
\hline ROA & 0.03 & 0.01 & 0.01 & 0.09 & 0.03 & 0.03 & 0.010 \\
\hline Inventory & 15.37 & 6.24 & 5.21 & 181.02 & 15.36 & 15.38 & 0.854 \\
\hline Injuries & 10.40 & 5.09 & 2.40 & 139.78 & 10.33 & 10.47 & 0.141 \\
\hline Repairs & 15.37 & 7.26 & 4.04 & 226.42 & 15.28 & 15.48 & 0.134 \\
\hline Bonus payments & 8.27 & 3.97 & 1.97 & 118.42 & 8.22 & 8.32 & 0.176 \\
\hline \multicolumn{8}{|c|}{ Panel B: Workforce data from replacement lists in 1941} \\
\hline Share African-Americans & 0.06 & 0.01 & 0.01 & 0.12 & 0.06 & 0.06 & 0.180 \\
\hline Share women & 0.05 & 0.01 & 0.01 & 0.09 & 0.05 & 0.05 & 0.703 \\
\hline Years of education & 8.51 & 1.36 & 5 & 12 & 8.50 & 8.52 & 0.457 \\
\hline Age of workforce & 28.98 & 3.53 & 23 & 40 & 28.96 & 29.00 & 0.611 \\
\hline \multicolumn{8}{|c|}{$\underline{\text { Panel C: WWII-related data from replacement lists and war contracts }}$} \\
\hline Share drafted employees (1942-1945) & 0.23 & 0.03 & 0.13 & 0.33 & 0.23 & 0.23 & 0.180 \\
\hline Switched 3-digit SIC (1940-1945) & 1 & 0 & 1 & 1 & 1 & 1 & - \\
\hline Switched 2-digit SIC (1940-1945) & 0.57 & 0.50 & 0 & 1 & 0.57 & 0.57 & 0.556 \\
\hline Switched 1-digit SIC (1940-1945) & 0.37 & 0.48 & 0 & 1 & 0.37 & 0.38 & 0.257 \\
\hline Number of contracts (1940-1945) & 0.68 & 2.61 & 0 & 152 & 0.68 & 0.68 & 0.719 \\
\hline Value of contracts (1940-1945) & 25.11 & 293.01 & 0 & $27,145.94$ & 23.87 & 26.48 & 0.507 \\
\hline
\end{tabular}

Notes. Summary statistics for 11,575 firms that applied to the TWI program. Column 7 shows the p-value of the difference between columns 5 and 6. Panel A includes variables from the firm's financial statements in 1939. Plants is the total number of plants per firm; Employees is the number of employees per firm; Agriculture, Manufacturing, Transportation, and Services are indicators that equal one if a firm operates in agriculture, manufacturing, transportation, or services, respectively; Sales, Current assets, Total assets, Inventory, Injuries, Repairs, Bonus payments are expressed in 2020 million USD; TFP is the log of total factor productivity revenue, estimated using the method proposed by Gandhi, Navarro, and Rivers (2020); ROA is returns on assets, measured as profits over total assets. Panel B includes variables from the wartime replacement schedules in 1941. Share African-Americans is the share of African-American workers; Share women is the share of female workers; Year of education is the average years of formal education of the workforce; and Age of workforce is the average age of the workers. Panel C shows data on the firm exposure to WWII from either the replacement schedules and the war contracts. Share drafted employees is the share of employees drafted between 1942 and 1945; Switched $x$-digit SIC equals one if a firm's war products were in different x-digit 1939 SIC codes; Number of contracts is the yearly number of war contracts between 1940 and 1945; and Value of contracts is the yearly value of war contracts (in 2020 million USD). 
Table 2: Correlation between Firm and County Characteristics and Training Received

\begin{tabular}{|c|c|c|c|c|c|c|c|c|}
\hline & $\begin{array}{l}\text { TWI } \\
(1)\end{array}$ & $\begin{array}{l}\text { J-I } \\
(2)\end{array}$ & $\begin{array}{c}\mathrm{J}-\mathrm{R} \\
(3)\end{array}$ & $\begin{array}{c}\mathrm{J}-\mathrm{M} \\
(4)\end{array}$ & $\begin{array}{l}\mathrm{J}-\mathrm{I} \text { and } \mathrm{J}-\mathrm{R} \\
(5)\end{array}$ & $\begin{array}{l}\mathrm{J}-\mathrm{R} \text { and } \mathrm{J}-\mathrm{M} \\
\quad(6)\end{array}$ & $\begin{array}{l}\mathrm{J}-\mathrm{I} \text { and } \mathrm{J}-\mathrm{M} \\
(7)\end{array}$ & $\begin{array}{l}\text { All } \\
(8)\end{array}$ \\
\hline \multicolumn{9}{|c|}{ Panel A: Regressions of training variables on firm characteristics in period -1} \\
\hline $\begin{array}{l}p \text {-value of joint } \\
\text { significance }\end{array}$ & 0.32 & 0.76 & 0.69 & 0.55 & 0.92 & 0.14 & 0.76 & 0.65 \\
\hline Observations & 10,735 & 10,735 & 10,735 & 10,735 & 10,735 & 10,735 & 10,735 & 10,735 \\
\hline \multicolumn{9}{|c|}{$\underline{\text { Panel B: Regressions of training variables on firm characteristics, including number and value of government contracts, in period }-1}$} \\
\hline $\begin{array}{l}p \text {-value of joint } \\
\text { significance }\end{array}$ & 0.35 & 0.60 & 0.77 & 0.40 & 0.94 & 0.14 & 0.86 & 0.55 \\
\hline Observations & 10,727 & 10,727 & 10,727 & 10,727 & 10,727 & 10,727 & 10,727 & 10,727 \\
\hline \multicolumn{9}{|c|}{$\underline{\text { Panel C: Regressions of training variables on county characteristics in year } 1940}$} \\
\hline $\begin{array}{l}p \text {-value of joint } \\
\text { significance }\end{array}$ & 0.48 & 0.25 & 0.36 & 0.21 & 0.45 & 0.47 & 0.86 & 0.51 \\
\hline Observations & 10,745 & 10,745 & 10,745 & 10,745 & 10,745 & 10,745 & 10,745 & 10,745 \\
\hline \multicolumn{9}{|c|}{$\underline{\text { Panel D: Regressions of training variables on county characteristics in year } 1930}$} \\
\hline $\begin{array}{l}p \text {-value of joint } \\
\text { significance }\end{array}$ & 0.08 & 0.44 & 0.26 & 0.34 & 0.07 & 0.11 & 0.69 & 0.66 \\
\hline Observations & 10,859 & 10,859 & 10,859 & 10,859 & 10,859 & 10,859 & 10,859 & 10,859 \\
\hline \multicolumn{9}{|c|}{$\underline{\text { Panel E: Regressions of training variables on county characteristics in year } 1920}$} \\
\hline $\begin{array}{l}p \text {-value of joint } \\
\text { significance }\end{array}$ & 0.45 & 0.32 & 0.32 & 0.35 & 0.15 & 0.46 & 0.68 & 0.50 \\
\hline Observations & 10,873 & 10,873 & 10,873 & 10,873 & 10,873 & 10,873 & 10,873 & 10,873 \\
\hline
\end{tabular}

Notes. Panel A shows the $p$-value of the test of joint significance of the coefficients of fifteen firm characteristics observed in period -1 . The variables are: the logs of sales, value added, number of employees, number of plants, foundation year, the value of inventory, capital, current assets, investments, number of workers' strikes, monetary compensation for workers' injuries, performancebased bonus payments, number of subsidiaries, as well as distance to the nearest railroad station and distance to the nearest port. Panel B adds the inverse hyperbolic sine function of the number and value of government contracts. The regressions also include fixed effects for county-sector pairs, the application window, and the number of days between the opening of the window and the firm application. Panels C, D, and E show the $p$-value of the test of joint significance of the coefficients of several county characteristics measured in 1940, 1930, and 1920, respectively. The county-level variables are imputed to firms based on their location. These regressions include: log population, $\log$ of the manufacturing value added, log number of manufacturing establishments, log number of manufacturing employees, log average manufacturing wage, log total expenses in manufacturing, log value of manufacturing production, farms per capita, unemployment share (available only in 1930 and 1940), population per square mile, share of male residents, share of black population, share of urban population, share of illiterate population (available only in 1920 and 1930). County data are from IPUMS NHGIS, www.nhgis.org. The regressions also include fixed effects for subdistrict-sector pairs, the application window, and the number of days between the opening of the window and the firm application. Standard errors are clustered at the subdistrict-application window level. 
Table 3: Adoption of Managerial Practices

\begin{tabular}{|c|c|c|c|c|c|c|c|c|c|}
\hline & $\begin{array}{l}\text { Log } \\
\text { repairs } \\
(1) \\
\end{array}$ & $\begin{array}{c}\log \\
\text { maintenance } \\
(2) \\
\end{array}$ & $\begin{array}{c}\log \\
\text { injuries } \\
(3)\end{array}$ & $\begin{array}{c}\log \\
\text { bonus } \\
(4)\end{array}$ & $\begin{array}{c}\log \\
\text { strikes } \\
(5) \\
\end{array}$ & $\begin{array}{c}\text { Prob } \\
\text { training } \\
(6)\end{array}$ & $\begin{array}{c}\log \\
\text { inventory } \\
(7)\end{array}$ & $\begin{array}{c}\text { Log } \\
\text { product lines } \\
(8)\end{array}$ & $\begin{array}{c}\text { Prob } \\
\text { marketing } \\
(9)\end{array}$ \\
\hline J-I x Period 1 & $\begin{array}{c}-0.010^{* * *} \\
(0.000)\end{array}$ & $\begin{array}{c}0.005^{* * *} \\
(0.000)\end{array}$ & $\begin{array}{c}-0.020^{* *} \\
(0.010)\end{array}$ & $\begin{array}{l}-0.000 \\
(0.000)\end{array}$ & $\begin{array}{c}0.000 \\
(0.001)\end{array}$ & $\begin{array}{l}-0.001 \\
(0.001)\end{array}$ & $\begin{array}{l}-0.010 \\
(0.011)\end{array}$ & $\begin{array}{c}0.002 \\
(0.003)\end{array}$ & $\begin{array}{l}-0.001 \\
(0.001)\end{array}$ \\
\hline J-I x Period 5 & $\begin{array}{c}-0.033^{* * *} \\
(0.001)\end{array}$ & $\begin{array}{c}0.014^{* * *} \\
(0.001)\end{array}$ & $\begin{array}{c}-0.043^{* * *} \\
(0.010)\end{array}$ & $\begin{array}{l}-0.000 \\
(0.000)\end{array}$ & $\begin{array}{c}0.006^{* * *} \\
(0.002)\end{array}$ & $\begin{array}{c}-0.051^{* * *} \\
(0.006)\end{array}$ & $\begin{array}{c}0.007 \\
(0.010)\end{array}$ & $\begin{array}{l}-0.002 \\
(0.004)\end{array}$ & $\begin{array}{c}-0.028^{* * *} \\
(0.005)\end{array}$ \\
\hline J-I x Period 10 & $\begin{array}{c}-0.057^{* * *} \\
(0.001)\end{array}$ & $\begin{array}{c}0.025^{* * *} \\
(0.001)\end{array}$ & $\begin{array}{c}-0.064^{* * *} \\
(0.011)\end{array}$ & $\begin{array}{c}0.000 \\
(0.000)\end{array}$ & $\begin{array}{c}0.030^{* * *} \\
(0.004)\end{array}$ & $\begin{array}{c}-0.062^{* * *} \\
(0.006)\end{array}$ & $\begin{array}{c}0.008 \\
(0.012)\end{array}$ & $\begin{array}{l}-0.004 \\
(0.005)\end{array}$ & $\begin{array}{c}-0.064^{* * *} \\
(0.007)\end{array}$ \\
\hline J-R $x$ Period 1 & $\begin{array}{l}-0.000 \\
(0.000)\end{array}$ & $\begin{array}{c}0.000 \\
(0.000)\end{array}$ & $\begin{array}{c}0.004 \\
(0.010)\end{array}$ & $\begin{array}{c}0.414^{* * * *} \\
(0.000)\end{array}$ & $\begin{array}{l}-0.000 \\
(0.000)\end{array}$ & $\begin{array}{c}0.043^{* * *} \\
(0.010)\end{array}$ & $\begin{array}{l}-0.005 \\
(0.011)\end{array}$ & $\begin{array}{c}0.002 \\
(0.002)\end{array}$ & $\begin{array}{l}0.001^{*} \\
(0.001)\end{array}$ \\
\hline J-R x Period 5 & $\begin{array}{l}-0.000 \\
(0.000)\end{array}$ & $\begin{array}{c}0.000 \\
(0.000)\end{array}$ & $\begin{array}{c}0.011 \\
(0.010)\end{array}$ & $\begin{array}{c}0.431^{* * * *} \\
(0.000)\end{array}$ & $\begin{array}{c}-0.268 * * * \\
(0.006)\end{array}$ & $\begin{array}{c}0.628^{* * *} \\
(0.025)\end{array}$ & $\begin{array}{c}0.008 \\
(0.010)\end{array}$ & $\begin{array}{l}-0.001 \\
(0.004)\end{array}$ & $\begin{array}{c}-0.023^{* * *} \\
(0.004)\end{array}$ \\
\hline J-R x Period 10 & $\begin{array}{l}-0.000 \\
(0.000)\end{array}$ & $\begin{array}{l}-0.000 \\
(0.000)\end{array}$ & $\begin{array}{l}-0.000 \\
(0.009)\end{array}$ & $\begin{array}{c}0.459^{* * *} \\
(0.001)\end{array}$ & $\begin{array}{c}-0.268^{* * *} \\
(0.006)\end{array}$ & $\begin{array}{c}0.927^{* * *} \\
(0.008)\end{array}$ & $\begin{array}{c}0.033^{* * *} \\
(0.010)\end{array}$ & $\begin{array}{l}-0.000 \\
(0.005)\end{array}$ & $\begin{array}{c}-0.061^{* * *} \\
(0.006)\end{array}$ \\
\hline J-M x Period 1 & $\begin{array}{l}0.000 \\
(0.000)\end{array}$ & $\begin{array}{c}0.000 \\
(0.000)\end{array}$ & $\begin{array}{l}-0.001 \\
(0.010)\end{array}$ & $\begin{array}{c}0.000 \\
(0.000)\end{array}$ & $\begin{array}{c}0.000 \\
(0.000)\end{array}$ & $\begin{array}{c}0.001 \\
(0.001)\end{array}$ & $\begin{array}{c}-0.015^{* * *} \\
(0.005)\end{array}$ & $\begin{array}{c}0.015^{* * *} \\
(0.004)\end{array}$ & $\begin{array}{c}0.043^{* * *} \\
(0.010)\end{array}$ \\
\hline J-M x Period 5 & $\begin{array}{l}-0.000 \\
(0.000)\end{array}$ & $\begin{array}{c}0.000 \\
(0.000)\end{array}$ & $\begin{array}{c}0.001 \\
(0.009)\end{array}$ & $\begin{array}{l}-0.000 \\
(0.000)\end{array}$ & $\begin{array}{c}0.007^{* * *} \\
(0.002)\end{array}$ & $\begin{array}{c}-0.038^{* * *} \\
(0.005)\end{array}$ & $\begin{array}{c}-0.071^{* * *} \\
(0.006)\end{array}$ & $\begin{array}{c}0.538^{* * *} \\
(0.009)\end{array}$ & $\begin{array}{c}0.661^{* * *} \\
(0.024)\end{array}$ \\
\hline J-M x Period 10 & $\begin{array}{l}-0.000 \\
(0.000)\end{array}$ & $\begin{array}{c}0.000 \\
(0.000)\end{array}$ & $\begin{array}{c}0.006 \\
(0.009)\end{array}$ & $\begin{array}{l}-0.000 \\
(0.000)\end{array}$ & $\begin{array}{c}0.013^{* * *} \\
(0.002)\end{array}$ & $\begin{array}{c}-0.062^{* * *} \\
(0.006)\end{array}$ & $\begin{array}{c}-0.100^{* * *} \\
(0.007)\end{array}$ & $\begin{array}{c}0.606^{* * *} \\
(0.009)\end{array}$ & $\begin{array}{c}0.930^{* * *} \\
(0.008)\end{array}$ \\
\hline Observations & 67,472 & 67,472 & 67,472 & 67,472 & 67,472 & 67,472 & 67,472 & 67,472 & 67,472 \\
\hline $\mathrm{R}^{2}$ & 0.142 & 0.131 & 0.141 & 0.170 & 0.165 & 0.559 & 0.406 & 0.445 & 0.648 \\
\hline
\end{tabular}

Notes: This table shows the coefficients of the interactions between the training variables and three selected period dummies (out of 15 period dummies included). The omitted period is the year before the TWI training (period -1). The distance from the TWI intervention for the nontreated firms is imputed using the distance from the TWI intervention of the first participating firm in the same subdistrict and application window. All the dependent variables are logged with the exception of two dummy variables that measure whether firms reported expenditures for on-the-job training (column 6; mean=0.06) or for marketing activities (column 9; mean=0.05). The regressions also include the treatment variables in isolation, as well as fixed effects for county-sector-period combinations, the application window, and the number of days between the opening of the window and the firm application. The sample includes applicant firms that either received only one TWI training or no training at all. Standard errors are clustered at the level of subdistricts and application windows. ${ }^{* * *} \mathrm{p}<0.01,{ }^{* *} \mathrm{p}<0.05,{ }^{*} \mathrm{p}<0.1$. 
Table 4: Complementarity Effects on Managerial Practices

\begin{tabular}{|c|c|c|c|c|c|c|c|c|c|}
\hline & $\begin{array}{c}\log \\
\text { repairs } \\
(1)\end{array}$ & $\begin{array}{c}\log \\
\text { maintenance } \\
(2)\end{array}$ & $\begin{array}{c}\text { Log } \\
\text { injuries } \\
(3)\end{array}$ & $\begin{array}{c}\log \\
\text { bonus } \\
(4)\end{array}$ & $\begin{array}{c}\log \\
\text { strikes } \\
(5)\end{array}$ & $\begin{array}{c}\text { Prob } \\
\text { training } \\
(6)\end{array}$ & $\begin{array}{c}\log \\
\text { inventory } \\
(7)\end{array}$ & $\begin{array}{c}\text { Log } \\
\text { product lines } \\
(8)\end{array}$ & $\begin{array}{c}\text { Prob } \\
\text { marketing } \\
(9)\end{array}$ \\
\hline J-I x Post & $\begin{array}{c}-0.038^{* * *} \\
(0.003)\end{array}$ & $\begin{array}{c}0.014 * * * \\
(0.002)\end{array}$ & $\begin{array}{c}-0.037^{* * *} \\
(0.005)\end{array}$ & $\begin{array}{l}-0.002 \\
(0.003)\end{array}$ & $\begin{array}{c}0.009 * * * \\
(0.002)\end{array}$ & $\begin{array}{c}-0.035^{* * *} \\
(0.003)\end{array}$ & $\begin{array}{c}0.009^{* *} \\
(0.004)\end{array}$ & $\begin{array}{c}0.001 \\
(0.004)\end{array}$ & $\begin{array}{c}-0.026^{* * *} \\
(0.003)\end{array}$ \\
\hline J-R $\times$ Post & $\begin{array}{l}-0.001 \\
(0.003)\end{array}$ & $\begin{array}{l}-0.001 \\
(0.002)\end{array}$ & $\begin{array}{l}-0.004 \\
(0.005)\end{array}$ & $\begin{array}{c}0.390^{* * *} \\
(0.003)\end{array}$ & $\begin{array}{c}-0.194^{* * *} \\
(0.005)\end{array}$ & $\begin{array}{c}0.543^{* * *} \\
(0.008)\end{array}$ & $\begin{array}{c}0.011^{* * *} \\
(0.004)\end{array}$ & $\begin{array}{c}0.004 \\
(0.004)\end{array}$ & $\begin{array}{c}-0.027^{* * *} \\
(0.003)\end{array}$ \\
\hline J-M x Post & $\begin{array}{l}-0.004 \\
(0.003)\end{array}$ & $\begin{array}{l}-0.002 \\
(0.002)\end{array}$ & $\begin{array}{c}0.000 \\
(0.005)\end{array}$ & $\begin{array}{c}0.001 \\
(0.003)\end{array}$ & $\begin{array}{c}0.009 * * * \\
(0.002)\end{array}$ & $\begin{array}{c}-0.034^{* * *} \\
(0.003)\end{array}$ & $\begin{array}{c}-0.055^{* * *} \\
(0.006)\end{array}$ & $\begin{array}{c}0.334^{* * *} \\
(0.006)\end{array}$ & $\begin{array}{c}0.549^{* * *} \\
(0.008)\end{array}$ \\
\hline J-I not alone $\mathrm{x}$ Post & $\begin{array}{l}0.006^{*} \\
(0.003)\end{array}$ & $\begin{array}{c}-0.013^{* * *} \\
(0.002)\end{array}$ & $\begin{array}{c}0.007 \\
(0.005)\end{array}$ & $\begin{array}{c}0.002 \\
(0.004)\end{array}$ & $\begin{array}{c}0.107^{* * *} \\
(0.003)\end{array}$ & $\begin{array}{c}0.015^{* * *} \\
(0.004)\end{array}$ & $\begin{array}{c}-0.011^{* *} \\
(0.005)\end{array}$ & $\begin{array}{c}0.005 \\
(0.005)\end{array}$ & $\begin{array}{c}0.014^{* * *} \\
(0.004)\end{array}$ \\
\hline J-R not alone $\mathrm{x}$ Post & $\begin{array}{c}0.000 \\
(0.004)\end{array}$ & $\begin{array}{c}-0.007^{* * * *} \\
(0.002)\end{array}$ & $\begin{array}{c}0.004 \\
(0.005)\end{array}$ & $\begin{array}{c}-0.012^{* * * *} \\
(0.004)\end{array}$ & $\begin{array}{c}-0.101^{* * *} \\
(0.005)\end{array}$ & $\begin{array}{c}0.026^{* * * *} \\
(0.009)\end{array}$ & $\begin{array}{l}-0.006 \\
(0.005)\end{array}$ & $\begin{array}{l}-0.006 \\
(0.005)\end{array}$ & $\begin{array}{c}0.011^{* * *} \\
(0.004)\end{array}$ \\
\hline $\mathrm{J}-\mathrm{M}$ not alone $\mathrm{x}$ Post & $\begin{array}{c}0.004 \\
(0.003)\end{array}$ & $\begin{array}{c}0.006^{* * *} \\
(0.002)\end{array}$ & $\begin{array}{l}-0.004 \\
(0.005)\end{array}$ & $\begin{array}{l}-0.005^{*} \\
(0.003)\end{array}$ & $\begin{array}{c}0.107^{* * *} \\
(0.003)\end{array}$ & $\begin{array}{c}0.029^{* * * *} \\
(0.004)\end{array}$ & $\begin{array}{l}-0.007 \\
(0.006)\end{array}$ & $\begin{array}{c}0.066^{* * *} \\
(0.006)\end{array}$ & $\begin{array}{c}0.027^{* * *} \\
(0.009)\end{array}$ \\
\hline Observations & 134,288 & 134,288 & 134,288 & 134,288 & 134,288 & 134,288 & 134,288 & 134,288 & 134,288 \\
\hline $\mathrm{R}^{2}$ & 0.101 & 0.098 & 0.101 & 0.210 & 0.177 & 0.615 & 0.395 & 0.552 & 0.627 \\
\hline
\end{tabular}

Notes: This table shows the coefficients of the interactions between the training variables and a postTWI dummy. All the dependent variables are logged with the exception of two dummy variables that measure whether firms reported expenditures for on-the-job training (column 6; mean=0.18) or for marketing activities (column 9; mean=0.17). J-x is one for all firms that received the J-x training, while $\mathrm{J}$-x not alone is equal to one for firms that received the $\mathrm{J}$-x module with another type of TWI training. The regressions also include the training variables in isolation, as well as fixed effects for county-sector-period combinations, the application window, and the number of days between the opening of the window and the firm application. The sample includes all applicant firms. Standard errors are clustered at the level of subdistricts and application windows. ${ }^{* * *} \mathrm{p}<0.01,{ }^{*} \mathrm{p}<0.05, *$ $\mathrm{p}<0.1$. 
Table 5: Effects on Upstream and Downstream Firms

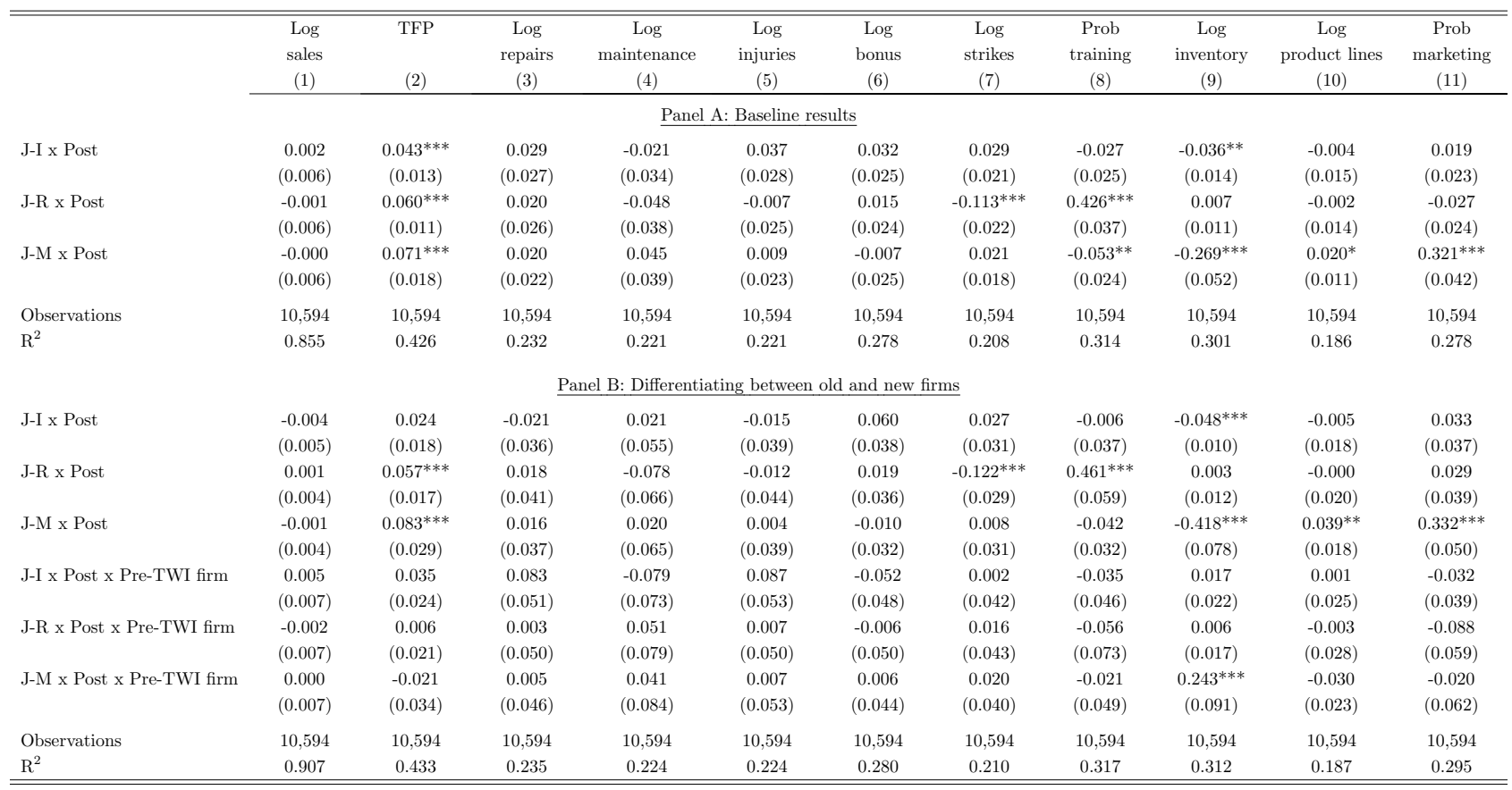

Notes. The sample used for this table includes 1,816 upstream and downstream firms linked to 1,572 firms that applied to the TWI program. Out of 1,816 upstream and downstream firms, 1,102 firms are in the supply chain of applicant firms that received at most one training. We use these 1,102 firms to obtain the results included in this table. The training variables are: J-I $=1$ for firms linked to applicants that received the Job-Instructions training; J-R $=1$ for firms linked to applicants that received the Job-Relations training; J-M $=1$ for firms linked to applicants that received the JobMethods training. The distance from the TWI intervention is imputed using the distance from the TWI program of the applicant firm with which the upstream/downstream firm has a contractual relationship. If an upstream/downstream firm joins the supply chain of an applicant firm after the latter received the TWI program, period 0 identifies the year of entry in the supply chain. Pre-TWI firm is equal to 1 for firms that were in the supply chain of applicants before the start of the TWI program. In panel A, the regressions also include the training variables by themselves, the Pre-TWI firm dummy by itself, a dummy for firms that are upstream with respect to the trained firm, as well as fixed effects for county-sector-period combinations, the application window of the applicant firm, and the number of days between the opening of the window and the firm application. Panel B shows the results of triple-difference specifications. These regressions also include the interaction between the training variable and the Pre-TWI firm dummy, the interaction between the period fixed effects and the Pre-TWI firm dummy, the training variables by themselves, the Pre-TWI firm dummy by itself, a dummy for firms that are upstream with respect to the trained firm, as well as fixed effects for county-sector-period combinations, the application window of the applicant firm, and the number of days between the opening of the window and the firm application. Standard errors are clustered at the level of subdistricts and application windows. ${ }^{* * *} \mathrm{p}<0.01,{ }^{* *} \mathrm{p}<0.05,{ }^{*} \mathrm{p}<0.1$. 


\section{Online Appendix}

\section{A Additional Figures and Tables}

Figure A1: Instruction Cards for Each J-Module

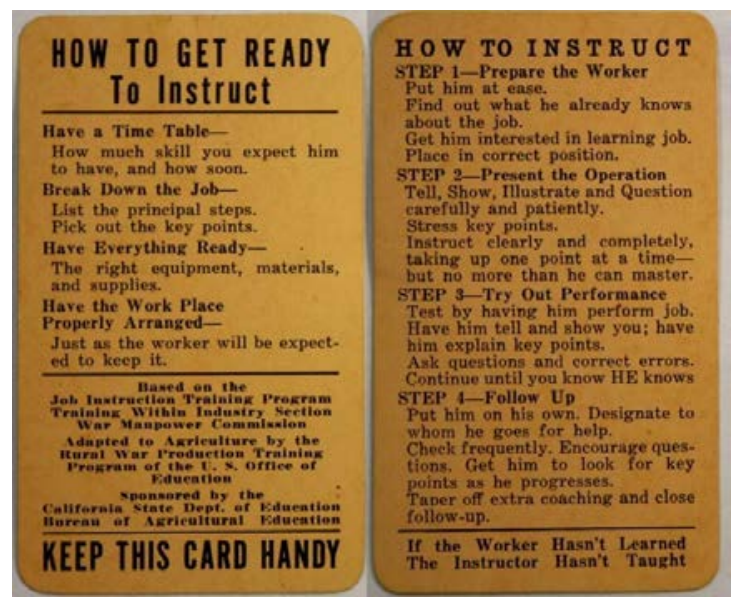

Panel A: Job Instruction

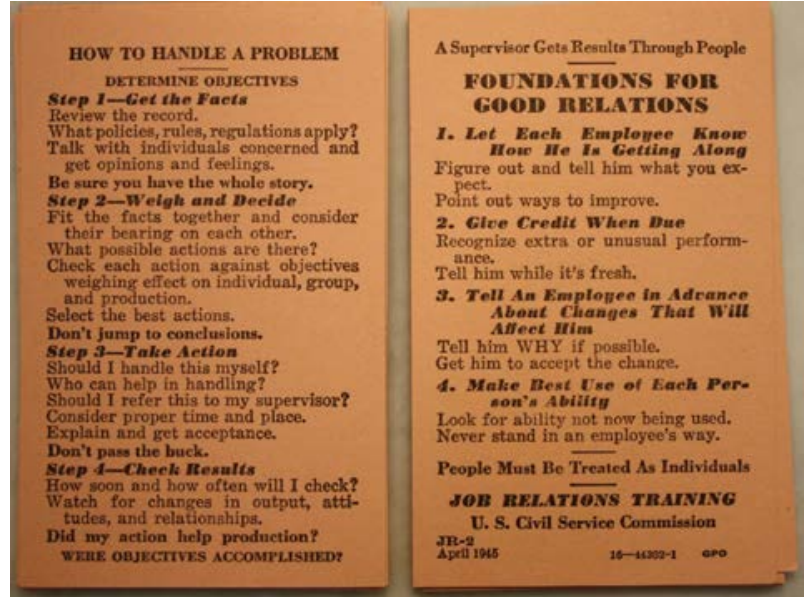

Panel B: Job Relations

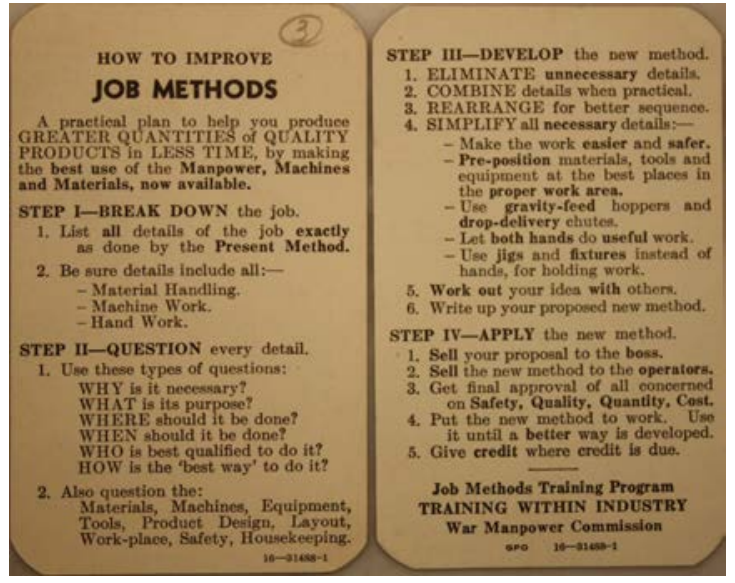

Panel C: Job Methods

Notes. The TWI training was designed to be simple and immediately usable. To emphasize these features, the TWI administration prepared instruction cards for each J-Module that trained supervisors could keep in their pockets while they were working. These instruction cards reported the main 4 steps (and their sub-steps) that characterized each module. It is important to note that these 4 "theoretical" steps did not constitute the entirety of the TWI trainings. A large portion of the class time was dedicated to in-class student presentations on how to apply TWI concepts in their firms. 
Figure A2: Pre-TWI Trends

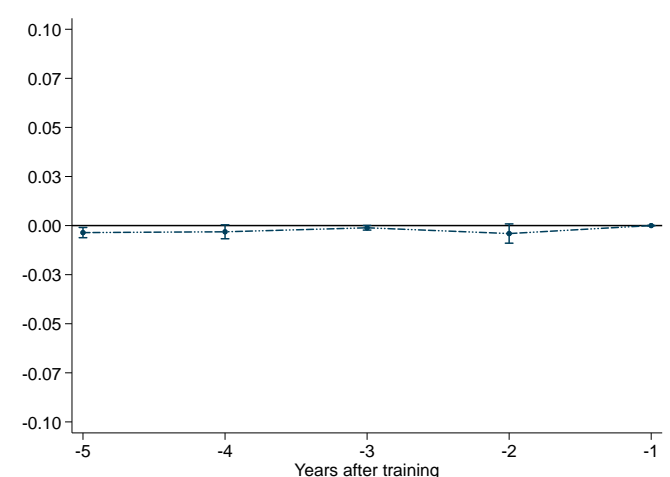

Panel A: Sales, TWI

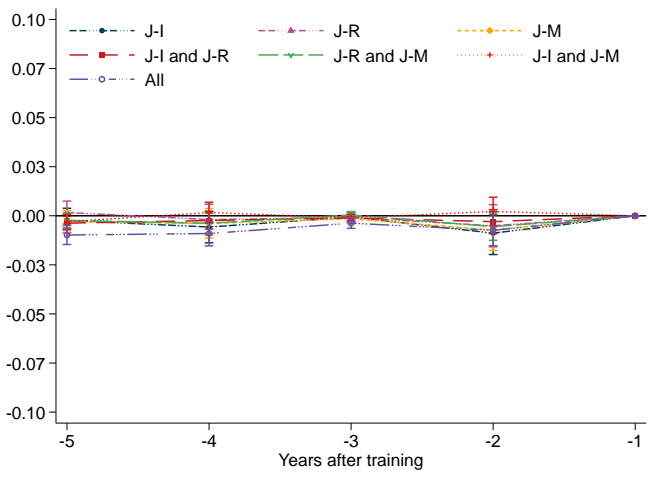

Panel D: Sales, all trainings

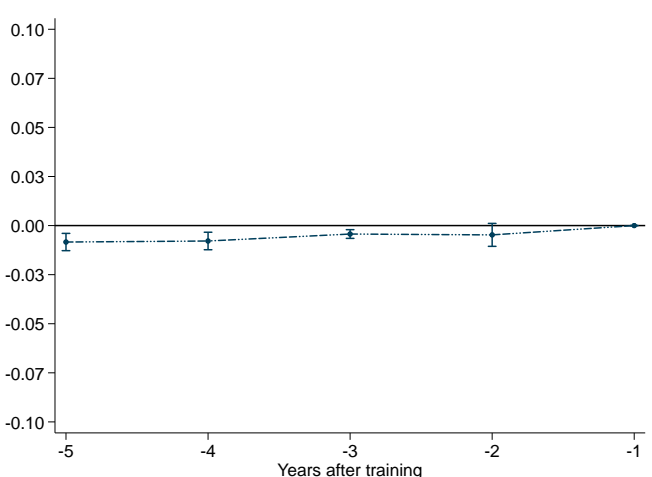

Panel B: TFP, TWI

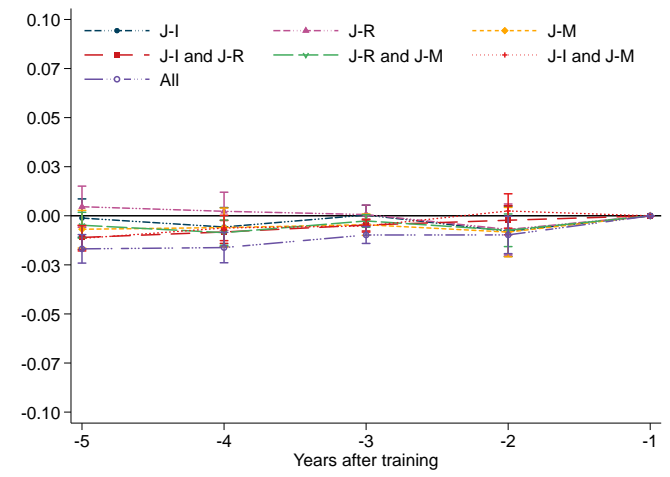

Panel E: TFP, all trainings

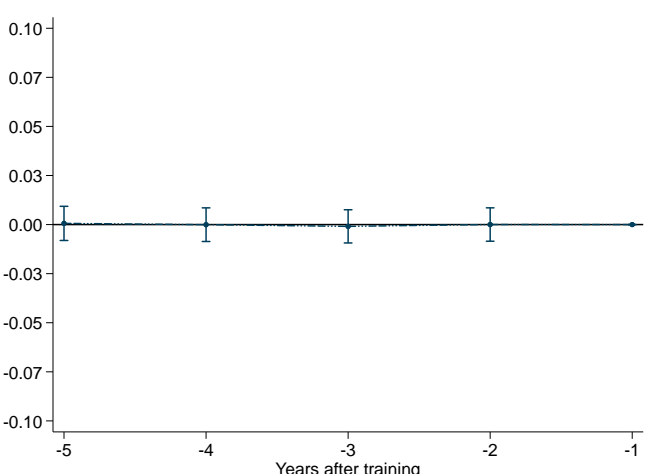

Panel C: ROA, TWI

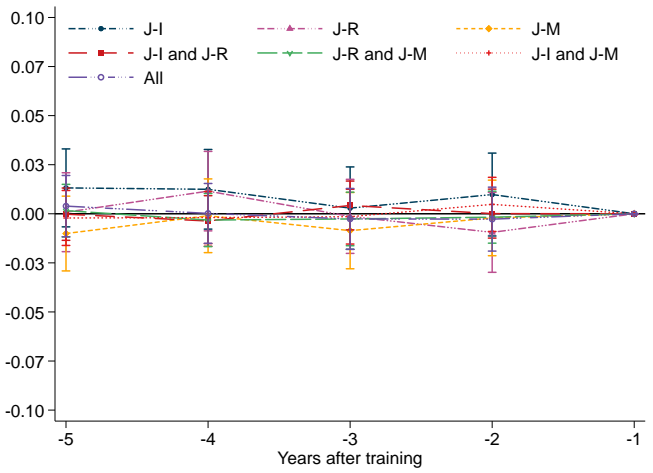

Panel F: ROA, all trainings

Notes. Coefficients of the interactions between pre-TWI period dummies and either a single TWI dummy variable (Panels A, B, and C) or dummies with different combinations of training (Panels, D, E, and F). The omitted period is -1 , one year before the TWI training. The distance from the TWI intervention for the nontrained firms is imputed using the distance from the TWI intervention of the first participating firm in the same subdistrict and application window. The dependent variables are: logged annual sales (Panels A and D), TFP computed with the Gandhi, Navarro, and Rivers (2020) method (Panels B and E), logged return on assets (ROA), computed as the ratio between profits and fixed gross assets (Panels C and F). The sample used for these graphs includes all 11,575 firms that applied to the TWI program. The vertical bars denote 95 percent confidence intervals. The standard errors are clustered at the level of subdistricts and application windows. 
Figure A3: Influence of Higher Attrition Among Nontrained Applicants

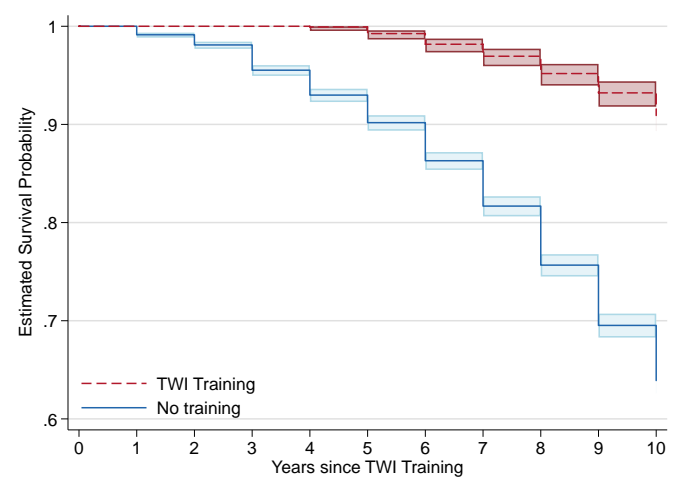

Panel A: Kaplan-Meier Survival Curve

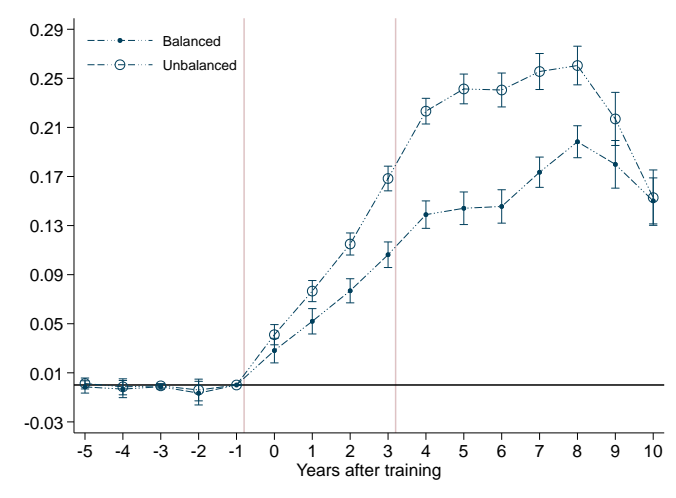

Panel B: Sales, Unbalanced sample

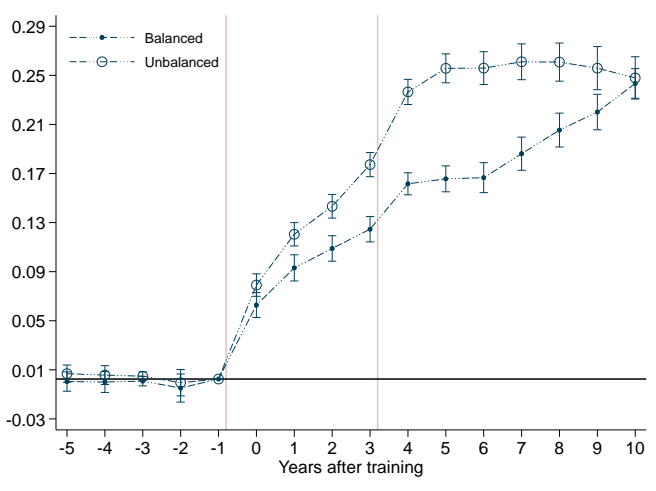

Panel C: TFP, Unbalanced sample
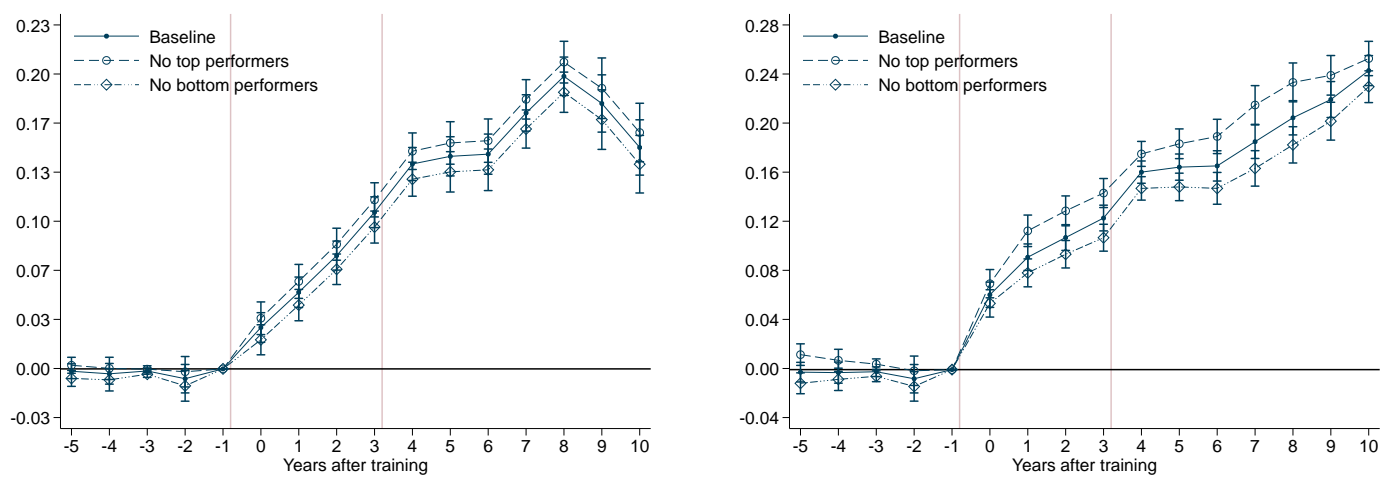

Panel D: Sales, Treatment-effect bounds

Panel E: TFP, Treatment-effect bounds

Notes. Panel A shows the Kaplan-Meier survival curves for applicants that received one training and for applicants that did not receive any training. Panels B and C show the treatment effects on log sales (Panel B) and log TFP (Panel C) using an unbalanced sample, allowing for firm exit and entry. Panels D and E bound the treatment effects by estimating extreme cases of attrition. Specifically, the regressions on exit indicate that trained applicants were 25-percentage-points less likely to exit the sample, compared with nontrained applicants. In Panels D and E, we assume that this difference in attrition affected either all the top performers or all the bottom performers among the trained applicants. In "No top performers," we remove all trained applicants in the top quartile of the distribution of sales (Panel D) or TFP (Panel E) in period -1. In "No bottom performers," we remove all trained applicants in the bottom quartile of the distribution of sales (Panel D) or TFP (Panel E) in period -1. 
Figure A4: Comparison with Effect Sizes in the Literature

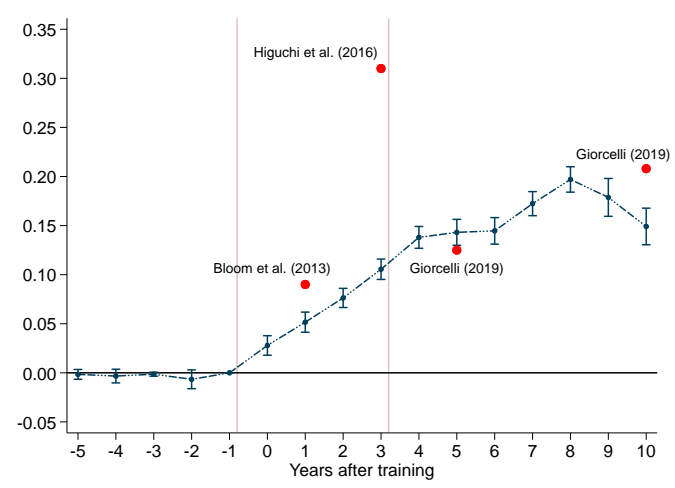

Panel A: Sales

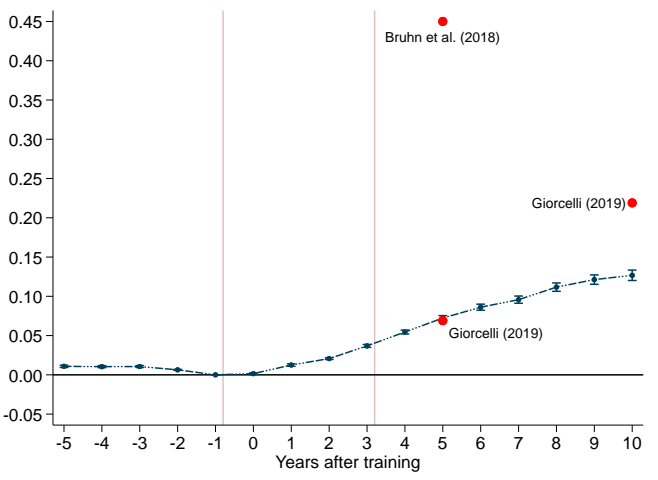

Panel C: Employees

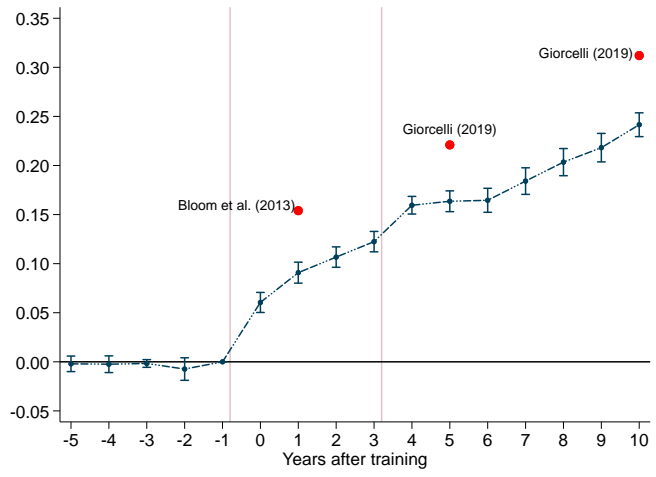

Panel B: TFP

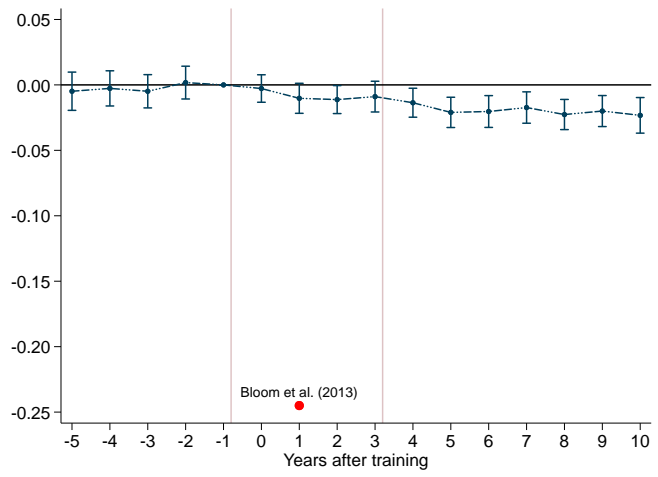

Panel D: Inventory

Notes. Bloom et al. (2013a) shows results on output, instead of sales. All variables are logged. 
Figure A5: Robustness Checks of Main Results on Sales and TFP

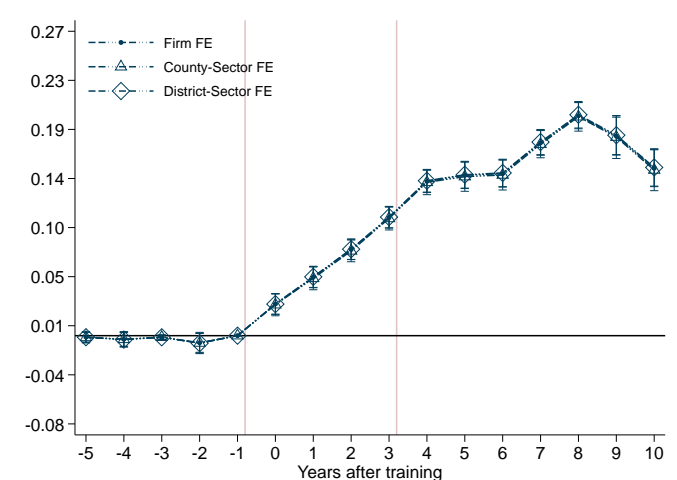

Panel A: Sales, Alternative fixed effects

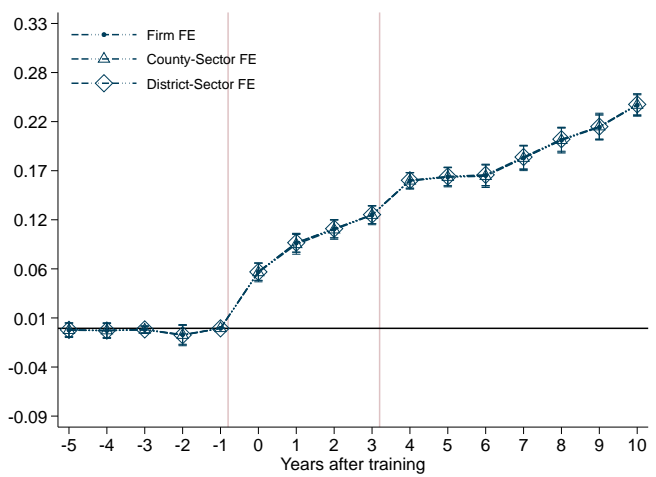

Panel D: TFP, Alternative fixed effects

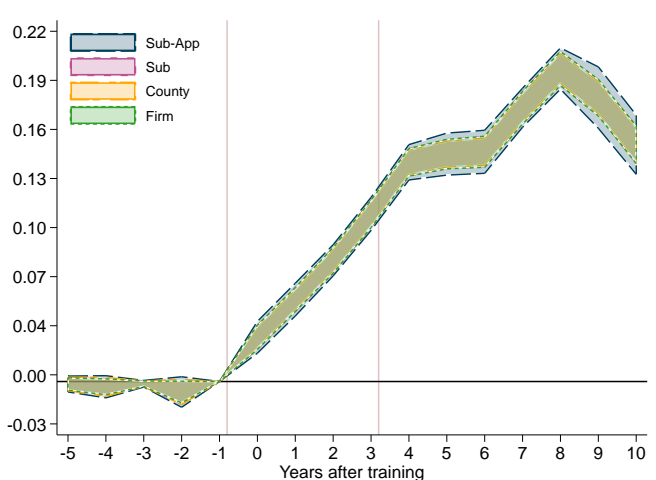

Panel B: Sales, Alternative clustering

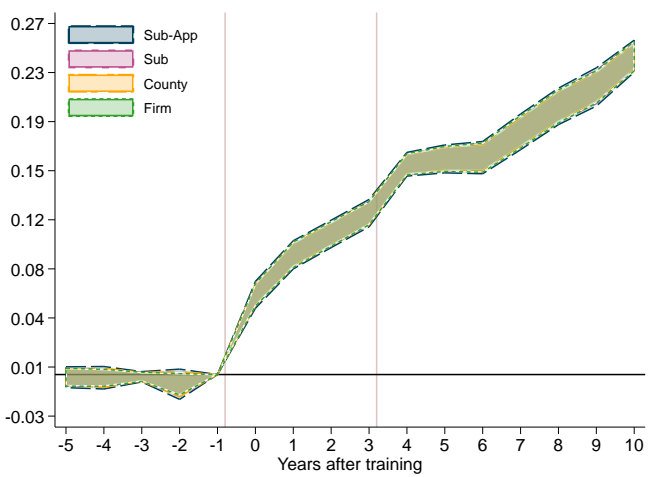

Panel E: TFP, Alternative clustering

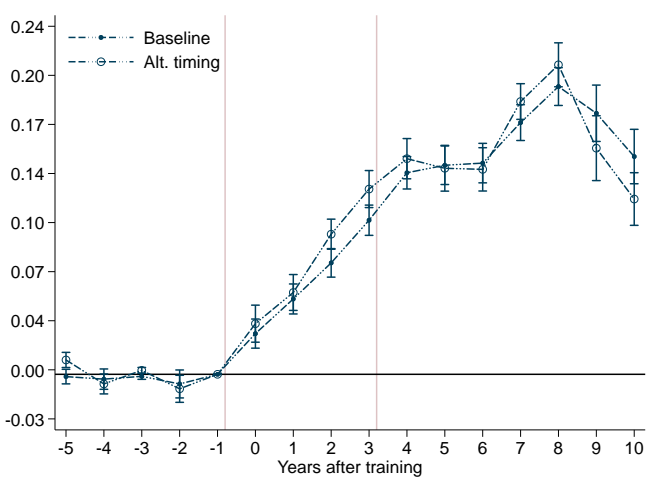

Panel C: Sales, Alternative timing

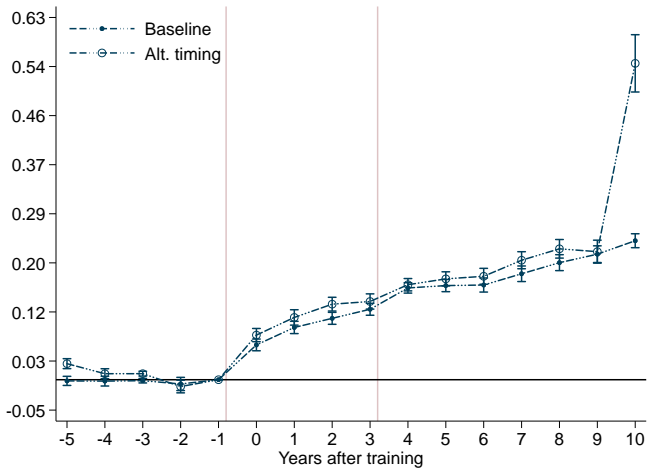

Panel F: TFP, Alternative timing

Notes. The dependent variable is the log of yearly sales revenues in panels A to C and TFP, estimated using the Gandhi, Navarro, and Rivers (2020) method, in panels D to F. Panels A and D show treatment effects including firm fixed effects or district-sector-time fixed effects, instead of county-sector-time fixed effects. Panels B and E show the effect of clustering the standard errors at the subdistrict, county, or firm level, instead of at the level of subdistricts and application windows. In panels $\mathrm{C}$ and $\mathrm{F}$, the distance from the TWI intervention for the nontrained firms is imputed using the distance from the TWI intervention of the last, instead of the first, trained firm in the same subdistrict and application window. 
Figure A6: Effects of Different J-Modules on Firm Performance

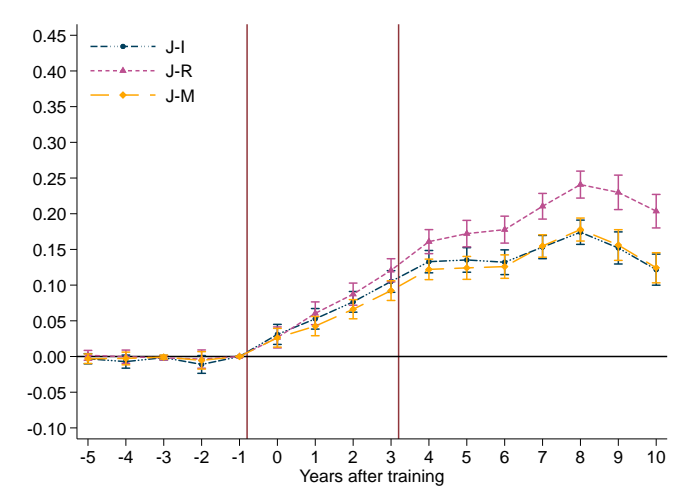

Panel A: Sales, DID

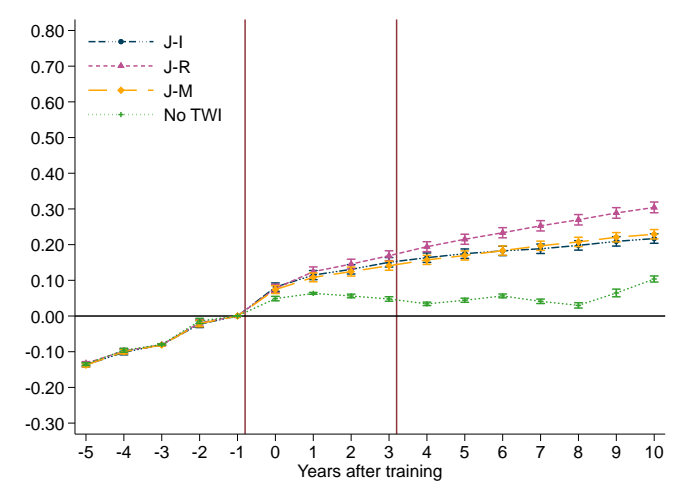

Panel D: Sales, Single Difference

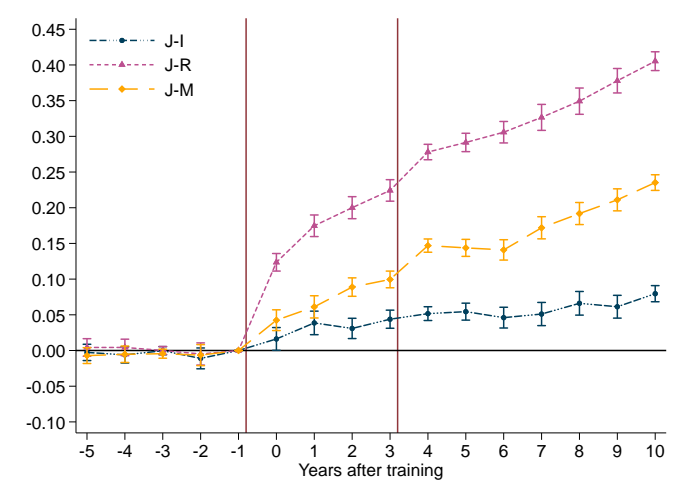

Panel B: TFP, DID

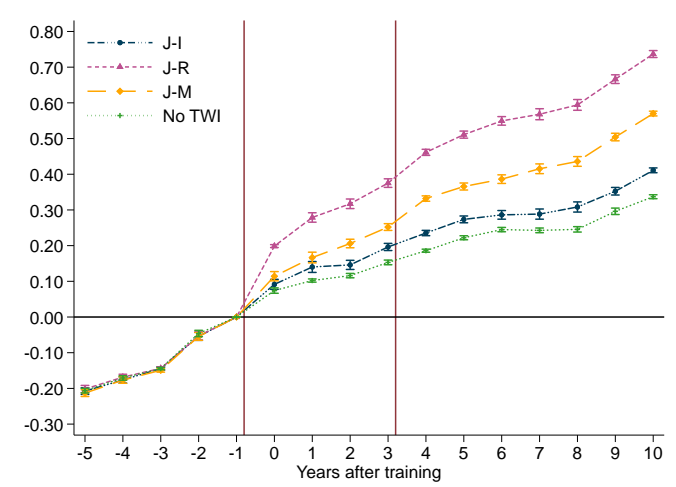

Panel E: TFP, Single Difference

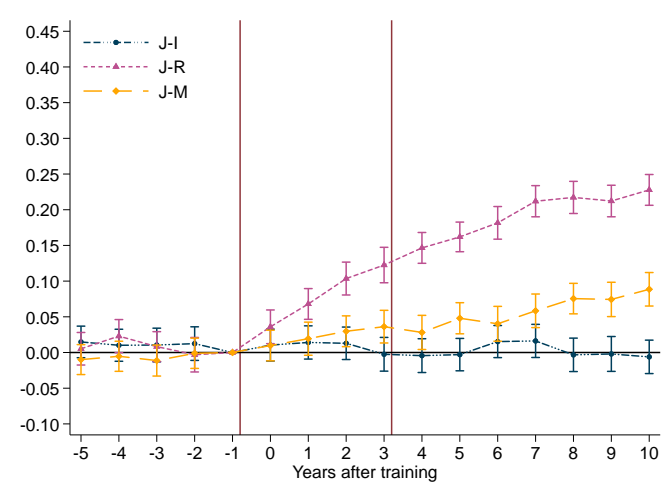

Panel C: Log ROA, DID

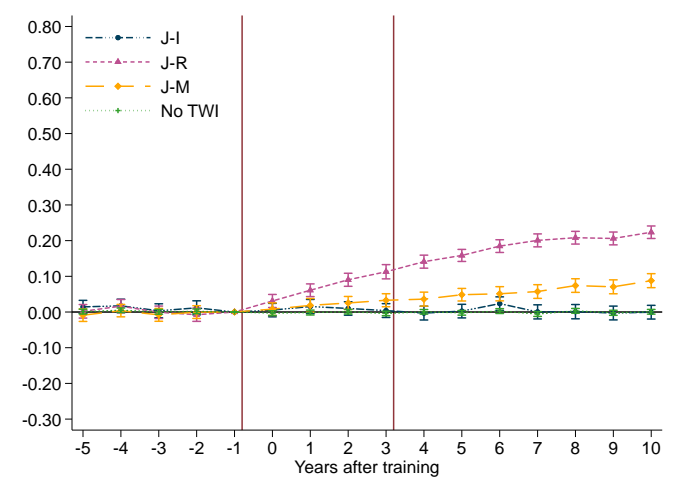

Panel F: Log ROA, Single Difference

Notes. Panels A-C show difference-in-differences coefficients, while panels D-F show single-difference coefficients. These regressions also include fixed effects for county-sector-period combinations, the application window, and the number of days between the opening of the window and the firm application. The distance from the TWI intervention for the nontreated firms is imputed using the distance from the TWI intervention of the first participating firm in the same subdistrict and application window. The dependent variables are log sales (Panels A and D), TFP computed with the Gandhi, Navarro, and Rivers (2020) method (Panels B and D), log of return on assets (Panels $\mathrm{C}$ and $\mathrm{F}$ ). The sample includes applicant firms that either received only one TWI training or no training at all. The vertical bars denote 95 percent confidence intervals. The first vertical red line identifies the beginning of the TWI program. The second vertical red line identifies the end of World War II for most applicant firms. The standard errors are clustered at the level of subdistricts and application windows. 
Figure A7: Horizontal Spillovers

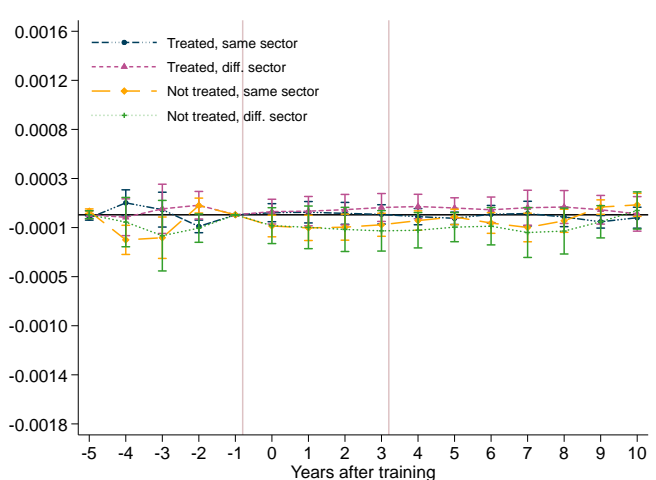

Panel A: Sales, \# nearby applicants

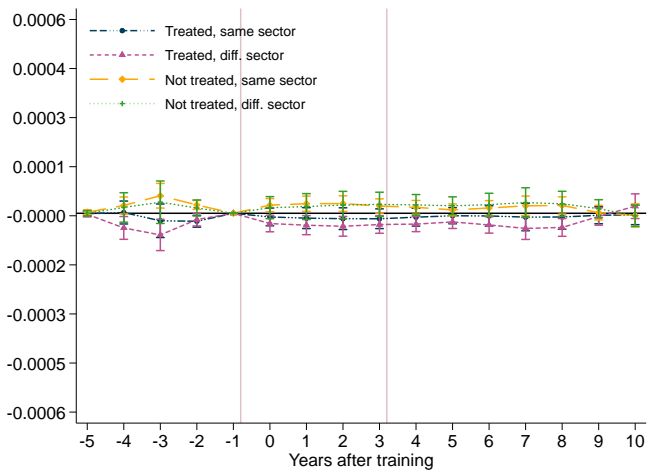

Panel D: Sales, distance to applicants

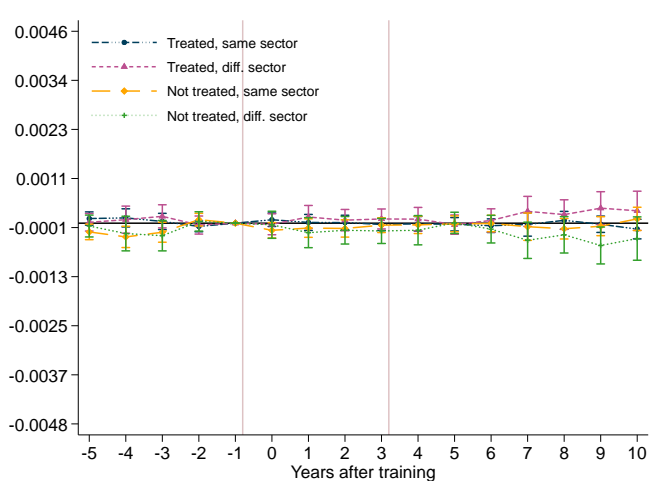

Panel B: TFP, \# nearby applicants

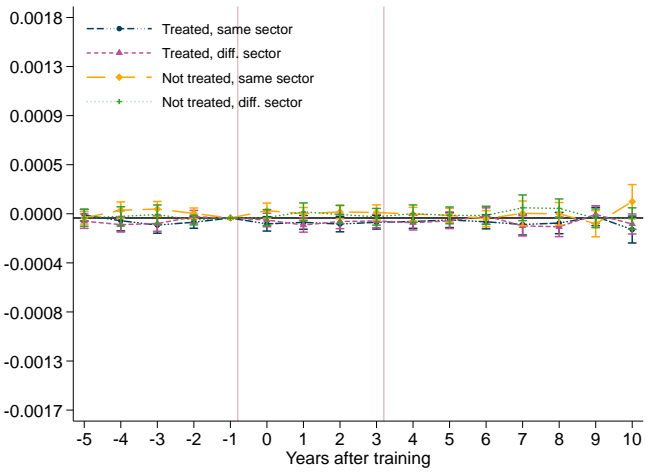

Panel E: TFP, distance to applicants

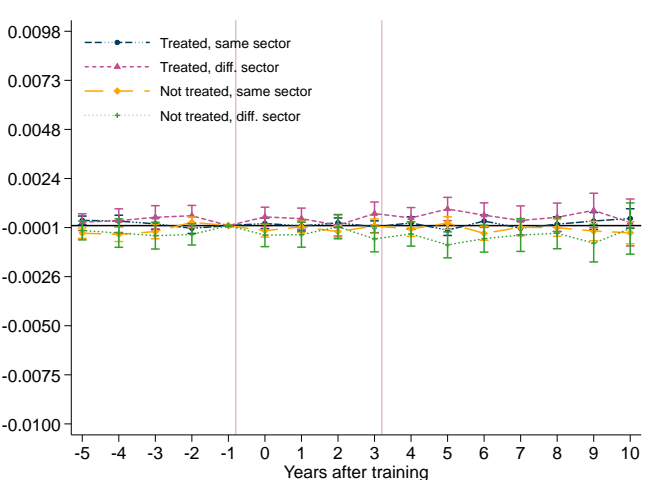

Panel C: ROA, \# nearby applicants

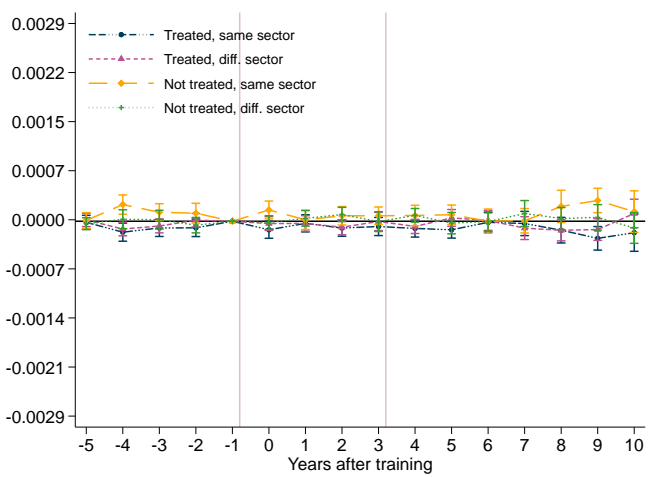

Panel F: ROA, distance to applicants

Notes. The sample used for these graphs includes 11,536 war contractors that did not apply to the TWI program and for which we found financial statements (out of 13,818 total nonapplicants). In panels A-C, the coefficients shown are the interactions between the log number of applicants in the area and period dummies. The number of applicants is divided between trained and nontrained firms and between firms in the same or different sector (agriculture, manufacturing, transportation, or services). Panels D-F use the log of the average distance from applicant firms, instead of the log number of firms. In order to compute the number of nearby applicant firms and their average distance to nonapplicant firms, we divided the 364 subdistricts into 52 groups of 7 adjacent subdistricts. Period 0 coincides with the modal treatment year within each of the 52 groups of subdistricts. All regressions also include firm fixed effects. The standard errors are clustered at the subdistrict level. 
Figure A8: Effects of TWI Training on Matched Sample

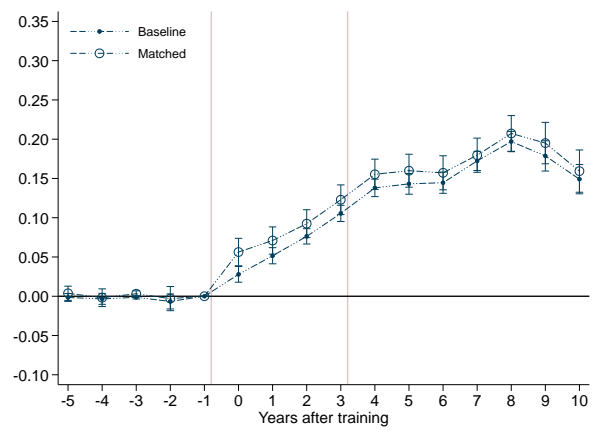

Panel A: Sales

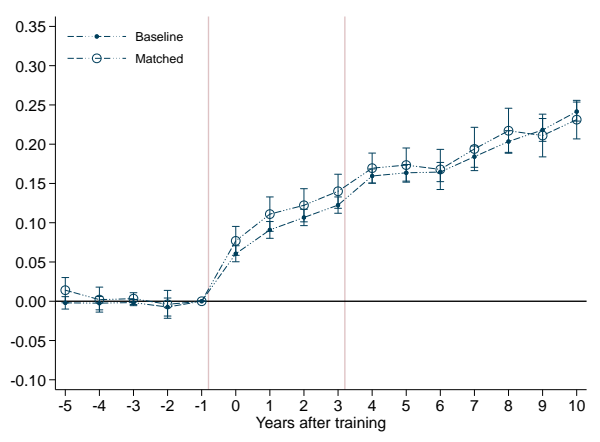

Panel B: TFP

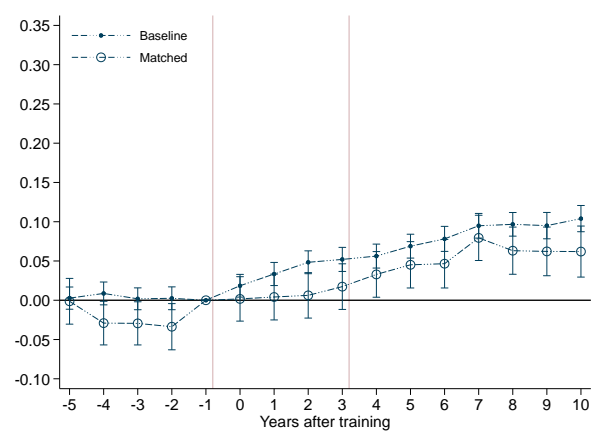

Panel C: ROA

Notes. These graphs replicate the estimation shown in Figure 3 on a smaller sample of applicant firms matched to nonapplicants based on their characteristics in 1939. The matching was based on propensity scores, using a nearest-neighbor algorithm without replacement. The variables used for the matching were the number of plants and employees in 1939, TFP in 1939, distance from the nearest port and railroad station, sector, and fixed effects for the 22 TWI districts. The standard errors are clustered at the level of subdistricts and application windows.

Figure A9: Change in Status Quo, Switching to War Production

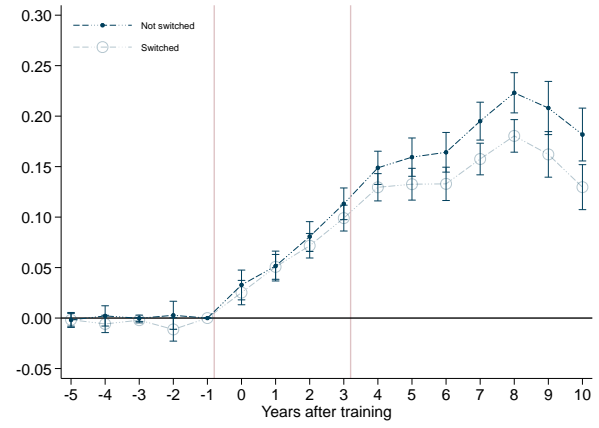

Panel A: Sales

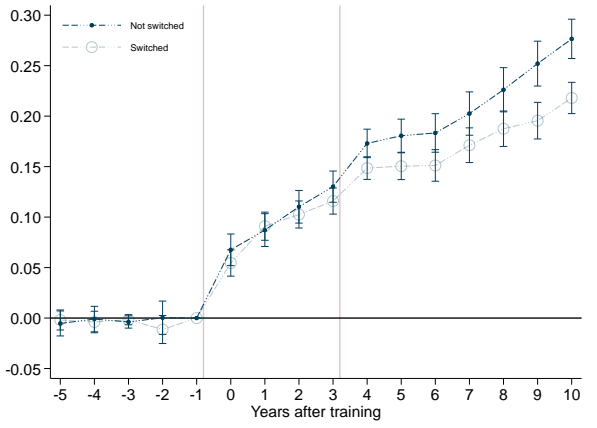

Panel B: TFP

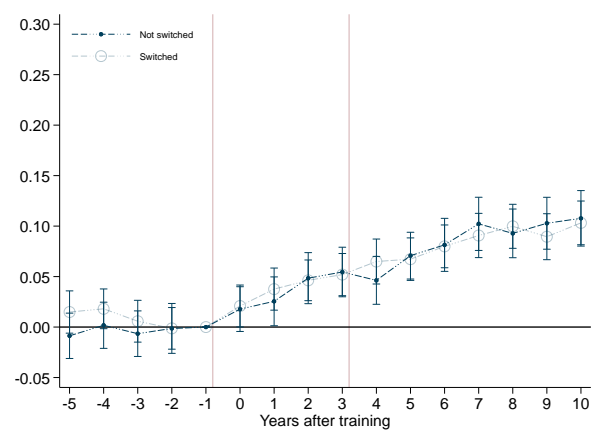

Panel C: ROA

Notes. These graphs show the interactions between the training variables and the period dummies distinguishing between firms that did or did not switch production during World War II. Specifically, Switched 2-digit SIC equals one if a firm's war products were in different 2-digit 1939 SIC codes. The standard errors are clustered at the level of subdistricts and application windows. 
Figure A10: Loss of Human Capital

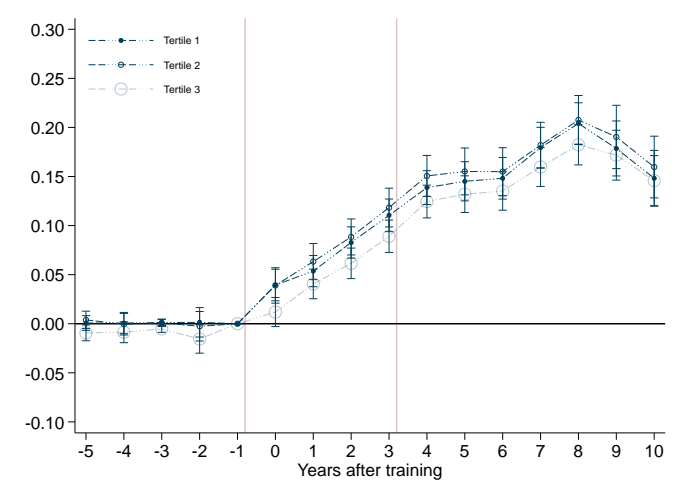

Panel A: Sales, share of drafted workers

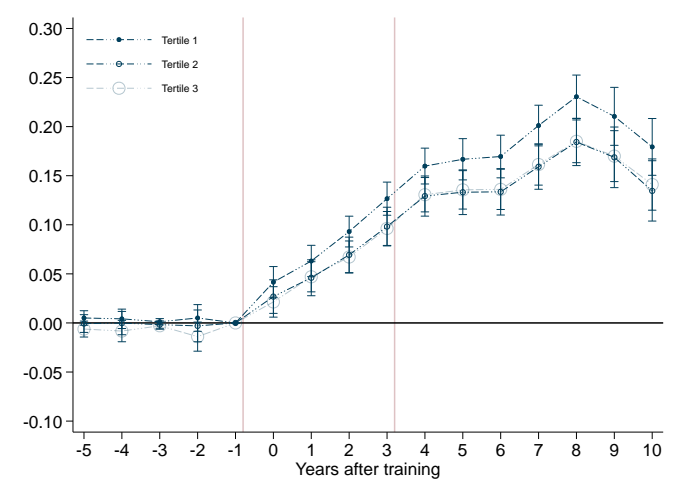

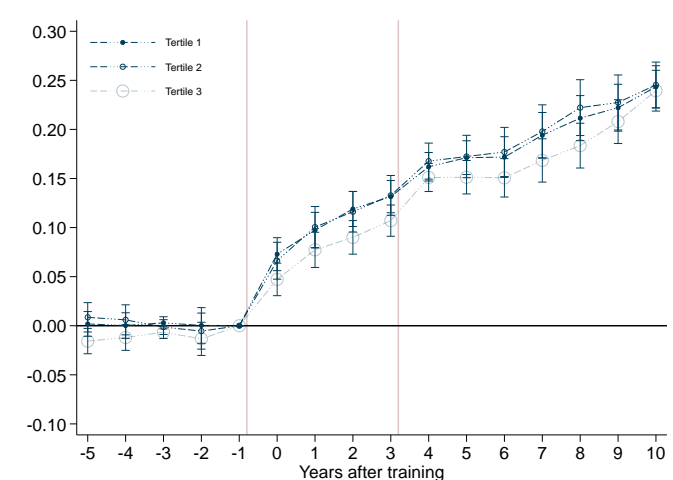

Panel B: TFP, share of drafted workers

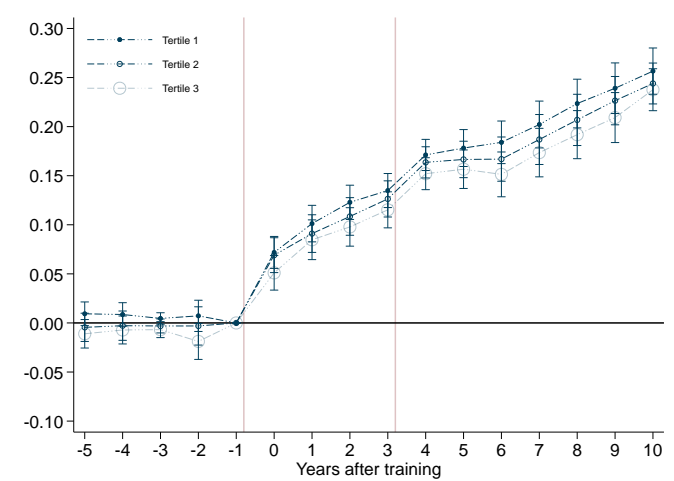

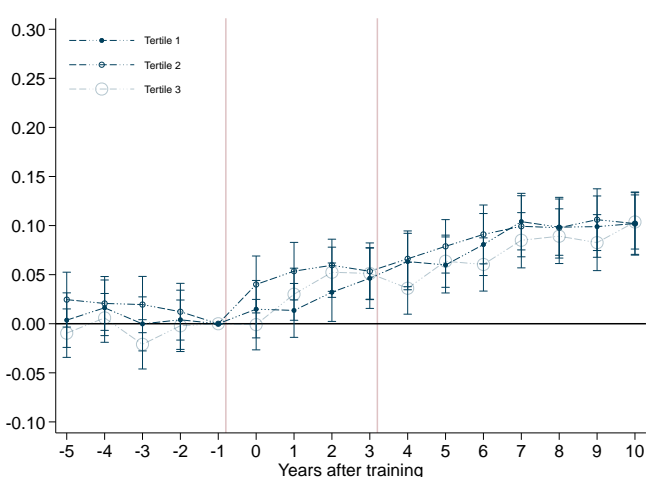

Panel C: ROA, share of drafted workers

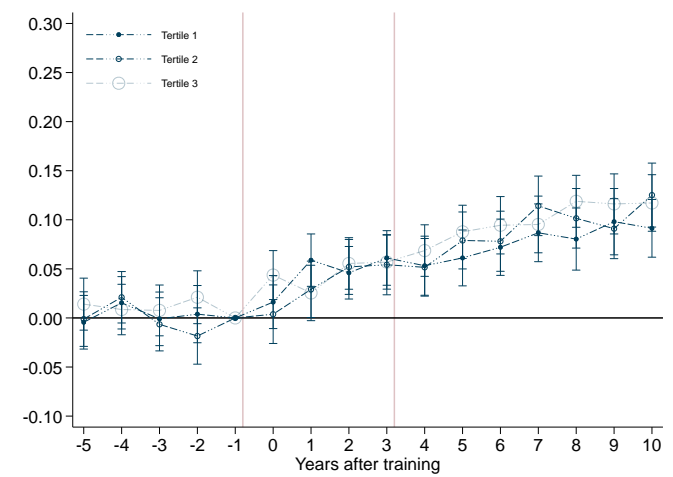

Panel D: Sales, share of managers leaving

Panel E: TFP, share of managers leaving

Panel F: ROA, share of managers leaving

Notes. Panels A to C show the treatment effects estimated separately by tertiles of the share of employees drafted during World War II. Panels D to F show the treatment effects estimated separately by tertiles of the share of top managers leaving the firm by 1955 . To compute this variable, we compare the list of top executives in 1955 (or last year in which a firm is observed) to the list of top executives in period 0 , the year of the TWI training. All regressions include the training variable in isolation, as well as fixed effects for county-sector-period combinations, the application window, and the number of days between the opening of the window and the firm application. The standard errors are clustered at the level of subdistricts and application windows. 
Figure A11: Effects of TWI Training on War Contracts

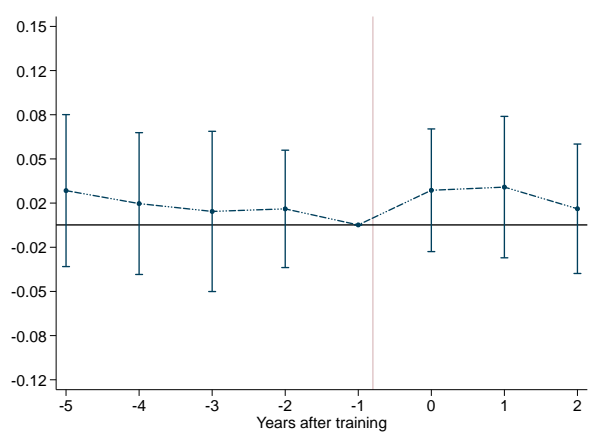

Panel A: Has contracts

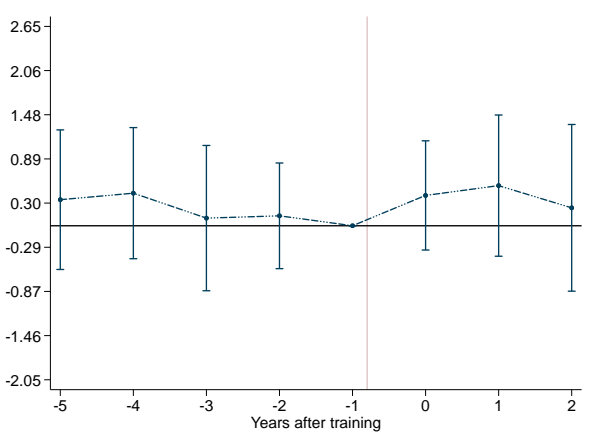

Panel B: Value contracts

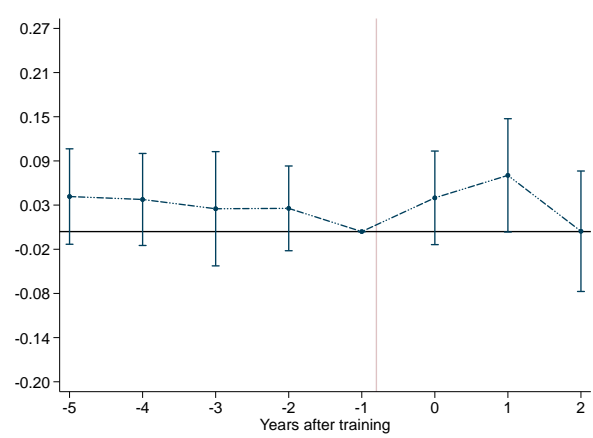

Panel C: Number contracts

Notes. These graphs show the effects of TWI training on variables that describe the relationship between applicant firms and the federal government. Has contracts is a dummy equal to one for firms with at least one new contract in a given year. Number contracts and Value contracts are the inverse hyperbolic sine function (due to many zeros) of the number and value of war contracts granted to each firm per year. These variables come from war contracts data and are therefore available only between 1940 and 1945. The number of firms with nonmissing values are 3,974 in period $-5,7,332$ in period $-4,10,607$ in period $-3,11,545$ in period $-2,11,567$ in period $-1,11,575$ in period 0, 7,601 in period 1, and 4,243 in period 2. All regressions also include fixed effects for county-sector-period combinations, the application window, and the number of days between the opening of the window and the firm application. Standard errors are clustered at the level of subdistricts and application windows. 
Figure A12: Other Heterogeneous Effects

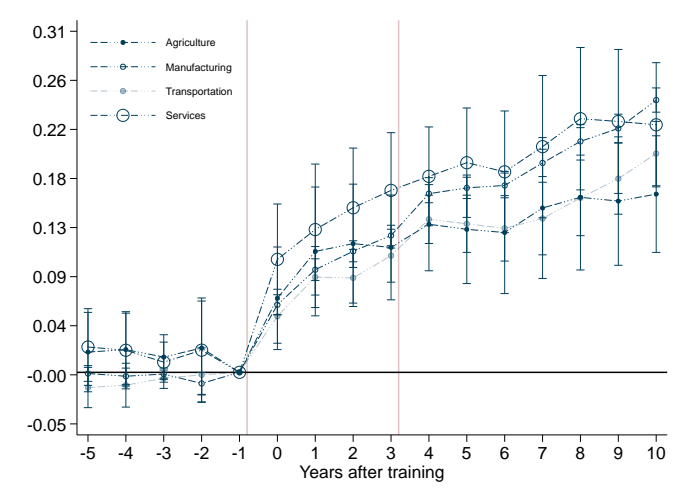

Panel A: Sectors

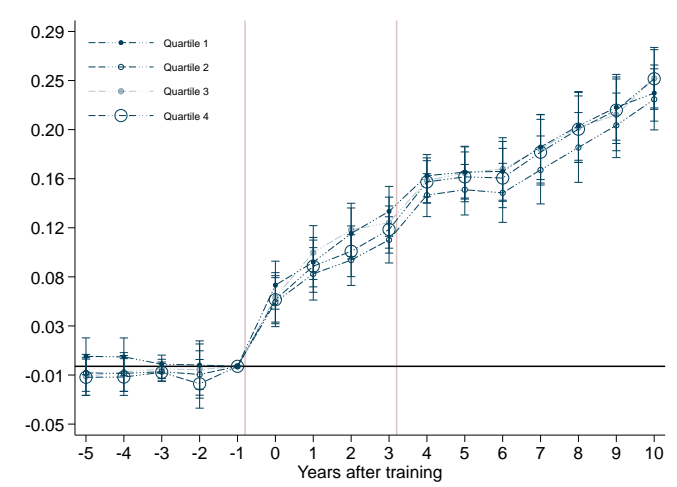

Panel D: Firm size

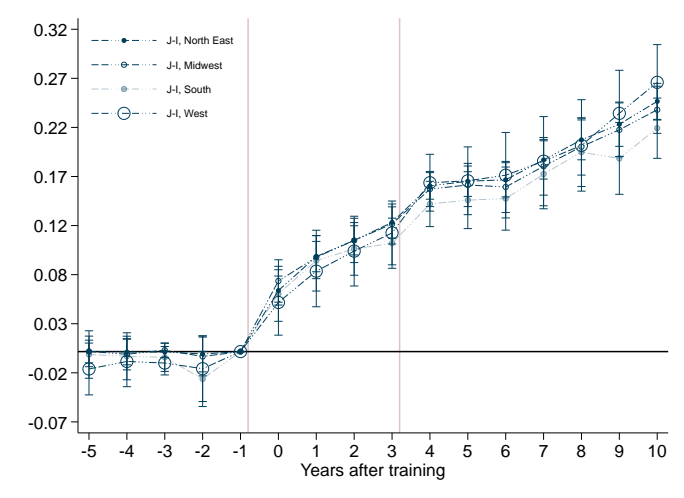

Panel B: Regions

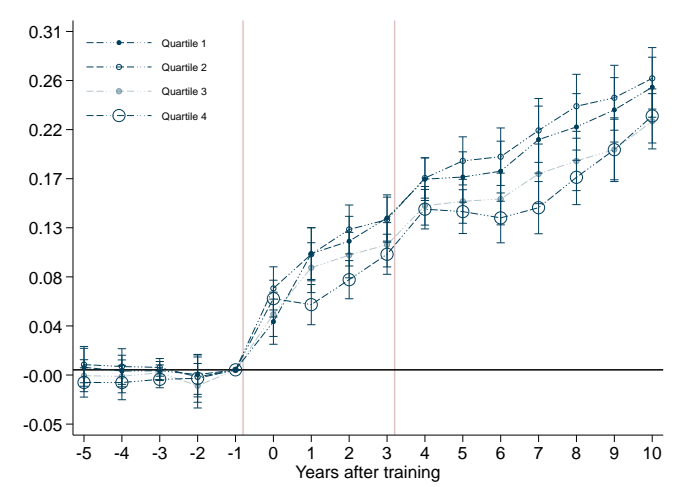

Panel E: Initial TFP level

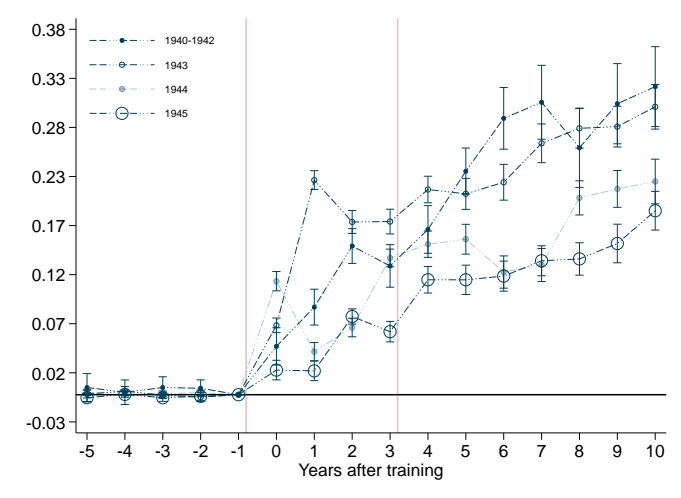

Panel C: Treatment years

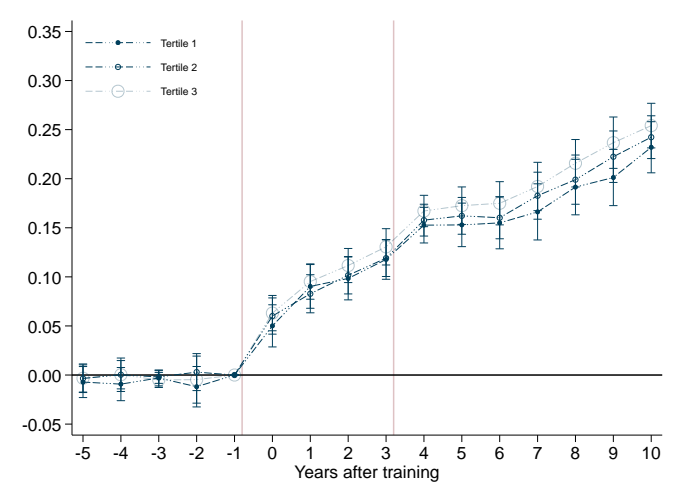

Panel F: Instructors from private sector

Notes. In all panels, the dependent variable is the log of TFP, estimated using the Gandhi, Navarro, and Rivers (2020) method. Panel A shows the treatment effects estimated separately by sector. Panel B shows the treatment effects estimated separately by U.S. Census Bureau regions. Panel $\mathrm{C}$ shows the treatment effects estimated separately by training year. Panel D shows the treatment effects estimated separately by quartiles of workforce size in period -1 . Panel E shows the treatment effects by quartiles of TFP in period -1 . Panel F shows the treatment effects by tertiles of the distribution of TWI instructors from the private sector. All regressions also include fixed effects for county-sector-period combinations, the application window, and the number of days between the opening of the window and the firm application. The standard errors are clustered at the level of subdistricts and application windows. 
Table A1: List of 22 TWI Districts

\begin{tabular}{|c|c|c|}
\hline District Name & States & Main Office Location \\
\hline 1) Upper New England & $\begin{array}{l}\text { Maine; Massachusetts; Vermont; New } \\
\text { Hampshire }\end{array}$ & Boston \\
\hline 2) Lower New England & Connecticut; Rhode Island & New Haven \\
\hline 3) Upstate New York & $\begin{array}{l}\text { New York state (excluding Metropolitan } \\
\text { New York) }\end{array}$ & New York \\
\hline 4) Metropolitan New York & Metropolitan New York & New York \\
\hline 5) New Jersey & New Jersey & Newark \\
\hline 6) Eastern Pennsylvania; Delaware & Eastern Pennsylvania; Delaware & Philadelphia \\
\hline 7) Maryland & Maryland & Baltimore \\
\hline 8) Atlantic Central & Virginia; North Carolina; South Carolina & Raleigh \\
\hline 9) South-Eastern States & $\begin{array}{l}\text { Georgia; Florida; Alabama; Mississippi; } \\
\text { Central and Eastern Tennessee }\end{array}$ & Atlanta \\
\hline 10) Ohio Valley & $\begin{array}{l}\text { Southern Ohio; Southern West Virginia, } \\
\text { Kentucky }\end{array}$ & Cincinnati \\
\hline 11) Western Pennsylvania & $\begin{array}{l}\text { Western Pennsylvania (except Erie } \\
\text { County); Northern West Virginia }\end{array}$ & Pittsburgh \\
\hline 12) Northern Ohio & $\begin{array}{l}\text { Northern Ohio (expect Lucas County); } \\
\text { Erie County (PA) }\end{array}$ & Cleveland \\
\hline 13) Michigan & Michigan; Lucas County $(\mathrm{OH})$ & Detroit \\
\hline 14) Indiana & Indiana (except Lake and Porter Counties) & Indianapolis \\
\hline 15) Illinois & $\begin{array}{l}\text { Illinois (except three counties adjacent to } \\
\text { St. Louis, MO); South Wisconsin; Lake } \\
\text { and Porter Counties (IN) }\end{array}$ & Chicago \\
\hline 16) North-Central States & $\begin{array}{l}\text { North Wisconsin; Minnesota; North } \\
\text { Dakota; South Dakota; Iowa; Nebraska }\end{array}$ & Minneapolis \\
\hline 17) South-Central States & $\begin{array}{l}\text { Missouri; Kansas; Oklahoma; Arkansas; } \\
\text { Western Tennessee; Madison, St. Clair, } \\
\text { Monroe Counties (IL) }\end{array}$ & St. Louis \\
\hline 18) Gulf District & Texas; Louisiana & Houston \\
\hline 19) Mountain District & Colorado; Wyoming & Denver \\
\hline 20) Pacific Southwest & Southern California; Arizona; New Mexico & Los Angeles \\
\hline 21) Pacific Central & Northern California; Nevada; Utah & San Francisco \\
\hline 22) Pacific Northwest & Washington; Oregon; Idaho; Montana & Seattle \\
\hline
\end{tabular}

Notes. List of the 22 TWI districts with their headquarters location. 
Table A2: Balancing Tests for Applicant Firms By Treatment Year

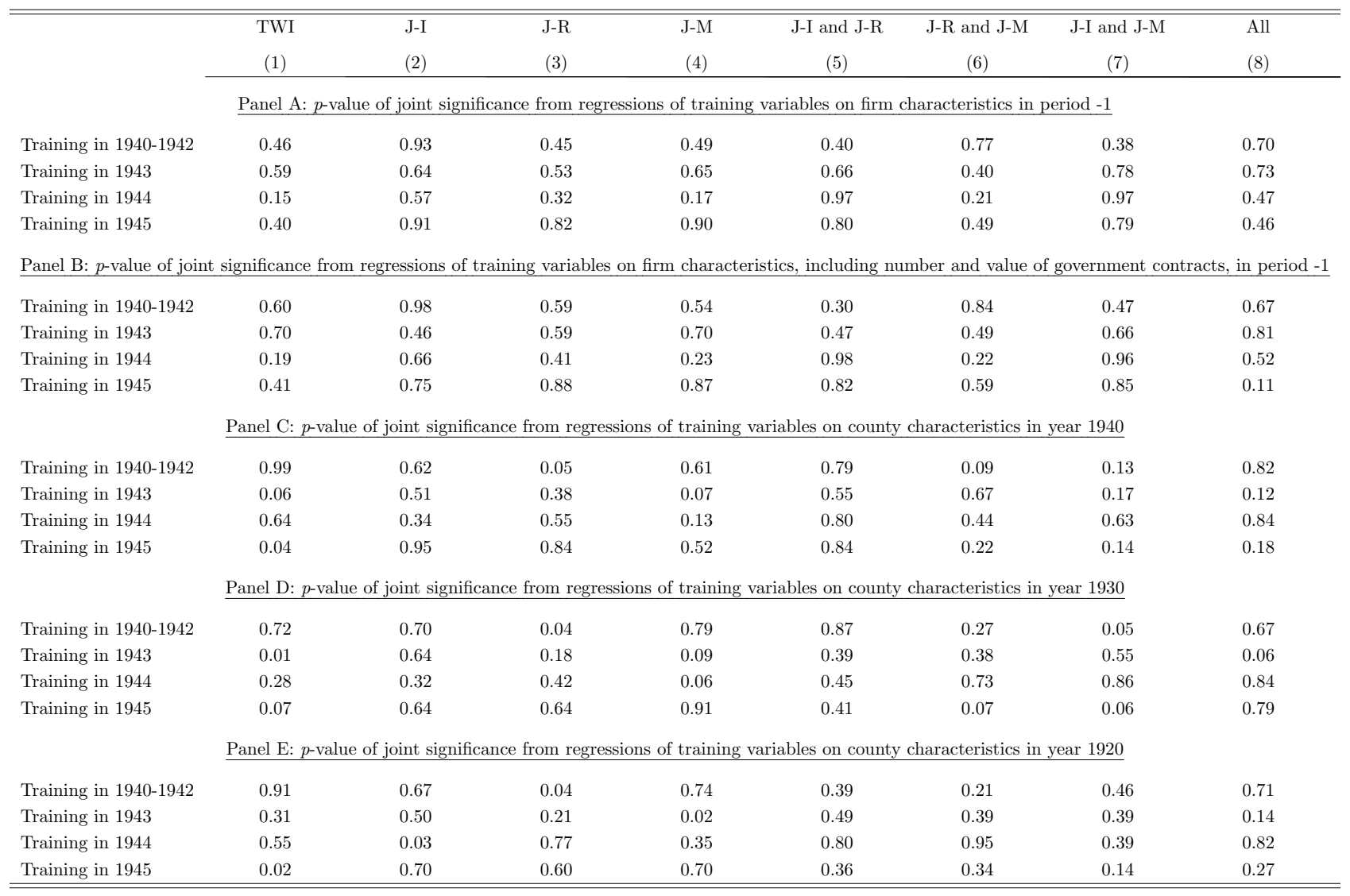

Notes. Panel A shows the $p$-value of the test of joint significance of the coefficients of fifteen firm characteristics observed in period -1 , distinguishing by training year. The variables are: the logs of sales, value added, number of employees, number of plants, foundation year, the value of inventory, capital, current assets, investments, number of workers' strikes, monetary compensation for workers' injuries, performance-based bonus payments, number of subsidiaries, as well as distance to the nearest railroad station and distance to the nearest port. Panel B adds the inverse hyperbolic sine function of the number and value of government contracts. The regressions also include fixed effects for countysector pairs, the application window, and the number of days between the opening of the window and the firm application. Panels C, D, and E show the $p$-value of the test of joint significance of the coefficients of several county characteristics measured in 1940,1930, and 1920, distinguishing by training year. The county-level variables are imputed to firms based on their location. These regressions include: $\log$ population, log of the manufacturing value added, log number of manufacturing establishments, $\log$ number of manufacturing employees, log average manufacturing wage, log total expenses in manufacturing, log value of manufacturing production, farms per capita, unemployment share (available only in 1930 and 1940), population per square mile, share of male residents, share of black population, share of urban population, share of illiterate population (available only in 1920 and 1930). County data are from IPUMS NHGIS, www.nhgis.org. The regressions also include fixed effects for subdistrict-sector pairs, the application window, and the number of days between the opening of the window and the firm application. Standard errors are clustered at the subdistrict-application window level. 
Table A3: Autocorrelation of the TWI Trainings

\begin{tabular}{|c|c|c|c|c|c|c|c|c|}
\hline & $\begin{array}{c}\mathrm{TWI}_{t} \\
(1)\end{array}$ & $\begin{array}{l}\mathrm{J}-\mathrm{I}_{t} \\
(2) \\
\end{array}$ & $\begin{array}{c}\mathrm{J}-\mathrm{R}_{t} \\
(3)\end{array}$ & $\begin{array}{c}\mathrm{J}-\mathrm{M}_{t} \\
(4)\end{array}$ & $\begin{array}{c}\text { J-I and J-R } \\
(5)\end{array}$ & $\begin{array}{c}\mathrm{J}-\mathrm{I} \text { and } \mathrm{J}-\mathrm{M}_{t} \\
(6)\end{array}$ & $\begin{array}{c}\mathrm{J}-\mathrm{R} \text { and } \mathrm{J}-\mathrm{M}_{t} \\
(7)\end{array}$ & $\begin{array}{c}\mathrm{All}_{t} \\
(8)\end{array}$ \\
\hline $\mathrm{TWI}_{t-1}$ & $\begin{array}{c}0.028 \\
(0.022)\end{array}$ & & & & & & & \\
\hline $\mathrm{J}-\mathrm{I}_{t-1}$ & & $\begin{array}{c}0.039 \\
(0.028)\end{array}$ & & & & & & \\
\hline $\mathrm{J}-\mathrm{R}_{t-1}$ & & & $\begin{array}{c}-0.020^{* *} \\
(0.010)\end{array}$ & & & & & \\
\hline $\mathrm{J}-\mathrm{M}_{t-1}$ & & & & $\begin{array}{c}0.007 \\
(0.028)\end{array}$ & & & & \\
\hline $\mathrm{J}-\mathrm{I}$ and $\mathrm{J}-\mathrm{R}_{t-1}$ & & & & & $\begin{array}{c}0.002 \\
(0.023)\end{array}$ & & & \\
\hline $\mathrm{J}-\mathrm{I}$ and $\mathrm{J}-\mathrm{M}_{t-1}$ & & & & & & $\begin{array}{c}0.001 \\
(0.022)\end{array}$ & & \\
\hline $\mathrm{J}-\mathrm{R}$ and $\mathrm{J}-\mathrm{M}_{t-1}$ & & & & & & & $\begin{array}{c}0.007 \\
(0.019)\end{array}$ & \\
\hline $\mathrm{All}_{t-1}$ & & & & & & & & $\begin{array}{r}0.017 \\
(0.024)\end{array}$ \\
\hline Observations & 1,873 & 1,873 & 1,873 & 1,873 & 1,873 & 1,873 & 1,873 & 1,873 \\
\hline $\mathrm{R}^{2}$ & 0.001 & 0.002 & 0.001 & 0.001 & 0.001 & 0.001 & 0.001 & 0.001 \\
\hline
\end{tabular}

Notes. This table shows the autocorrelation between the current and past share of firms that received different types of TWI trainings. The unit of observation is one of 364 subdistricts and one of 10 application windows. The standard errors are clustered at the subdistrict level. ${ }^{* * *} \mathrm{p}<0.01,{ }^{* *} \mathrm{p}<0.05$, $* \mathrm{p}<0.1$.

Table A4: Exit Regressions

\begin{tabular}{lcccccc}
\hline \hline & Exit & Exit & Exit & Exit & Exit & Exit \\
& $(1)$ & $(2)$ & $(3)$ & $(4)$ & $(5)$ & $(6)$ \\
\cline { 2 - 7 } TWI & $-0.257^{* * *}$ & $-0.249^{* * *}$ & $-0.254^{* * *}$ & & & \\
J-I & $(0.013)$ & $(0.012)$ & $(0.013)$ & & & \\
& & & & $-0.221^{* * *}$ & $-0.223^{* * *}$ & $-0.225^{* * *}$ \\
J-R & & & $(0.019)$ & $(0.017)$ & $(0.018)$ \\
& & & $-0.258^{* * *}$ & $-0.242^{* * *}$ & $-0.245^{* * *}$ \\
J-M & & & $(0.019)$ & $(0.017)$ & $(0.019)$ \\
& & & $-0.288^{* * *}$ & $-0.280^{* * *}$ & $-0.288^{* * *}$ \\
Observations & 6,244 & 6,244 & 6,115 & $(0.017)$ & $(0.015)$ & $(0.017)$ \\
$\mathrm{R}^{2}$ & 0.172 & 0.090 & 0.152 & 0,244 & 6,244 & 6,115 \\
County-sector FEs & Yes & No & No & Yes & 0.090 & 0.153 \\
District-sector FEs & No & Yes & No & No & Yes & No \\
Subdistrict-sector FEs & No & No & Yes & No & No & Yes \\
App. window FEs & Yes & Yes & Yes & Yes & Yes & Yes \\
\hline \hline
\end{tabular}

Notes. Exit is equal to one for firms that exited the sample between period -5 and period 10 . The standard errors are clustered at the level of subdistricts and application windows. $* * * \mathrm{p}<0.01$, ** $\mathrm{p}<0.05,{ }^{*} \mathrm{p}<0.1$. 
Table A5: Components of Production Function

\begin{tabular}{lccccc}
\hline \hline & TFP & Log sales & $\begin{array}{c}\text { Log intermediate } \\
\text { inputs }\end{array}$ & Log capital & Log employees \\
& $(1)$ & $(2)$ & $(3)$ & $(4)$ & $(5)$ \\
\cline { 2 - 5 } TWI x Post & $0.159^{* * *}$ & $0.128^{* * *}$ & $-0.079^{* * *}$ & $-0.013^{* * *}$ & $0.060^{* * *}$ \\
& $(0.004)$ & $(0.006)$ & $(0.002)$ & $(0.002)$ & $(0.002)$ \\
Observations & 67,472 & 67,472 & 67,472 & 67,472 & 67,472 \\
$\mathrm{R}^{2}$ & 0.326 & 0.184 & 0.391 & 0.426 & 0.148 \\
\hline \hline
\end{tabular}

Notes. This table shows the treatment effects for the different components of the production function. The distance from the TWI intervention for the nontreated firms is imputed using the distance from the TWI intervention of the first participating firm in the same subdistrict and application window. The sample includes applicant firms that either received only one TWI training or no training at all. The standard errors are clustered at the level of subdistricts and application windows. ${ }^{* * *} \mathrm{p}<0.01, * *$ $\mathrm{p}<0.05,{ }^{*} \mathrm{p}<0.1$.

Table A6: Changes in Firm Structure

\begin{tabular}{lccccc}
\hline \hline & Log plants & Log employees & Log managers & Log subsidiaries & Log investment \\
& $(1)$ & $(2)$ & $(3)$ & $(4)$ & $(5)$ \\
\cline { 2 - 5 } TWI x Period 1 & $0.001^{* * *}$ & $0.012^{* * *}$ & 0.012 & -0.009 & $0.062^{* *}$ \\
TWI x Period 5 & $(0.000)$ & $(0.001)$ & $(0.008)$ & $(0.009)$ & $(0.026)$ \\
& $0.026^{* * *}$ & $0.072^{* * *}$ & $0.050^{* * *}$ & $0.016^{*}$ & $0.155^{* * *}$ \\
TWI x Period 10 & $(0.002)$ & $(0.002)$ & $(0.008)$ & $(0.009)$ & $(0.025)$ \\
& $0.062^{* * *}$ & $0.127^{* * *}$ & $0.108^{* * *}$ & $0.050^{* * *}$ & $0.168^{* * *}$ \\
Observations & $(0.003)$ & $(0.003)$ & $(0.008)$ & $(0.010)$ & $(0.028)$ \\
$\mathrm{R}^{2}$ & & & & 67,472 & 67,472 \\
\hline \hline
\end{tabular}

Notes. This table shows the coefficients of the interactions between the training variable and three selected period dummies (out of 15 period dummies included). The omitted period is the year before the TWI training (period -1). The distance from the TWI intervention for the nontreated firms is imputed using the distance from the TWI intervention of the first participating firm in the same subdistrict and application window. The sample includes applicant firms that either received only one TWI training or no training at all. The standard errors are clustered at the level of subdistricts and application windows. ${ }^{* * *} \mathrm{p}<0.01,{ }^{* *} \mathrm{p}<0.05,{ }^{*} \mathrm{p}<0.1$. 
Table A7: Matching Trained and Nontrained firms

\begin{tabular}{|c|c|c|c|c|c|c|c|c|}
\hline & $\begin{array}{c}\text { Log sales } \\
(1)\end{array}$ & $\begin{array}{l}\text { TFP } \\
(2) \\
\end{array}$ & $\begin{array}{c}\log \mathrm{ROA} \\
(3) \\
\end{array}$ & $\begin{array}{c}\text { Log plants } \\
(4)\end{array}$ & $\begin{array}{c}\text { Log employees } \\
(5) \\
\end{array}$ & $\begin{array}{c}\text { Log managers } \\
(6) \\
\end{array}$ & $\begin{array}{c}\text { Log subsidiaries } \\
(7)\end{array}$ & $\begin{array}{c}\text { Log investment } \\
(8) \\
\end{array}$ \\
\hline \multicolumn{9}{|c|}{ Panel A: Unmatched baseline } \\
\hline TWI x Post & $\begin{array}{c}0.128^{* * *} \\
(0.006)\end{array}$ & $\begin{array}{c}0.159^{* * *} \\
(0.004)\end{array}$ & $\begin{array}{c}0.065^{* * *} \\
(0.004)\end{array}$ & $\begin{array}{c}0.028^{* * *} \\
(0.001)\end{array}$ & $\begin{array}{c}0.060^{* * *} \\
(0.002)\end{array}$ & $\begin{array}{c}0.057^{* * *} \\
(0.004)\end{array}$ & $\begin{array}{c}0.017 * * * \\
(0.003)\end{array}$ & $\begin{array}{c}0.134^{* * *} \\
(0.011)\end{array}$ \\
\hline Observations & 67,472 & 67,472 & 67,472 & 67,472 & 67,472 & 67,472 & 67,472 & 67,472 \\
\hline \multicolumn{9}{|c|}{ Panel B: Matching using nine variables observed at -1} \\
\hline TWI x Post & $\begin{array}{c}0.127^{* * *} \\
(0.006)\end{array}$ & $\begin{array}{c}0.159^{* * *} \\
(0.005)\end{array}$ & $\begin{array}{c}0.065^{* * *} \\
(0.004)\end{array}$ & $\begin{array}{c}0.028^{* * *} \\
(0.001)\end{array}$ & $\begin{array}{c}0.060^{* * *} \\
(0.002)\end{array}$ & $\begin{array}{c}0.057^{* * *} \\
(0.004)\end{array}$ & $\begin{array}{c}0.017^{* * * *} \\
(0.004)\end{array}$ & $\begin{array}{c}0.133^{* * *} \\
(0.012)\end{array}$ \\
\hline Observations & 66,048 & 66,048 & 66,048 & 66,048 & 66,048 & 66,048 & 66,048 & 66,048 \\
\hline \multicolumn{9}{|c|}{ Panel C: Matching using nine variables observed between -5 and $-1+$ period FEs } \\
\hline TWI $x$ Post & $\begin{array}{c}0.143^{* * *} \\
(0.006)\end{array}$ & $\begin{array}{c}0.169^{* * * *} \\
(0.005)\end{array}$ & $\begin{array}{c}0.065 * * * \\
(0.004)\end{array}$ & $\begin{array}{c}0.028^{* * *} \\
(0.002)\end{array}$ & $\begin{array}{c}0.060^{* * *} \\
(0.002)\end{array}$ & $\begin{array}{c}0.058 * * * \\
(0.004)\end{array}$ & $\begin{array}{c}0.017 * * * \\
(0.004)\end{array}$ & $\begin{array}{c}0.145^{* * *} \\
(0.012)\end{array}$ \\
\hline Observations & 64,080 & 64,080 & 64,080 & 64,080 & 64,080 & 64,080 & 64,080 & 64,080 \\
\hline \multicolumn{9}{|c|}{ Panel D: Matching using eighteen variables observed at -1} \\
\hline TWI x Post & $\begin{array}{c}0.130^{* * *} \\
(0.006)\end{array}$ & $\begin{array}{c}0.160^{* * * *} \\
(0.005)\end{array}$ & $\begin{array}{c}0.065^{* * *} \\
(0.004)\end{array}$ & $\begin{array}{c}0.028^{* * *} \\
(0.001)\end{array}$ & $\begin{array}{c}0.060^{* * *} \\
(0.002)\end{array}$ & $\begin{array}{c}0.057^{* * *} \\
(0.004)\end{array}$ & $\begin{array}{c}0.017^{* * *} \\
(0.004)\end{array}$ & $\begin{array}{c}0.136^{* * *} \\
(0.012)\end{array}$ \\
\hline Observations & 65,824 & 65,824 & 65,824 & 65,824 & 65,824 & 65,824 & 65,824 & 65,824 \\
\hline \multicolumn{9}{|c|}{ Panel E: Matching using eighteen variables observed at $-1+$ district FEs } \\
\hline TWI x Post & $\begin{array}{c}0.130^{* * *} \\
(0.006)\end{array}$ & $\begin{array}{c}0.160^{* * *} \\
(0.005)\end{array}$ & $\begin{array}{c}0.064^{* * *} \\
(0.004)\end{array}$ & $\begin{array}{c}0.029^{* * *} \\
(0.001)\end{array}$ & $\begin{array}{c}0.060^{* * *} \\
(0.002)\end{array}$ & $\begin{array}{c}0.055^{* * *} \\
(0.004)\end{array}$ & $\begin{array}{c}0.016^{* * *} \\
(0.004)\end{array}$ & $\begin{array}{c}0.135 * * * \\
(0.012)\end{array}$ \\
\hline Observations & 65,808 & 65,808 & 65,808 & 65,808 & 65,808 & 65,808 & 65,808 & 65,808 \\
\hline \multicolumn{9}{|c|}{ Panel F: Matching using eighteen variables observed at $-1+$ subdistrict FEs } \\
\hline TWI x Post & $\begin{array}{c}0.128^{* * *} \\
(0.006)\end{array}$ & $\begin{array}{c}0.160^{* * * *} \\
(0.005)\end{array}$ & $\begin{array}{c}0.066^{* * *} \\
(0.004)\end{array}$ & $\begin{array}{c}0.028^{* * *} \\
(0.001)\end{array}$ & $\begin{array}{c}0.060^{* * *} \\
(0.002)\end{array}$ & $\begin{array}{c}0.058^{* * *} \\
(0.004)\end{array}$ & $\begin{array}{c}0.019 * * * \\
(0.004)\end{array}$ & $\begin{array}{c}0.135^{* * *} \\
(0.012)\end{array}$ \\
\hline Observations & 65,776 & 65,776 & 65,776 & 65,776 & 65,776 & 65,776 & 65,776 & 65,776 \\
\hline \multicolumn{9}{|c|}{ Panel G: Matching using eighteen variables observed at $-1+$ subdistrict FEs \& app. window FEs } \\
\hline TWI x Post & $\begin{array}{c}0.133^{* * *} \\
(0.006)\end{array}$ & $\begin{array}{c}0.161^{* * *} \\
(0.005)\end{array}$ & $\begin{array}{c}0.062^{* * *} \\
(0.004)\end{array}$ & $\begin{array}{c}0.027^{* * * *} \\
(0.002)\end{array}$ & $\begin{array}{c}0.060^{* * *} \\
(0.002)\end{array}$ & $\begin{array}{c}0.057^{* * *} \\
(0.004)\end{array}$ & $\begin{array}{c}0.017^{* * *} \\
(0.004)\end{array}$ & $\begin{array}{c}0.133^{* * *} \\
(0.012)\end{array}$ \\
\hline Observations & 65,696 & 65,696 & 65,696 & 65,696 & 65,696 & 65,696 & 65,696 & 65,696 \\
\hline
\end{tabular}

Notes. This table shows the results of different propensity score matching (PSM) between trained and nontrained firms. All PSM algorithms impose a common support and match without replacement: we use the Stata command psmatch2 with options common, ties, noreplacement, descending. In panel B, we match using nine variables observed in period -1: number of plants, number of employees, sales, TFP, distance from the nearest port and railroad station, and three sector dummies. In panel $\mathrm{C}$, we match using the same nine variables observed between period -5 and period -1 , also including period fixed effects. In panel $\mathrm{D}$, we match using eighteen variables observed in period -1: number of plants, number of employees, sales, TFP, distance from the nearest port and railroad station, three sector dummies, foundation year, value of inventory, capital, value of current assets, investments, number of strikes, money spent for worker injuries, money spent for bonuses, number of subsidiaries. In panel $\mathrm{E}$, we match using the same eighteen variables observed in period -1 , as well as district fixed effects. In panel $\mathrm{F}$, we match using the same eighteen variables observed in period -1 , as well as subdistrict fixed effects. In panel $\mathrm{G}$, we match using the same eighteen variables observed in period -1 , as well as subdistrict and application window fixed effects. The coefficients of the PSM regressions are included in Table B3. The distance from the TWI intervention for the nontreated firms is imputed using the distance from the TWI intervention of the first participating firm in the same subdistrict and application window. The sample includes applicant firms that either received only one TWI training or no training at all. The standard errors are clustered at the level of subdistricts and application windows. ${ }^{* * *} \mathrm{p}<0.01,{ }^{* *} \mathrm{p}<0.05,{ }^{*} \mathrm{p}<0.1$. 
Table A8: Effects of TWI Training on Responses to TWI Surveys

\begin{tabular}{|c|c|c|c|c|c|c|}
\hline & \multicolumn{2}{|c|}{ J-I } & \multicolumn{2}{|c|}{ J-R } & \multicolumn{2}{|c|}{$\mathrm{J}-\mathrm{M}$} \\
\hline & $\begin{array}{c}\text { Period } 0 \\
(1)\end{array}$ & $\begin{array}{c}\text { Period } 3 \\
(2)\end{array}$ & $\begin{array}{l}\text { Period } 0 \\
\quad(3)\end{array}$ & $\begin{array}{c}\text { Period } 3 \\
\text { (4) }\end{array}$ & $\begin{array}{l}\text { Period } 0 \\
\quad(5)\end{array}$ & $\begin{array}{c}\text { Period } 3 \\
(6)\end{array}$ \\
\hline (1) Log machine repairs & $\begin{array}{c}-0.089^{* * *} \\
(0.001)\end{array}$ & $\begin{array}{c}-0.357^{* * *} \\
(0.006)\end{array}$ & $\begin{array}{c}0.053^{* * *} \\
(0.001)\end{array}$ & $\begin{array}{c}0.216^{* * *} \\
(0.004)\end{array}$ & $\begin{array}{c}0.053^{* * *} \\
(0.001)\end{array}$ & $\begin{array}{c}0.219 * * * \\
(0.004)\end{array}$ \\
\hline (2) Log workers' injuries & $\begin{array}{c}0.029^{* * *} \\
(0.001)\end{array}$ & $\begin{array}{c}0.118^{* * *} \\
(0.004)\end{array}$ & $\begin{array}{c}0.125^{* * *} \\
(0.004)\end{array}$ & $\begin{array}{c}0.029^{* * *} \\
(0.001)\end{array}$ & $\begin{array}{c}0.030^{* * *} \\
(0.000)\end{array}$ & $\begin{array}{c}0.121^{* * *} \\
(0.005)\end{array}$ \\
\hline (3) Register causes of breakdown & $\begin{array}{c}0.877^{* * *} \\
(0.009)\end{array}$ & $\begin{array}{c}0.877^{* * *} \\
(0.020)\end{array}$ & $\begin{array}{c}-0.019 * * * \\
(0.006)\end{array}$ & $\begin{array}{c}-0.018^{* * *} \\
(0.007)\end{array}$ & $\begin{array}{c}-0.020^{* * *} \\
(0.007)\end{array}$ & $\begin{array}{c}-0.016^{* * *} \\
(0.006)\end{array}$ \\
\hline (4) Job description for managers & $\begin{array}{c}0.001 \\
(0.001)\end{array}$ & $\begin{array}{c}0.001 \\
(0.002)\end{array}$ & $\begin{array}{c}0.876^{* * *} \\
(0.006)\end{array}$ & $\begin{array}{c}0.875^{* * *} \\
(0.019)\end{array}$ & $\begin{array}{l}-0.002 \\
(0.002)\end{array}$ & $\begin{array}{l}-0.002 \\
(0.003)\end{array}$ \\
\hline (5) Job description for workers & $\begin{array}{c}-0.019^{* * *} \\
(0.007)\end{array}$ & $\begin{array}{c}-0.020^{* *} \\
(0.008)\end{array}$ & $\begin{array}{c}0.838^{* * *} \\
(0.008)\end{array}$ & $\begin{array}{c}0.826^{* * *} \\
(0.021)\end{array}$ & $\begin{array}{c}-0.015^{* * *} \\
(0.005)\end{array}$ & $\begin{array}{c}-0.014^{* *} \\
(0.006)\end{array}$ \\
\hline (6) Training for workers & $\begin{array}{c}-0.025^{* * *} \\
(0.007)\end{array}$ & $\begin{array}{c}-0.030^{* * *} \\
(0.009)\end{array}$ & $\begin{array}{c}0.875^{* * *} \\
(0.008)\end{array}$ & $\begin{array}{c}0.875^{* * *} \\
(0.017)\end{array}$ & $\begin{array}{c}-0.015^{* * *} \\
(0.005)\end{array}$ & $\begin{array}{c}-0.013^{* *} \\
(0.006)\end{array}$ \\
\hline (7) Bonus payment scheme & $\begin{array}{c}-0.008^{*} \\
(0.004)\end{array}$ & $\begin{array}{l}-0.009 \\
(0.006)\end{array}$ & $\begin{array}{c}0.897^{* * *} \\
(0.006)\end{array}$ & $\begin{array}{c}0.902^{* * *} \\
(0.015)\end{array}$ & $\begin{array}{c}-0.007^{*} \\
(0.004)\end{array}$ & $\begin{array}{l}-0.006 \\
(0.004)\end{array}$ \\
\hline (8) Suggestions from workers & $\begin{array}{c}0.001 \\
(0.001)\end{array}$ & $\begin{array}{c}-0.002 \\
(0.003)\end{array}$ & $\begin{array}{c}0.563^{* * *} \\
(0.010)\end{array}$ & $\begin{array}{c}0.552^{* * *} \\
(0.026)\end{array}$ & $\begin{array}{c}-0.002 \\
(0.002)\end{array}$ & $\begin{array}{l}-0.003 \\
(0.004)\end{array}$ \\
\hline (9) Log unused input & $\begin{array}{c}0.039^{* * *} \\
(0.001)\end{array}$ & $\begin{array}{c}0.157^{* * *} \\
(0.004)\end{array}$ & $\begin{array}{c}0.039^{* * *} \\
(0.001)\end{array}$ & $\begin{array}{c}0.158^{* * *} \\
(0.004)\end{array}$ & $\begin{array}{c}-0.089^{* * *} \\
(0.000)\end{array}$ & $\begin{array}{c}-0.348^{* * *} \\
(0.004)\end{array}$ \\
\hline (10) Production planning & $\begin{array}{c}-0.027^{* * *} \\
(0.008)\end{array}$ & $\begin{array}{c}-0.032^{* * *} \\
(0.009)\end{array}$ & $\begin{array}{c}-0.018^{* *} \\
(0.007)\end{array}$ & $\begin{array}{c}-0.019^{* *} \\
(0.008)\end{array}$ & $\begin{array}{c}0.823^{* * *} \\
(0.009)\end{array}$ & $\begin{array}{c}0.827^{* * *} \\
(0.023)\end{array}$ \\
\hline (11) Marketing & $\begin{array}{c}-0.008^{*} \\
(0.004)\end{array}$ & $\begin{array}{l}-0.007 \\
(0.006)\end{array}$ & $\begin{array}{l}-0.002 \\
(0.002)\end{array}$ & $\begin{array}{l}-0.001 \\
(0.003)\end{array}$ & $\begin{array}{c}0.840^{* * *} \\
(0.008)\end{array}$ & $\begin{array}{c}0.828^{* * *} \\
(0.020)\end{array}$ \\
\hline
\end{tabular}

Notes. The data used in this table come from the surveys administered by the TWI administration only to firms that received at least one training. The responses were collected before the training, three months after the training, and then each year until 1945. Each row represents a separate regression whose dependent variable is one of the 11 management practices listed in the first column. The estimates are coefficients that measure the difference between each period and the period just before the implementation of the TWI program (period -1), separately for each TWI training. The regressions also include the coefficients for period 1 and 2 , the treatment variables in isolation, as well as fixed effects for county-sector pairs, the application window, and the number of days between the opening of the window and the firm application. Three dependent variables are continuous and transformed in logs: the number of machine repairs (1); the number of workers' injuries (2); and the value of unused input in the inventory (9). The other eight variables are dummies equal to 1 if the firm was implementing a given management practice: keeping records of machine breakdowns (3); providing clear list of tasks and expectations to managers (4) and workers (5); offering on-the-job training (6); implementing bonus payment schemes (7); allowing workers to provide suggestions (8); using formal production planning (10); having a formal marketing unit (11). Standard errors are clustered at the level of subdistricts and application windows. ${ }^{* * *} \mathrm{p}<0.01,{ }^{*} \mathrm{p}<0.05, * \mathrm{p}<0.1$. 
Table A9: Clustering Standard Errors at Subdistrict Level

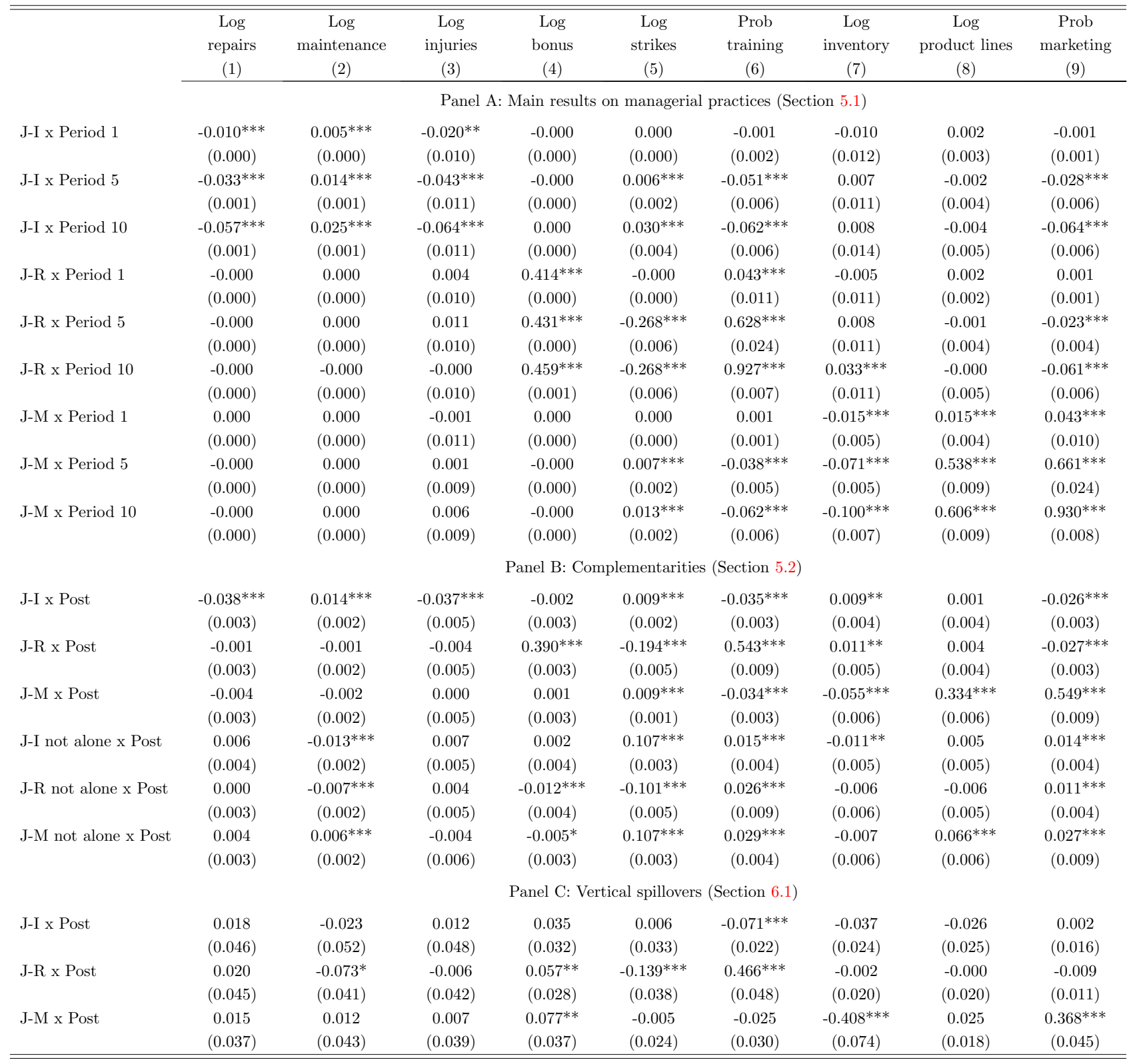

Notes: This table shows that the main findings on managerial practices are robust to clustering the standard errors at the subdistrict level. Panel A tests the robustness of the main results on managerial practices described in Section 5.1 and Table 3. Panel B tests the robustness of the results on complementarities described in Section 5.2 and Table 4. Panel $\mathrm{C}$ tests the robustness of the results on vertical spillovers described in Section 6.1 and Table 5 (Panel A). 
Table A10: Multiple Hypotheses Testing

\begin{tabular}{|c|c|c|c|c|c|c|c|c|c|}
\hline & $\begin{array}{c}\text { Log } \\
\text { repairs } \\
(1) \\
\end{array}$ & $\begin{array}{c}\log \\
\text { maintenance } \\
(2) \\
\end{array}$ & $\begin{array}{c}\log \\
\text { injuries } \\
(3) \\
\end{array}$ & $\begin{array}{c}\log \\
\text { bonus } \\
(4) \\
\end{array}$ & $\begin{array}{c}\log \\
\text { strikes } \\
(5) \\
\end{array}$ & $\begin{array}{c}\text { Prob } \\
\text { training } \\
(6)\end{array}$ & $\begin{array}{c}\log \\
\text { inventory } \\
(7)\end{array}$ & $\begin{array}{c}\text { Log } \\
\text { product lines } \\
(8)\end{array}$ & $\begin{array}{c}\text { Prob } \\
\text { marketing } \\
(9)\end{array}$ \\
\hline & \multicolumn{9}{|c|}{ Panel A: Main results on managerial practices (Section 5.1) } \\
\hline J-I x Period 1 & 0.18 & 0.18 & 0.52 & 0.82 & 0.84 & 0.90 & 0.84 & 0.84 & 0.90 \\
\hline J-I x Period 5 & $<0.01$ & $<0.01$ & $<0.01$ & 0.94 & $<0.01$ & $<0.01$ & 0.94 & 0.94 & $<0.01$ \\
\hline J-I x Period 10 & $<0.01$ & $<0.01$ & $<0.01$ & 0.86 & $<0.01$ & $<0.01$ & 0.86 & 0.80 & $<0.01$ \\
\hline J-R $x$ Period 1 & 0.88 & 0.88 & 0.94 & 0.18 & 0.90 & 0.18 & 0.94 & 0.94 & 0.58 \\
\hline J-R $x$ Period 5 & 0.88 & 0.88 & 0.72 & $<0.01$ & $<0.01$ & $<0.01$ & 0.84 & 0.88 & $<0.01$ \\
\hline J-R $x$ Period 10 & 0.88 & 0.44 & 0.98 & $<0.01$ & $<0.01$ & $<0.01$ & $<0.01$ & 0.98 & $<0.01$ \\
\hline J-M x Period 1 & 1 & 0.98 & 1 & 1 & 0.90 & 0.98 & 0.26 & 0.24 & 0.24 \\
\hline J-M x Period 5 & 0.90 & 0.76 & 0.98 & 0.90 & $<0.01$ & $<0.01$ & $<0.01$ & $<0.01$ & $<0.01$ \\
\hline \multirow[t]{2}{*}{$\mathrm{J}-\mathrm{M}$ x Period 10} & 0.82 & 0.64 & 0.82 & 0.64 & $<0.01$ & $<0.01$ & $<0.01$ & $<0.01$ & $<0.01$ \\
\hline & \multicolumn{9}{|c|}{ Panel B: Complementarities (Section 5.2) } \\
\hline J-I x Post & $<0.01$ & $<0.01$ & $<0.01$ & 0.64 & $<0.01$ & $<0.01$ & 0.08 & 0.80 & $<0.01$ \\
\hline J-R $x$ Post & 0.86 & 0.80 & 0.74 & $<0.01$ & $<0.01$ & $<0.01$ & 0.08 & 0.74 & $<0.01$ \\
\hline J-M x Post & 0.40 & 0.72 & 0.96 & 0.84 & $<0.01$ & $<0.01$ & $<0.01$ & $<0.01$ & $<0.01$ \\
\hline J-I not alone $\mathrm{x}$ Post & 0.24 & $<0.01$ & 0.36 & 0.52 & $<0.01$ & $<0.01$ & 0.06 & 0.52 & $<0.01$ \\
\hline J-R not alone $\mathrm{x}$ Post & 0.86 & $<0.01$ & 0.68 & $<0.01$ & $<0.01$ & $<0.01$ & 0.58 & 0.58 & $<0.01$ \\
\hline \multirow[t]{2}{*}{ J-M not alone $\mathrm{x}$ Post } & 0.52 & $<0.01$ & 0.52 & 0.36 & $<0.01$ & $<0.01$ & 0.52 & $<0.01$ & $<0.01$ \\
\hline & \multicolumn{9}{|c|}{ Panel C: Vertical spillovers (Section 6.1) } \\
\hline J-I x Post & 1 & 1 & 1 & 0.86 & 1 & 0.02 & 0.80 & 0.86 & 1 \\
\hline J-R $x$ Post & 1 & 0.42 & 0.92 & 0.30 & $<0.01$ & $<0.01$ & 1 & 1 & 0.90 \\
\hline J-M x Post & 1 & 1 & 1 & 0.20 & 1 & 0.90 & $<0.01$ & 0.54 & $<0.01$ \\
\hline
\end{tabular}

Notes: This table shows p-values adjusted for multiple concurrent hypotheses tests using the Westfall-Young methodology ("Resampling-based Multiple Testing: Examples and Methods for pvalue Adjustment." by Westfall and Young, 1993). The table uses the Stata command wyoung. Panel A tests the robustness of the main results on managerial practices described in Section 5.1 and Table 3. Panel B tests the robustness of the results on complementarities described in Section 5.2 and Table 4. Panel $\mathrm{C}$ tests the robustness of the results on vertical spillovers described in Section 6.1 and Table 5 (Panel A). 
Table A11: Complementarity Effects, Alternative Specification 1

\begin{tabular}{|c|c|c|c|c|c|c|c|c|c|}
\hline & $\begin{array}{l}\text { Log } \\
\text { repairs } \\
(1) \\
\end{array}$ & $\begin{array}{c}\log \\
\text { maintenance } \\
(2)\end{array}$ & $\begin{array}{c}\log \\
\text { injuries } \\
(3) \\
\end{array}$ & $\begin{array}{c}\text { Log } \\
\text { bonus } \\
(4) \\
\end{array}$ & $\begin{array}{c}\log \\
\text { strikes } \\
(5) \\
\end{array}$ & $\begin{array}{c}\text { Prob } \\
\text { training } \\
(6)\end{array}$ & $\begin{array}{c}\log \\
\text { inventory } \\
(7)\end{array}$ & $\begin{array}{c}\text { Log } \\
\text { product lines } \\
(8)\end{array}$ & $\begin{array}{c}\text { Prob } \\
\text { marketing } \\
(9)\end{array}$ \\
\hline J-I x Post & $\begin{array}{c}-0.037^{* * *} \\
(0.003)\end{array}$ & $\begin{array}{c}0.014^{* * *} \\
(0.002)\end{array}$ & $\begin{array}{c}-0.037^{* * *} \\
(0.005)\end{array}$ & $\begin{array}{l}-0.001 \\
(0.003)\end{array}$ & $\begin{array}{c}0.008 * * * \\
(0.002)\end{array}$ & $\begin{array}{c}-0.038^{* * *} \\
(0.003)\end{array}$ & $\begin{array}{c}0.009^{* *} \\
(0.004)\end{array}$ & $\begin{array}{l}-0.000 \\
(0.004)\end{array}$ & $\begin{array}{c}-0.025^{* * *} \\
(0.003)\end{array}$ \\
\hline J-R $\times$ Post & $\begin{array}{l}-0.000 \\
(0.003)\end{array}$ & $\begin{array}{l}-0.001 \\
(0.002)\end{array}$ & $\begin{array}{l}-0.003 \\
(0.005)\end{array}$ & $\begin{array}{c}0.390^{* * *} \\
(0.003)\end{array}$ & $\begin{array}{c}-0.195^{* * *} \\
(0.004)\end{array}$ & $\begin{array}{c}0.540^{* * *} \\
(0.008)\end{array}$ & $\begin{array}{c}0.011^{* * *} \\
(0.004)\end{array}$ & $\begin{array}{c}0.002 \\
(0.004)\end{array}$ & $\begin{array}{c}-0.026^{* * *} \\
(0.003)\end{array}$ \\
\hline J-M x Post & $\begin{array}{l}-0.004 \\
(0.003)\end{array}$ & $\begin{array}{l}-0.001 \\
(0.002)\end{array}$ & $\begin{array}{c}0.001 \\
(0.005)\end{array}$ & $\begin{array}{c}0.002 \\
(0.003)\end{array}$ & $\begin{array}{c}0.008^{* * *} \\
(0.001)\end{array}$ & $\begin{array}{c}-0.038^{* * *} \\
(0.003)\end{array}$ & $\begin{array}{c}-0.055^{* * *} \\
(0.006)\end{array}$ & $\begin{array}{c}0.332^{* * *} \\
(0.006)\end{array}$ & $\begin{array}{c}0.550^{* * *} \\
(0.008)\end{array}$ \\
\hline J-I and J-R $x$ Post & $\begin{array}{c}-0.031^{* * * *} \\
(0.002)\end{array}$ & $\begin{array}{c}-0.005^{* * *} \\
(0.001)\end{array}$ & $\begin{array}{c}-0.028^{* * *} \\
(0.003)\end{array}$ & $\begin{array}{c}0.380^{* * *} \\
(0.002)\end{array}$ & $\begin{array}{c}-0.183^{* * *} \\
(0.003)\end{array}$ & $\begin{array}{c}0.538^{* * *} \\
(0.006)\end{array}$ & $\begin{array}{c}0.004 \\
(0.003)\end{array}$ & $\begin{array}{l}-0.002 \\
(0.002)\end{array}$ & $\begin{array}{c}-0.025^{* * *} \\
(0.002)\end{array}$ \\
\hline J-R and J-M x Post & $\begin{array}{l}-0.000 \\
(0.002)\end{array}$ & $\begin{array}{l}-0.002 \\
(0.001)\end{array}$ & $\begin{array}{l}-0.002 \\
(0.003)\end{array}$ & $\begin{array}{c}0.376^{* * *} \\
(0.002)\end{array}$ & $\begin{array}{c}-0.183^{* * *} \\
(0.003)\end{array}$ & $\begin{array}{c}0.552^{* * *} \\
(0.005)\end{array}$ & $\begin{array}{c}-0.056^{* * *} \\
(0.004)\end{array}$ & $\begin{array}{c}0.392^{* * *} \\
(0.004)\end{array}$ & $\begin{array}{c}0.563^{* * *} \\
(0.005)\end{array}$ \\
\hline J-M and J-I x Post & $\begin{array}{c}-0.032^{* * *} \\
(0.002)\end{array}$ & $\begin{array}{c}0.007^{* * * *} \\
(0.001)\end{array}$ & $\begin{array}{c}-0.032 * * * \\
(0.003)\end{array}$ & $\begin{array}{l}-0.001 \\
(0.002)\end{array}$ & $\begin{array}{c}0.228^{* * *} \\
(0.003)\end{array}$ & $\begin{array}{c}-0.037^{* * *} \\
(0.003)\end{array}$ & $\begin{array}{c}-0.064^{* * *} \\
(0.004)\end{array}$ & $\begin{array}{c}0.400^{* * *} \\
(0.004)\end{array}$ & $\begin{array}{c}0.567^{* * *} \\
(0.005)\end{array}$ \\
\hline All three x Post & $\begin{array}{c}-0.033^{* * *} \\
(0.002)\end{array}$ & $\begin{array}{c}-0.006^{* * *} \\
(0.001)\end{array}$ & $\begin{array}{c}-0.036^{* * *} \\
(0.003)\end{array}$ & $\begin{array}{c}0.369^{* * *} \\
(0.003)\end{array}$ & $\begin{array}{c}-0.055^{* * *} \\
(0.004)\end{array}$ & $\begin{array}{c}0.568^{* * *} \\
(0.008)\end{array}$ & $\begin{array}{c}-0.059^{* * *} \\
(0.005)\end{array}$ & $\begin{array}{c}0.414^{* * *} \\
(0.006)\end{array}$ & $\begin{array}{c}0.544^{* * *} \\
(0.007)\end{array}$ \\
\hline Observations & 134,288 & 134,288 & 134,288 & 134,288 & 134,288 & 134,288 & 134,288 & 134,288 & 134,288 \\
\hline $\mathrm{R}^{2}$ & 0.102 & 0.098 & 0.101 & 0.210 & 0.177 & 0.616 & 0.395 & 0.552 & 0.627 \\
\hline
\end{tabular}

Notes: This table shows the coefficients of several dummies for each possible combination of the TWI training. For example, $J-I$ is equal to one for firms that received only the J-I module, while $J-I$ and $J$ - $R$ is equal to one for firms that received only the J-I and J-R modules. All the dependent variables are logged with the exception of two dummy variables that measure whether firms reported expenditures for on-the-job training (column 6; mean=0.18) or for marketing activities (column 9; mean=0.17). The regressions also include the training variables in isolation, as well as fixed effects for countysector-period combinations, the application window, and the number of days between the opening of the window and the firm application. Standard errors are clustered at the level of subdistricts and application windows. ${ }^{* * *} \mathrm{p}<0.01,{ }^{* *} \mathrm{p}<0.05,{ }^{*} \mathrm{p}<0.1$. 
Table A12: Complementarity Effects, Alternative Specification 2

\begin{tabular}{|c|c|c|c|c|c|c|c|c|c|}
\hline & $\begin{array}{l}\text { Log } \\
\text { repairs } \\
(1) \\
\end{array}$ & $\begin{array}{c}\log \\
\text { maintenance } \\
(2) \\
\end{array}$ & $\begin{array}{c}\log \\
\text { injuries } \\
(3) \\
\end{array}$ & $\begin{array}{c}\text { Log } \\
\text { bonus } \\
(4) \\
\end{array}$ & $\begin{array}{c}\log \\
\text { strikes } \\
(5) \\
\end{array}$ & $\begin{array}{c}\text { Prob } \\
\text { training } \\
(6)\end{array}$ & $\begin{array}{c}\log \\
\text { inventory } \\
(7)\end{array}$ & $\begin{array}{c}\text { Log } \\
\text { product lines } \\
(8)\end{array}$ & $\begin{array}{c}\text { Prob } \\
\text { marketing } \\
(9)\end{array}$ \\
\hline J-I x Post & $\begin{array}{c}-0.034^{* * *} \\
(0.003)\end{array}$ & $\begin{array}{c}0.012^{* * *} \\
(0.002)\end{array}$ & $\begin{array}{c}-0.034^{* * *} \\
(0.004)\end{array}$ & $\begin{array}{l}-0.002 \\
(0.003)\end{array}$ & $\begin{array}{c}0.031^{* * *} \\
(0.003)\end{array}$ & $\begin{array}{c}-0.033^{* * *} \\
(0.004)\end{array}$ & $\begin{array}{c}0.003 \\
(0.004)\end{array}$ & $\begin{array}{c}0.010^{* * *} \\
(0.004)\end{array}$ & $\begin{array}{c}-0.010^{* *} \\
(0.004)\end{array}$ \\
\hline J-R x Post & $\begin{array}{c}0.003 \\
(0.003)\end{array}$ & $\begin{array}{l}-0.002 \\
(0.002)\end{array}$ & $\begin{array}{c}0.000 \\
(0.004)\end{array}$ & $\begin{array}{c}0.389^{* * *} \\
(0.003)\end{array}$ & $\begin{array}{c}-0.172^{* * *} \\
(0.004)\end{array}$ & $\begin{array}{c}0.545^{* * *} \\
(0.007)\end{array}$ & $\begin{array}{c}0.006 \\
(0.004)\end{array}$ & $\begin{array}{c}0.012^{* * *} \\
(0.004)\end{array}$ & $\begin{array}{c}-0.011^{* * *} \\
(0.004)\end{array}$ \\
\hline J-M x Post & $\begin{array}{l}-0.002 \\
(0.003)\end{array}$ & $\begin{array}{l}-0.003 \\
(0.002)\end{array}$ & $\begin{array}{c}0.004 \\
(0.004)\end{array}$ & $\begin{array}{c}0.001 \\
(0.002)\end{array}$ & $\begin{array}{c}0.029^{* * *} \\
(0.002)\end{array}$ & $\begin{array}{c}-0.033^{* * *} \\
(0.004)\end{array}$ & $\begin{array}{c}-0.060^{* * * *} \\
(0.005)\end{array}$ & $\begin{array}{c}0.342^{* * *} \\
(0.005)\end{array}$ & $\begin{array}{c}0.564^{* * *} \\
(0.007)\end{array}$ \\
\hline J-I x J-R x Post & $\begin{array}{l}-0.000 \\
(0.003)\end{array}$ & $\begin{array}{c}-0.015^{* * *} \\
(0.002)\end{array}$ & $\begin{array}{c}0.005 \\
(0.005)\end{array}$ & $\begin{array}{l}-0.006^{*} \\
(0.003)\end{array}$ & $\begin{array}{c}-0.047^{* * *} \\
(0.004)\end{array}$ & $\begin{array}{c}0.025 * * * \\
(0.007)\end{array}$ & $\begin{array}{l}-0.004 \\
(0.005)\end{array}$ & $\begin{array}{c}-0.026^{* * * *} \\
(0.006)\end{array}$ & $\begin{array}{l}-0.007 \\
(0.007)\end{array}$ \\
\hline $\mathrm{J}-\mathrm{R} \times \mathrm{J}-\mathrm{M} \times$ Post & $\begin{array}{l}-0.002 \\
(0.003)\end{array}$ & $\begin{array}{l}0.003^{*} \\
(0.002)\end{array}$ & $\begin{array}{l}-0.006 \\
(0.005)\end{array}$ & $\begin{array}{c}-0.014^{* * *} \\
(0.003)\end{array}$ & $\begin{array}{c}-0.046^{* * *} \\
(0.004)\end{array}$ & $\begin{array}{c}0.039 * * * \\
(0.007)\end{array}$ & $\begin{array}{l}-0.001 \\
(0.005)\end{array}$ & $\begin{array}{c}0.036^{* * *} \\
(0.005)\end{array}$ & $\begin{array}{c}0.007 \\
(0.006)\end{array}$ \\
\hline J-M x J-I x Post & $\begin{array}{c}0.003 \\
(0.003)\end{array}$ & $\begin{array}{l}-0.002 \\
(0.002)\end{array}$ & $\begin{array}{l}-0.003 \\
(0.005)\end{array}$ & $\begin{array}{l}0.001 \\
(0.003)\end{array}$ & $\begin{array}{c}0.162^{* * *} \\
(0.004)\end{array}$ & $\begin{array}{c}0.028^{* * *} \\
(0.007)\end{array}$ & $\begin{array}{l}-0.006 \\
(0.006)\end{array}$ & $\begin{array}{c}0.046^{* * *} \\
(0.006)\end{array}$ & $\begin{array}{c}0.010 \\
(0.007)\end{array}$ \\
\hline Observations & 134,288 & 134,288 & 134,288 & 134,288 & 134,288 & 134,288 & 134,288 & 134,288 & 134,288 \\
\hline $\mathrm{R}^{2}$ & 0.101 & 0.098 & 0.101 & 0.210 & 0.177 & 0.615 & 0.395 & 0.552 & 0.627 \\
\hline
\end{tabular}

Notes: This table shows the coefficients of several dummies for each type of TWI training, as well as their interaction. $\mathrm{J}-\mathrm{x}$ is one for all firms that received the $\mathrm{J}$-x training. For example, J-I is equal to one for firms that received only the J-I module, as well as for firms that received the J-I and J$\mathrm{R}$ modules. All the dependent variables are logged with the exception of two dummy variables that measure whether firms reported expenditures for on-the-job training (column 6; mean=0.18) or for marketing activities (column 9; mean=0.17). The regressions also include the training variables in isolation, as well as fixed effects for county-sector-period combinations, the application window, and the number of days between the opening of the window and the firm application. The sample includes all applicant firms. Standard errors are clustered at the level of subdistricts and application windows. $* * * \mathrm{p}<0.01, * * \mathrm{p}<0.05,{ }^{*} \mathrm{p}<0.1$. 
Table A13: Effects on Upstream and Downstream Firms, Heterogeneity Analysis

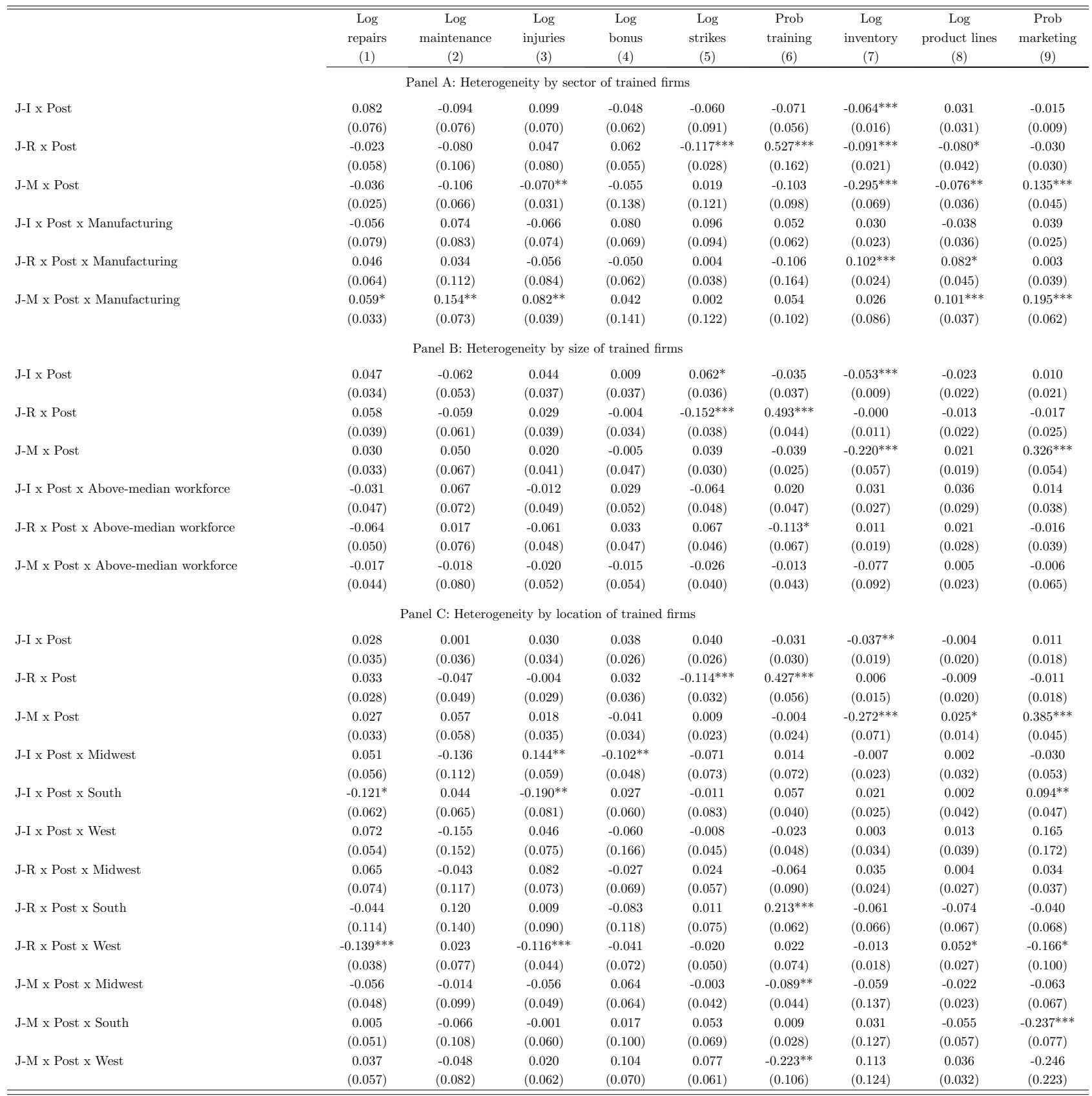

Notes: The sample used for this table includes 1,816 upstream and downstream firms linked to 1,572 firms that applied to the TWI program. Panel A tests whether there are heterogeneous effects based on the sector of the trained firms. Panel B tests whether there are heterogeneous effects based on the workforce size of the trained firms in period -1 . Panel $\mathrm{C}$ tests whether there are heterogeneous effects based on the location (U.S. Census Bureau region) of the trained firms. These regressions also include the interaction between the training variable and the "heterogeneity dummies," the interaction between the period fixed effects and the "heterogeneity dummies," the training variables by themselves, the "heterogeneity dummies" by themselves, as well as fixed effects for county-sectorperiod combinations, the application window of the applicant firm, and the number of days between the opening of the window and the firm application. Standard errors are clustered at the level of subdistricts and application windows. ${ }^{* * *} \mathrm{p}<0.01,{ }^{*} * \mathrm{p}<0.05,{ }^{*} \mathrm{p}<0.1$. 
Table A14: Selection of Firms Entering the Applicants' Supply Chain

\begin{tabular}{|c|c|c|c|c|c|c|c|}
\hline & $\begin{array}{c}\text { Log } \\
\text { sales } \\
(1) \\
\end{array}$ & $\begin{array}{l}\text { TFP } \\
(2) \\
\end{array}$ & $\begin{array}{c}\text { Log } \\
\text { ROA } \\
(3) \\
\end{array}$ & $\begin{array}{c}\text { Log } \\
\text { plants } \\
(4) \\
\end{array}$ & $\begin{array}{c}\log \\
\text { employees } \\
(5)\end{array}$ & $\begin{array}{c}\log \\
\text { managers } \\
(6)\end{array}$ & $\begin{array}{c}\log \\
\text { subsidiaries } \\
(7)\end{array}$ \\
\hline TWI & $\begin{array}{c}0.017^{* * *} \\
(0.001)\end{array}$ & $\begin{array}{c}0.193^{* * *} \\
(0.006)\end{array}$ & $\begin{array}{l}-0.018 \\
(0.033)\end{array}$ & $\begin{array}{c}0.099^{* * *} \\
(0.012)\end{array}$ & $\begin{array}{c}0.099^{* * *} \\
(0.009)\end{array}$ & $\begin{array}{c}0.111^{* * *} \\
(0.027)\end{array}$ & $\begin{array}{c}0.107^{* * *} \\
(0.011)\end{array}$ \\
\hline Observations & 686 & 686 & 686 & 686 & 686 & 686 & 686 \\
\hline $\mathrm{R}^{2}$ & 0.533 & 0.738 & 0.120 & 0.266 & 0.337 & 0.148 & 0.287 \\
\hline
\end{tabular}

Notes. This table shows cross-sectional correlations between the characteristics of upstream and downstream firms joining the supply chain of TWI applicants after the TWI program and the training variable. The only period considered is -1 , the year before the entry in the supply chain of applicant firms. The sample includes 715 upstream and downstream firms that entered the supply chain of 660 TWI applicants only after the TWI program. The regressions also include fixed effects for district-sector combinations, the application window, and the number of days between the opening of the window and the firm application. Standard errors are clustered at the level of subdistricts and application windows. $* * * \mathrm{p}<0.01, * * \mathrm{p}<0.05, * \mathrm{p}<0.1$. 
Table A15: Summary Statistics for 11,536 Nonapplicant War Contractors

\begin{tabular}{|c|c|c|c|c|c|c|}
\hline & \multicolumn{4}{|c|}{ Nonapplicant firms } & \multirow{3}{*}{$\begin{array}{l}\text { Difference with } \\
\text { applicants } \\
(5)\end{array}$} & \multirow{3}{*}{$\begin{array}{c}\text { Difference with } \\
\text { matched applicants } \\
(6)\end{array}$} \\
\hline & Mean & St. Dev. & Min & Max & & \\
\hline & $(1)$ & $(2)$ & $(3)$ & $(4)$ & & \\
\hline \multicolumn{7}{|c|}{$\underline{\text { Panel A: Data from annual financial statements in } 1939}$} \\
\hline Plants & 2.61 & 0.73 & 1 & 4 & -3.47 & -0.60 \\
\hline Employees & 618.26 & 98.90 & 265 & 970 & -420.06 & -63.98 \\
\hline Foundation year & 1923 & 2.03 & 1916 & 1930 & -8.01 & -8.09 \\
\hline Agriculture & 0.03 & 0.17 & 0 & 1 & 0.01 & -0.01 \\
\hline Manufacturing & 0.86 & 0.35 & 0 & 1 & -0.01 & -0.01 \\
\hline Transportation & 0.09 & 0.29 & 0 & 1 & 0.01 & 0.01 \\
\hline Services & 0.02 & 0.15 & 0 & 1 & 0.01 & 0.01 \\
\hline Sales & 90.00 & 0.01 & 89.95 & 90.05 & -101.78 & -52.94 \\
\hline Current assets & 1.18 & 0.29 & 0.66 & 1.74 & -17.22 & -12.39 \\
\hline Total assets & 3.64 & 0.35 & 2.95 & 4.39 & -60.81 & -43.85 \\
\hline TFP & 4.09 & 0.37 & 3.30 & 4.74 & 0.22 & 0.05 \\
\hline $\mathrm{ROA}$ & 0.07 & 0.01 & 0.05 & 0.09 & 0.04 & 0.04 \\
\hline Inventory & 0.54 & 0.07 & 0.28 & 0.84 & -14.83 & -10.75 \\
\hline Injuries & 0.88 & 0.24 & 0.44 & 1.62 & -9.52 & -6.88 \\
\hline Repairs & 1.35 & 0.26 & 0.90 & 1.80 & -14.02 & -10.09 \\
\hline Bonus payments & 2.25 & 0.78 & 0.90 & 3.60 & -6.02 & -3.95 \\
\hline \multicolumn{7}{|c|}{ Panel B: Workforce data from replacement lists in 1941} \\
\hline Share African-Americans & 0.05 & 0.01 & 0.04 & 0.07 & -0.01 & -0.01 \\
\hline Share women & 0.04 & 0.01 & 0.03 & 0.05 & -0.01 & -0.01 \\
\hline Years of education & 7 & 1.05 & 3 & 11 & -1.51 & -1.53 \\
\hline Age of workforce & 23.02 & 5.02 & 4 & 42 & -5.96 & -5.90 \\
\hline \multicolumn{7}{|c|}{$\underline{\text { Panel C: WWII-related data from replacement lists and war contracts }}$} \\
\hline Share drafted employees (1942-1945) & 0.20 & 0.09 & 0 & 0.35 & -0.03 & 0.01 \\
\hline Switched 3-digit SIC (1940-1945) & 1 & 0 & 1 & 1 & 0 & 0 \\
\hline Switched 2-digit SIC (1940-1945) & 0.54 & 0.50 & 0 & 1 & -0.02 & -0.05 \\
\hline Switched 1-digit SIC (1940-1945) & 0.35 & 0.48 & 0 & 1 & -0.02 & -0.04 \\
\hline Number of contracts (1940-1945) & 1.90 & 7.30 & 0 & 123 & 1.22 & 1.21 \\
\hline Value of contracts (1940-1945) & 18.26 & 250.76 & 0 & 38,771 & -6.85 & -9.59 \\
\hline
\end{tabular}

Notes. Summary statistics for 11,536 firms that applied to the TWI program and for which we found financial data (out of 13,818 total nonapplicants). Column 5 shows the average difference with respect to all applicants. Column 6 shows the average difference with respect to 2,223 applicants that were matched to nonapplicants. The matching was based on propensity scores, using a nearest-neighbor algorithm without replacement. The variables used for the matching were the number of plants and employees in 1939, TFP in 1939, distance from the nearest port and railroad station, sector, and fixed effects for the 22 TWI districts. A description of the variables is available under Table 1 and in Appendix B. 
Table A16: Spillover of Practices to Nonapplicant Firms

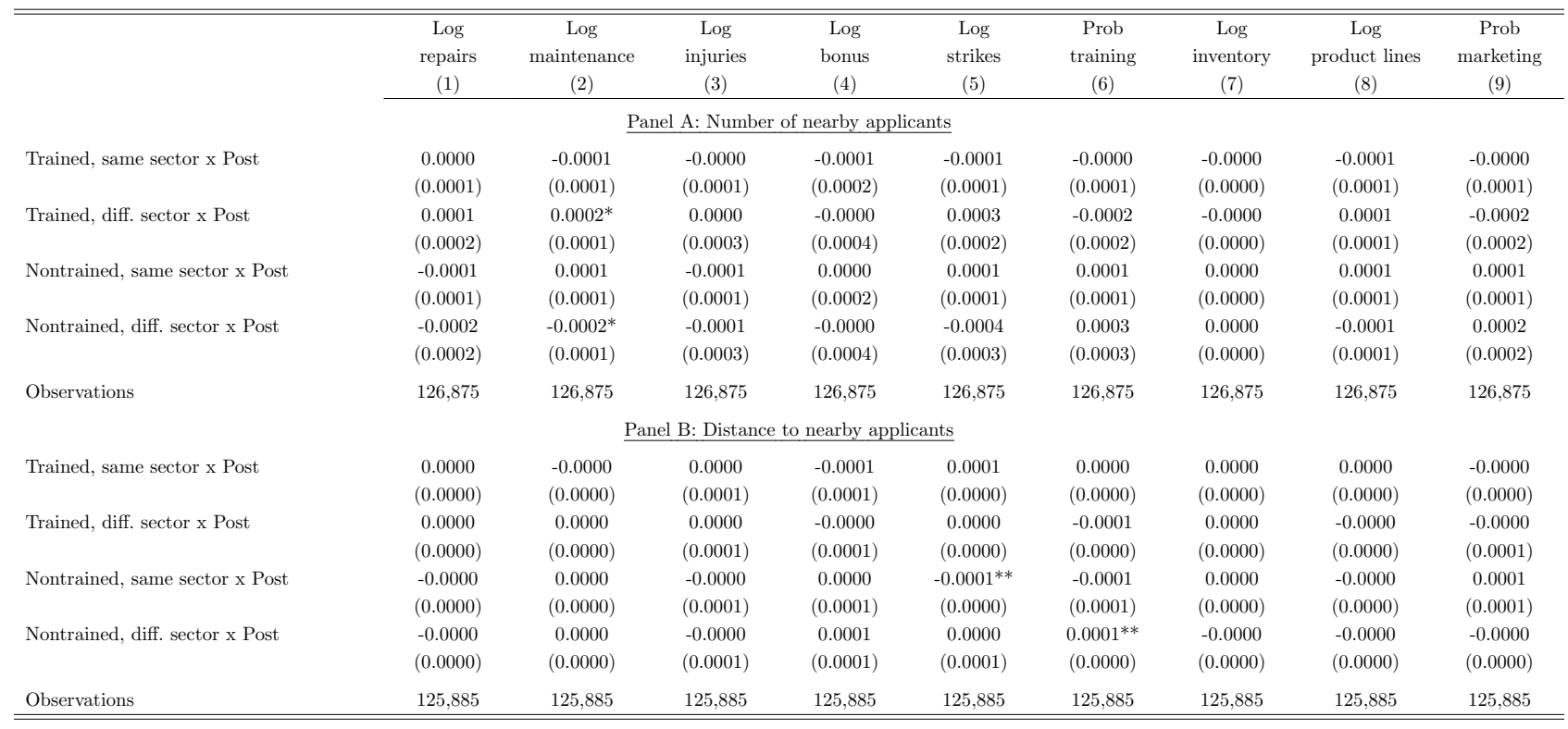

Notes: The sample used for these graphs includes 11,536 war contractors that did not apply to the TWI program and for which we found financial statements (out of 13,818 total nonapplicants). In panel A, the coefficients shown are the interactions between the $\log$ number of applicants in the area and a post-TWI dummy. The number of applicants is divided between trained and nontrained firms and between firms in the same or different sector (agriculture, manufacturing, transportation, or services). Panel B uses the $\log$ of the average distance from applicant firms, instead of the log number of firms. In order to compute the number of nearby applicant firms and their average distance to nonapplicant firms, we divided the 364 subdistricts into 52 groups of 7 adjacent subdistricts. Period 0 coincides with the modal treatment year within each of the 52 groups of subdistricts. All regressions also include firm fixed effects. The standard errors are clustered at the subdistrict level. ${ }^{* * *} \mathrm{p}<0.01,{ }^{* *} \mathrm{p}<0.05,{ }^{*} \mathrm{p}<0.1$.

Table A17: Adoption of Practices and Managers Leaving

\begin{tabular}{|c|c|c|c|c|c|c|c|c|c|}
\hline & $\begin{array}{l}\log \\
\text { repairs } \\
(1) \\
\end{array}$ & $\begin{array}{c}\log \\
\text { maintenance } \\
(2)\end{array}$ & $\begin{array}{c}\log \\
\text { injuries } \\
(3)\end{array}$ & $\begin{array}{c}\log \\
\text { bonus } \\
(4)\end{array}$ & $\begin{array}{c}\log \\
\text { strikes } \\
(5)\end{array}$ & $\begin{array}{c}\text { Prob } \\
\text { training } \\
(6)\end{array}$ & $\begin{array}{c}\log \\
\text { inventory } \\
(7)\end{array}$ & $\begin{array}{c}\text { Log } \\
\text { product lines } \\
(8)\end{array}$ & $\begin{array}{c}\text { Prob } \\
\text { marketing } \\
(9)\end{array}$ \\
\hline J-I x Post & $\begin{array}{c}-0.040^{* * *} \\
(0.004)\end{array}$ & $\begin{array}{c}0.013^{* * *} \\
(0.003)\end{array}$ & $\begin{array}{c}-0.040^{* * *} \\
(0.007)\end{array}$ & $\begin{array}{c}0.001 \\
(0.005)\end{array}$ & $\begin{array}{c}0.010^{* * *} \\
(0.002)\end{array}$ & $\begin{array}{c}-0.037^{* * *} \\
(0.005)\end{array}$ & $\begin{array}{c}0.012^{* *} \\
(0.006)\end{array}$ & $\begin{array}{c}0.004 \\
(0.006)\end{array}$ & $\begin{array}{c}-0.027^{* * *} \\
(0.004)\end{array}$ \\
\hline J-R $x$ Post & $\begin{array}{c}0.002 \\
(0.005)\end{array}$ & $\begin{array}{l}-0.000 \\
(0.003)\end{array}$ & $\begin{array}{c}0.002 \\
(0.006)\end{array}$ & $\begin{array}{c}0.385^{* * *} \\
(0.005)\end{array}$ & $\begin{array}{c}-0.197^{* * *} \\
(0.005)\end{array}$ & $\begin{array}{c}0.547^{* * *} \\
(0.013)\end{array}$ & $\begin{array}{l}0.015^{* *} \\
(0.006)\end{array}$ & $\begin{array}{c}0.006 \\
(0.006)\end{array}$ & $\begin{array}{c}-0.021^{* * *} \\
(0.003)\end{array}$ \\
\hline J-M x Post & $\begin{array}{l}-0.002 \\
(0.004)\end{array}$ & $\begin{array}{c}0.001 \\
(0.002)\end{array}$ & $\begin{array}{c}0.003 \\
(0.006)\end{array}$ & $\begin{array}{c}0.000 \\
(0.004)\end{array}$ & $\begin{array}{c}0.007^{* * *} \\
(0.002)\end{array}$ & $\begin{array}{c}-0.036^{* * *} \\
(0.004)\end{array}$ & $\begin{array}{c}-0.056^{* * *} \\
(0.008)\end{array}$ & $\begin{array}{c}0.341^{* * *} \\
(0.008)\end{array}$ & $\begin{array}{c}0.559^{* * *} \\
(0.011)\end{array}$ \\
\hline J-I x Post x Median leaving & $\begin{array}{c}0.008 \\
(0.007)\end{array}$ & $\begin{array}{c}0.001 \\
(0.004)\end{array}$ & $\begin{array}{c}0.007 \\
(0.010)\end{array}$ & $\begin{array}{l}-0.006 \\
(0.007)\end{array}$ & $\begin{array}{l}-0.001 \\
(0.003)\end{array}$ & $\begin{array}{c}0.000 \\
(0.007)\end{array}$ & $\begin{array}{l}-0.005 \\
(0.008)\end{array}$ & $\begin{array}{l}-0.007 \\
(0.008)\end{array}$ & $\begin{array}{l}-0.002 \\
(0.006)\end{array}$ \\
\hline J-R x Post x Median leaving & $\begin{array}{l}-0.006 \\
(0.007)\end{array}$ & $\begin{array}{l}-0.002 \\
(0.004)\end{array}$ & $\begin{array}{l}-0.010 \\
(0.009)\end{array}$ & $\begin{array}{c}0.009 \\
(0.007)\end{array}$ & $\begin{array}{c}0.005 \\
(0.009)\end{array}$ & $\begin{array}{l}-0.016 \\
(0.018)\end{array}$ & $\begin{array}{l}-0.005 \\
(0.008)\end{array}$ & $\begin{array}{l}-0.010 \\
(0.008)\end{array}$ & $\begin{array}{l}-0.006 \\
(0.005)\end{array}$ \\
\hline J-M x Post x Median leaving & $\begin{array}{l}-0.005 \\
(0.006)\end{array}$ & $\begin{array}{l}-0.005 \\
(0.004)\end{array}$ & $\begin{array}{l}-0.005 \\
(0.010)\end{array}$ & $\begin{array}{c}0.003 \\
(0.006)\end{array}$ & $\begin{array}{l}-0.001 \\
(0.003)\end{array}$ & $\begin{array}{c}0.003 \\
(0.006)\end{array}$ & $\begin{array}{l}-0.000 \\
(0.011)\end{array}$ & $\begin{array}{l}-0.018 \\
(0.011)\end{array}$ & $\begin{array}{l}-0.019 \\
(0.018)\end{array}$ \\
\hline Observations & 67,472 & 67,472 & 67,472 & 67,472 & 67,472 & 67,472 & 67,472 & 67,472 & 67,472 \\
\hline $\mathrm{R}^{2}$ & 0.142 & 0.132 & 0.141 & 0.168 & 0.160 & 0.436 & 0.406 & 0.342 & 0.496 \\
\hline
\end{tabular}

Notes: Median leaving is equal to 1 for firms with an above-median (52 percent) share of top executives leaving the company between the end of training and 1955. To compute this variable, we compare the list of top executives in 1955 (or last year in which a firm is observed) to the list of top executives in period 0 , the year of the TWI training. These regressions also include the interaction between the training variable and Median leaving, the interaction between the period fixed effects and Median leaving, the training variables by themselves, Median leaving by itself, as well as fixed effects for county-sector-period combinations, the application window of the applicant firm, and the number of days between the opening of the window and the firm application. Standard errors are clustered at the level of subdistricts and application windows. ${ }^{* * *} \mathrm{p}<0.01,{ }^{* *} \mathrm{p}<0.05,{ }^{*} \mathrm{p}<0.1$. 
Table A18: Relationship with the Government

\begin{tabular}{|c|c|c|c|c|c|}
\hline & $\begin{array}{c}\text { Has } \\
\text { contracts } \\
(1)\end{array}$ & $\begin{array}{l}\text { Value } \\
\text { contracts } \\
(2)\end{array}$ & $\begin{array}{l}\text { Number } \\
\text { contracts } \\
(3)\end{array}$ & $\begin{array}{c}\text { Above-median } \\
\text { value } \\
(4)\end{array}$ & $\begin{array}{c}\text { Top-tertile } \\
\text { value } \\
(5)\end{array}$ \\
\hline & \multicolumn{5}{|c|}{ Panel A: War contract data between -3 and +2} \\
\hline TWI x Post & $\begin{array}{c}0.015 \\
(0.018)\end{array}$ & $\begin{array}{c}0.346 \\
(0.292)\end{array}$ & $\begin{array}{c}0.027 \\
(0.021)\end{array}$ & $\begin{array}{c}0.022 \\
(0.017)\end{array}$ & $\begin{array}{c}0.007 \\
(0.016)\end{array}$ \\
\hline $\begin{array}{l}\text { Observations } \\
\mathrm{R}^{2}\end{array}$ & $\begin{array}{c}24,805 \\
0.176\end{array}$ & $\begin{array}{c}20,741 \\
0.170\end{array}$ & $\begin{array}{c}20,741 \\
0.167\end{array}$ & $\begin{array}{c}20,741 \\
0.166\end{array}$ & $\begin{array}{c}20,741 \\
0.151\end{array}$ \\
\hline & \multicolumn{5}{|c|}{ Panel B: War contract data between -4 and +2} \\
\hline TWI x Post & $\begin{array}{l}0.013 \\
(0.017)\end{array}$ & $\begin{array}{c}0.283 \\
(0.288)\end{array}$ & $\begin{array}{c}0.023 \\
(0.021)\end{array}$ & $\begin{array}{c}0.017 \\
(0.017)\end{array}$ & $\begin{array}{c}0.005 \\
(0.016)\end{array}$ \\
\hline Observations & 27,186 & 23,122 & 23,122 & 23,122 & 23,122 \\
\hline $\mathrm{R}^{2}$ & 0.185 & 0.191 & 0.186 & 0.186 & 0.158 \\
\hline & \multicolumn{5}{|c|}{ Panel C: War contract data between -5 and +2} \\
\hline TWI x Post & $\begin{array}{c}0.012 \\
(0.017)\end{array}$ & $\begin{array}{c}0.271 \\
(0.285)\end{array}$ & $\begin{array}{c}0.022 \\
(0.020)\end{array}$ & $\begin{array}{c}0.016 \\
(0.017)\end{array}$ & $\begin{array}{c}0.005 \\
(0.016)\end{array}$ \\
\hline Observations & 28,353 & 24,289 & 24,289 & 24,289 & 24,289 \\
\hline $\mathrm{R}^{2}$ & 0.193 & 0.203 & 0.197 & 0.197 & 0.164 \\
\hline
\end{tabular}

Panel D: Postwar and cross-sectional variables

\begin{tabular}{|c|c|c|c|c|c|}
\hline & $\begin{array}{c}\text { Postwar } \\
\text { refunds } \\
(1)\end{array}$ & $\begin{array}{c}\text { Supply } \\
\text { combat } \\
(2)\end{array}$ & $\begin{array}{c}\text { Supply } \\
\text { other } \\
(3)\end{array}$ & $\begin{array}{c}\text { Projects } \\
\text { industrial } \\
(4)\end{array}$ & $\begin{array}{c}\text { Projects } \\
\text { military } \\
(5)\end{array}$ \\
\hline TWI & $\begin{array}{c}-0.000 \\
(0.000)\end{array}$ & $\begin{array}{c}0.117 \\
(0.171)\end{array}$ & $\begin{array}{c}0.057 \\
(0.073)\end{array}$ & $\begin{array}{c}0.055 \\
(0.198)\end{array}$ & $\begin{array}{c}-0.246 \\
(0.231)\end{array}$ \\
\hline Observations & 20,388 & 4,601 & 4,601 & 4,601 & 4,601 \\
\hline $\mathrm{R}^{2}$ & 0.131 & 0.607 & 0.687 & 0.583 & 0.637 \\
\hline
\end{tabular}

Notes. Has contracts is a dummy equal to one for firms with at least one new contract in a given year. Number contracts and Value contracts are the inverse hyperbolic sine function (preferable over logs due to zeros) of the number and value of war contracts granted to each firm per year. Above-median value is a dummy equal to one for firms above the median of values of war contracts in each year. Top-tertile value is a dummy equal to one for firms in the top tertile of values of war contracts in each year. These variables come from war contracts data and are therefore available only between 1940 and 1945. The number of firms with nonmissing values is 3,974 in period $-5,7,332$ in period $-4,10,607$ in period $-3,11,545$ in period $-2,11,567$ in period $-1,11,575$ in period 0 , 7,601 in period 1, and 4,243 in period 2. Postwar Refunds is the log of subsidies given by the government to war contractors to switch from military to civilian production after World War II. They are available only from 1946 to 1951 . Therefore, we need to estimate a single-difference specification, instead of the usual difference-in-differences event study. All regressions also include fixed effects for county-sector-period combinations, the application window, and the number of days between the opening of the window and the firm application. In Panel D, columns 2 to 5 have dependent variables that measure the total value of war-related government spending between 1940 and 1945 in the county of each applicant firm. Supply combat is the inverse hyperbolic sine function of the total value of supply contracts for combat equipment, while Supply combat is the inverse hyperbolic sine function of the total value of supply contracts for noncombat equipment. Projects industrial is the inverse hyperbolic sine function of the total value of projects for the construction of industrial facilities, while Projects military is the inverse hyperbolic sine function of the total value of projects for the construction of military facilities. These regressions also include fixed effects for subdistrict-sector combinations, the application window, and the number of days between the opening of the window and the firm application. The data come from https://www.icpsr.umich.edu/web/ICPSR/studies/02896/variables?q=war. Standard errors are clustered at the level of subdistricts and application windows. ${ }^{* * *} \mathrm{p}<0.01,{ }^{* *} \mathrm{p}<0.05,{ }^{*} \mathrm{p}<0.1$. 


\section{B Data Collection and Variable Construction}

\section{Data Collection}

The data collection targeted firms eligible to apply to the TWI program. In order to apply, firms had to be located in the United States and needed to win at least one war contract between June 1940 and August 1945. To identify the eligible companies, we used the tabulation of war supply contracts published by the Civilian Production Administration in 1946, which Dmitri Koustas digitized and kindly shared with us. This dataset includes information on all contracts for war supplies worth at least $\$ 50,000$ and awarded between June, 1940 and September, 1945. The minimum threshold at $\$ 50,000$ in 1945 USD or $\$ 710,000$ in 2020 USD (https://www.measuringworth.com/calculators/uscompare/) is unlikely to be binding for the type of war contracts received by applicant firms. If we consider the distribution of the average value of war contracts received by the firms in our sample, the median is equal to $\$ 4.2$ million (2020 USD), while the mean is equal to $\$ 56.5$ million (2020 USD). Out of 25,627 companies with at least one contract in these five years, we excluded 234 firms located outside the United States, obtaining a list of 25,393 companies eligible to participate in the TWI program. ${ }^{32}$ We then constructed a panel dataset gathering four different types of data.

TWI Monthly Program Development Reports (1940-1945). We retrieved and digitized the list of applicant firms from the monthly program development reports compiled by the TWI administration between August 22, 1940 and September 19, 1945. These reports are stored at the National Archives and Record Administration (Record Group 211, "Records of the War Manpower Commission [WMC]," 1936-1947, College Park, MD). Out of 25,393 eligible firms, we were able to find applications from 11,575 companies. ${ }^{33}$ For each application, the monthly records indicate the application date, the district and subdistrict in which the applicant firm was located, whether it eventually received the TWI training, in which of the J-modules it was trained, and the year in which each module was delivered. Moreover, we also retrieved and digitized the list of the instructors trained by the TWI service who delivered the J-modules to participant firms. For each instructor, we know their full name, whether they were employed by the government before the TWI program, whether they were hired full time or part-time, in which specific J-module they were trained, and to which subdistrict they were assigned. In total, the TWI instructors were 48,424.

Plant-level Surveys (1940-1945). In order to test the effectiveness of the program, the TWI administration conducted plant-level surveys in the firms that received the TWI training. Specifically, the surveys - stored at the National Archives and Record Administration (Record Group 211, "Records of the War Manpower Commission [WMC]," 1936-1947, College Park, MD) -indicate whether a plant was performing each of eleven managerial practices linked to the teachings of the TWI program. The plan managers were interviewed before the start of each J-module training, three months after the TWI training, and then each year thereafter until 1945. Overall, this dataset contain information about 38,241 surveyed establishments. We digitized these data and then we matched them to the list of applicant firms using name, municipality and state in which the firm's headquarters were located.

Replacement Schedules (1942-1945). After the Executive Order 9279 of December 5, 1942, firms in which at least one worker was drafted had to submit a replacement schedule to their regional Bureau of Manpower Utilization. In the schedules - stored at National Archives and Record Administration (Record Group 211, "Records of the War Manpower Commission [WMC]," 1936-1947, College Park, MD)—, firms provided a description of their products, as well as a list of firms they were selling to and buying from. Moreover, they reported the composition of their labor force, specifically indicating the share of African-American workers

${ }^{32}$ These companies, which were granted 772 contracts in total, were located in: Arabia (1), Argentina (22), Australia (4), Belgium (1), Bermuda (5), Brazil (5), British West Indies (6), Canada (123), Chile (3), China (2), Congo (1), Cuba (6), Denmark (1), Dominican Republic (2), Ecuador (1), Finland (1), India (5), Iran (1), Malaysia (1), Mexico, (9) Nicaragua (3), Panama (6), Peru (2), Philippines (3), Switzerland (8), Thailand (1), UK (7), and Venezuela (4).

${ }^{33}$ As noted in Brunet (2019), firms may appear in contract listings with numerous locations, which in some cases makes unclear whether there are multiple firms with the same name or one firm with multiple facilities. We solve this ambiguity by checking how firms were listed in the TWI reports. Specifically, if we found two firms with the same name but in different locations listed as two separate entities receiving the TWI service, we consider them as two separate firms. 
and women, as well as the average years of education and age of all their employees. Finally, they had to list the names of drafted employees, their job titles, their relative ranking within the firm hierarchy, their age, their current Selective Service classification, their family status, their local board identity, and their draft order number, as well as the time needed to replace them with new workers (hence, then name "replacement schedules"). Through these replacement schedules, employers could also ask for exemptions from the draft for some categories of their workers. According to the Selective Training and Service Act of 1940, men between the ages of 18 and 45 were classified into four categories: (1) men available for training and service; (2) men deferred because of occupational status; (3) men deferred because of dependents; (4) men deferred by law or who were unfit for service. The Selective Service System, operating at a decentralized level through its 6,443 local boards, processed the exemption requests, mostly based on the information given by the draftees at the time of registering. Managers were usually deferred "in support of national health, safety, or interest" (category II-A). While the replacement schedules started being submitted in 1942, the first schedule contained data on both 1941 and 1942. Using firm name, municipality, and state, we searched for firms eligible for the TWI program in the replacement lists. Given the large size of war contractors, all of them had at least one worker drafted between 1940 and 1945. Therefore, we were able to match all applicant firms to the newly digitized dataset of replacement schedules.

Firm Performance (1935-1955). We retrieved information on the economic outcomes of U.S. war contractors from their balance sheets and income statements. To do so, we relied on the "Historical Annual Reports" collection of the Mergent Archives, which is composed of more than one million corporate financial statements collected directly from company archives, universities, libraries, and private collections. ${ }^{34}$ In Summer 2016, we accessed the data through the subscription of the University of California-Irvine. Specifically, we searched the UCI library's search engine for the name, municipality and state of each U.S. war contractor, collecting any document published between 1935 and 1955. For each firm and year found, we were able to download the annual financial reports a single pdf page at time after inserting a verification code for each downloaded page. If we did not find a firm before its first U.S. war contract, we used the foundation date to determine if this was due to a missing statement or if the firm had not been founded yet. If we stopped finding a firm after its last U.S. war contract, we assumed that the firm had exited the market.. We were able to find at least one match for all the 11,575 applicants firms and for 11,536 out of 13,857 (83 percent) nonapplicants. We believe that the lower matching rate among nonapplicants is likely due to the smaller size. Even though there is not a formal threshold on firm size to be included in the Mergent Archives, in practice, publicly traded firms, firms issuing bonds, and larger firms are more likely to be included because it is relatively easier to find their balance sheets.

\section{Variables Construction and Definition}

In Table B1, we provide a list of all the variables used in the paper with their definitions and data sources. When needed, we also provide additional details on the variable construction. All the monetary values have been reevaluated to 2020 USD using https://www.measuringworth.com/calculators/uscompare/.

\section{Definition of Sector and Identification of Firms in the Supply Chain}

The annual financial reports do not include information on a firm's sector. To retrieve this piece of information, we rely on the replacement schedules. In fact, firms had to report the products not covered by a war contract for the year 1941, the year before the draft started. We therefore classify these products using the Standard Industrial Classification (SIC) created for the first time in U.S. history in 1939 for the manufacturing products and in 1940 for the non-manufacturing products at 1-, 2-, and 3-digit levels. ${ }^{35}$ Specifically, we find the classification of manufacturing products in Volume I, part 3-"Alphabetic Index of Products, Establishments and Processes, 1939," and the classification of the products in Volume II, Part 3- "Alphabetic Index of Products, Establishments, and Services, 1940," published by the U.S. Office of Management and Budget in 1941 under the title of "Standard Industrial Classification Manual."

We then use these classifications to obtain the 1-, 2-, and 3-digit SIC codes of each firm's war products. We use this information to construct three variables: Switched 3-digit SIC, an indicator that equals to 1 for firms in which at least one war product had a different 3-digit SIC code than the peacetime products listed in 1941;

\footnotetext{
${ }^{34}$ https://www.ftserussell.com/data/mergent-archives.

${ }^{35}$ While the SIC categorizes products up to 4 digits, the product description is not accurate enough for such a detailed classification.
} 
Switched 2-digit SIC, an indicator that equals to 1 for firms in which at least one war product had a different 2-digit SIC code than the peacetime products listed in 1941; Switched 1-digit SIC, an indicator that equals to 1 for firms in which at least one war product had a different 1-digit SIC code than the peacetime products listed in 1941.

In the replacement schedules, firms also had to indicate the name of the companies with which they had an existing contract, as well as the list of products bought from and sold to them. We use this information to construct a list of upstream and downstream firms for the U.S. war contractors. First, we use the SIC codes to classify the 2-digit industry of the products sold to and bought from these companies. Then, we use the 1947 input-output tables to assess whether these products were upstream and downstream, relative to the products of the U.S. war contractor. ${ }^{36}$ To avoid any possible ambiguity, we keep only firms for which all the products had the same 2-digit industry. Out of 3,465 companies listed in the replacement schedules, we exclude 341 firms. Out of the remaining 3,124 firms, we were able to find financial statements for 1,816 of them, which represent the sample we use for the analysis in Section 6.1.

\section{Estimation of TFP}

We specify a Cobb-Douglas revenue production function for each 2-digit sector $s$, as follows:

$$
r_{i t}=a_{i t}+\beta_{l}^{s} l_{i t}+\beta_{k}^{s} k_{i t}+\beta_{m}^{s} m_{i t}+\epsilon_{i t},
$$

where all the lowercase variables are in logs, $r_{i t}$ is operating revenues of firm $i$ in year $t, a_{i t}$ denotes TFP, $l_{i t}$ is the number of employees, $k_{i t}$ is capital stock, $m_{i t}$ are intermediate inputs expenditures (raw materials and services), and $\epsilon_{i t}$ is the error. Table B1 contains the definition of these variables.

We estimate equation (2) using the methodology proposed by Gandhi, Navarro, and Rivers (2020) (GNR), which develops a nonparametric estimation of gross-output production functions that employs a "proxy variable" in a similar vein as prior work by Olley and Pakes (1996) (OP) and Levinsohn and Petrin (2003) (LP). More specifically, the GNR methodology consists in regressing revenue shares on inputs to identify the flexible input elasticity, first solving the partial differential equation and then integrating it into the dynamic panel/proxy variable structure to identify the remainder of the production function. Therefore, this procedure leads to a two-step nonparametric estimator in which different components of the production function are estimated via polynomial series in each stage.

The estimated factor coefficients for each 2-digit sector are reported in Table B2. In this table, we compare the coefficients estimated with the GNR methodology to the coefficients obtained from the LP and OP methodologies. Both LP and OP tend to overestimate the labor coefficients and underestimate the coefficients of capital and intermediate goods. This result is well-known in the literature (for example, Ackerberg, Caves, and Frazer, 2015) and stems from the fact that the labor coefficient is not identified in the first stage of OP and LP. Conversely, the OLS results substantially overestimate the output elasticity of intermediate inputs and underestimate both the capital and labor coefficients in every sector, confirming the severity of the transmission bias (as discussed by Gandhi, Navarro, and Rivers, 2020). Finally, it is worth noting that the GNR estimates are roughly comparable to the expenditure shares of intermediate goods, labor, and capital.

In summary, we use the sector-specific GNR coefficients to create the measure of TFP for each firm and year that we employ in the main analysis. However, our results do not hinge on using the GNR methodology. In fact, our findings are robust to estimating TFP with alternative algorithms, for example the popular OP and LP methods. Figure B1 shows the main event studies using TFP estimated with the GNR, OP, and LP methodologies. Regardless of the estimation technique, the result that trained firms started experiencing an increase in productivity after the delivery of the training stands. Moreover, the treatment effects are quantitatively similar across the three methods.

\section{Propensity Score Matching}

To show the robustness of the main findings, Section 5.1 discusses the results of several propensity score matching (PSM) between trained and nontrained firms. Table B3 shows the coefficients of the PSM algorithms.

${ }^{36}$ The 1947 input-output tables have been digitized by Soltan (2019) and are available at the following link: https://dataverse.harvard.edu/dataset.xhtml?persistentId=doi\%3A10.7910\%2FDVN\%2FMMHRU7 (downloaded in September 2018). 
Figure B1: Alternative Estimations of TFP

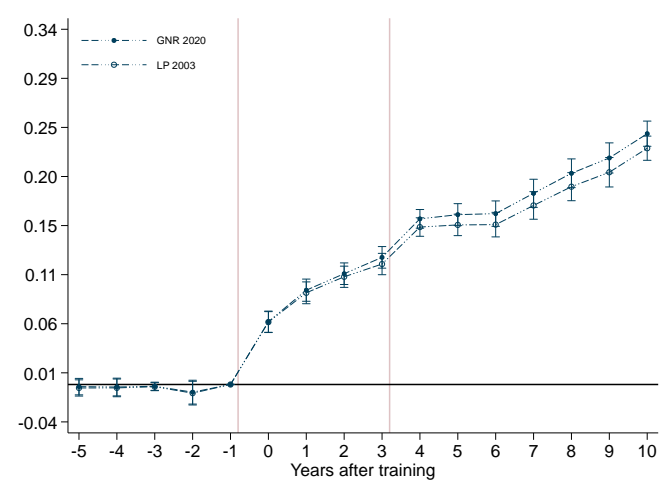

Panel A: TFP, LP (2003)

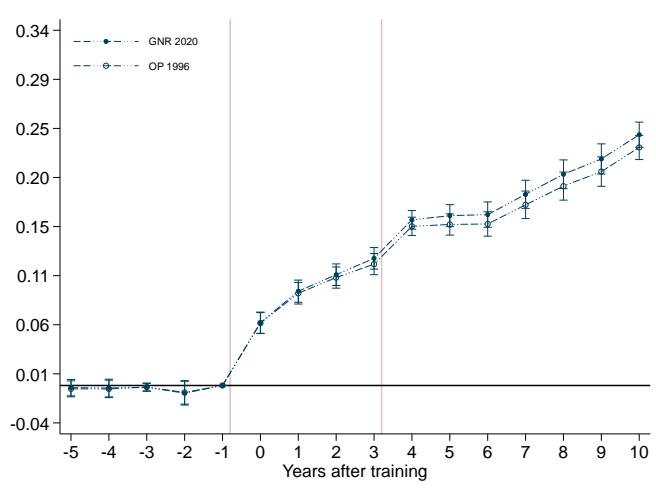

Panel B: TFP, OP (1996)

Notes. These graphs show the difference between estimating the TFP following the recent methodology by Gandhi, Navarro, and Rivers (2020) and the older methodologies proposed by Levinsohn and Petrin (2003) and Olley and Pakes (1996). 
Table B1: List, Definition, and Sources of Variables

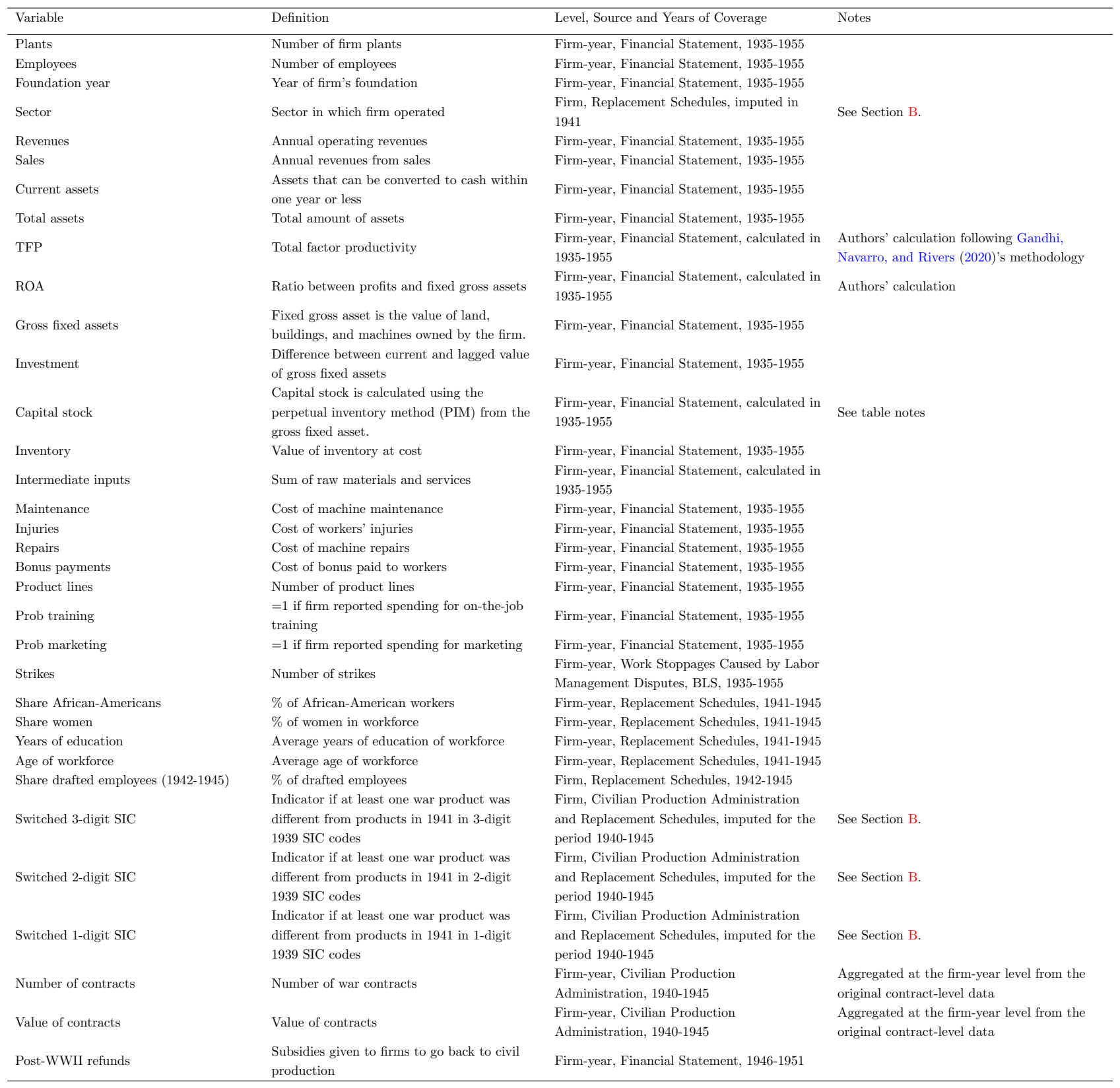

Notes. To compute capital stock, we use the following PIM formula: $P_{t+1} K_{t+1}=P_{t+1}(1-\delta) P_{t} K_{t}+$ $P_{t+1} I_{t+1}$, where $K$ is gross fixed asset, $I$ is investment, $P$ is the capital price (set equal to the interest rate on credit from 1935 to 1955 ), and $\delta$ is the depreciation rate (set equal to 5.5 percent). To estimate $K_{0} P_{0}$ at replacement costs from its historical cost reported in the financial statement, we used the $R^{G}$ factor suggested by Balakrishnan et al. (2000), computed as $R^{G}=\frac{\left[(1+g)^{\tau+1}-1\right](1+\pi)^{\tau}[(1+g)(1+\pi)-1]}{g\left\{[(1+g)(1+\pi)]^{\tau+1}-1\right\}}$ where $\tau$ is the average life of machines (assumed to be 15 years), $\pi$ is the average capital price $\frac{P_{t}}{P_{t-1}}$ from 1935 to 1955 (equal to 1.00476667), and $g$ is the (assumed constant) real GDP growth rate from 1935 to 1955 (equal to 1.0589524 ). 
Table B2: Estimation of Production Function

\begin{tabular}{|c|c|c|c|c|c|c|c|c|c|c|c|c|}
\hline & \multicolumn{3}{|c|}{ I. Food } & \multicolumn{3}{|c|}{ II. Textile } & \multicolumn{3}{|c|}{ III.Wood } & \multicolumn{3}{|c|}{ IV. Paper } \\
\hline & $\beta_{l}$ & $\beta_{k}$ & $\beta_{m}$ & $\beta_{l}$ & $\beta_{k}$ & $\beta_{m}$ & $\beta_{l}$ & $\beta_{k}$ & $\beta_{m}$ & $\beta_{l}$ & $\beta_{k}$ & $\beta_{m}$ \\
\hline GNR & $\begin{array}{c}0.26^{\text {*** }} \\
(0.02)\end{array}$ & $\begin{array}{c}0.25^{* * *} \\
(0.03)\end{array}$ & $\begin{array}{c}0.49^{* * *} \\
(0.05)\end{array}$ & $\begin{array}{c}0.22^{* * *} \\
(0.01)\end{array}$ & $\begin{array}{c}0.25^{* * *} \\
(0.03)\end{array}$ & $\begin{array}{c}0.55^{* * *} \\
(0.06)\end{array}$ & $\begin{array}{c}0.21^{* * *} \\
(0.02)\end{array}$ & $\begin{array}{c}0.18^{* * *} \\
(0.01)\end{array}$ & $\begin{array}{c}0.63^{* * *} \\
(0.04)\end{array}$ & $\begin{array}{c}0.22^{* * *} \\
(0.03)\end{array}$ & $\begin{array}{c}0.28^{* * *} \\
(0.03)\end{array}$ & $\begin{array}{c}0.51^{* * * *} \\
(0.06)\end{array}$ \\
\hline LP & $\begin{array}{c}0.32^{\text {*** }} \\
(0.04)\end{array}$ & $\begin{array}{c}0.20^{\text {*** }} \\
(0.02)\end{array}$ & $\begin{array}{c}0.51^{\text {*** }} \\
(0.03)\end{array}$ & $\begin{array}{c}0.31^{* * *} \\
(0.02)\end{array}$ & $\begin{array}{c}0.16^{* * *} \\
(0.01)\end{array}$ & $\begin{array}{c}0.54^{* * *} \\
(0.05)\end{array}$ & $\begin{array}{c}0.30^{* * *} \\
(0.01)\end{array}$ & $\begin{array}{c}0.15^{* * *} \\
(0.02)\end{array}$ & $\begin{array}{c}0.60^{* * *} \\
(0.03)\end{array}$ & $\begin{array}{c}0.31^{* * *} \\
(0.02)\end{array}$ & $\begin{array}{c}0.14^{* * *} \\
(0.01)\end{array}$ & $\begin{array}{c}0.51^{* * * *} \\
(0.04)\end{array}$ \\
\hline $\mathrm{OP}$ & $\begin{array}{c}0.33^{* * *} \\
(0.03)\end{array}$ & $\begin{array}{c}0.18^{* * *} \\
(0.01)\end{array}$ & $\begin{array}{c}0.53^{* * *} \\
(0.05)\end{array}$ & $\begin{array}{c}0.30^{* * *} \\
(0.03)\end{array}$ & $\begin{array}{c}0.18^{* * * *} \\
(0.04)\end{array}$ & $\begin{array}{c}0.53^{* * *} \\
(0.05)\end{array}$ & $\begin{array}{c}0.31^{* * *} \\
(0.02)\end{array}$ & $\begin{array}{c}0.16^{* * *} \\
(0.01)\end{array}$ & $\begin{array}{c}0.57^{* * *} \\
(0.04)\end{array}$ & $\begin{array}{c}0.32^{* * *} \\
(0.02)\end{array}$ & $\begin{array}{c}0.21^{* * *} \\
(0.02)\end{array}$ & $\begin{array}{c}0.49^{* * *} \\
(0.03)\end{array}$ \\
\hline OLS & $\begin{array}{c}0.20^{\text {*** }} \\
(0.01)\end{array}$ & $\begin{array}{c}0.15^{* * *} \\
(0.02)\end{array}$ & $\begin{array}{c}0.65^{* * *} \\
(0.05)\end{array}$ & $\begin{array}{c}0.18^{* * *} \\
(0.03)\end{array}$ & $\begin{array}{c}0.20^{* * * *} \\
(0.02)\end{array}$ & $\begin{array}{c}0.62^{* * *} \\
(0.06)\end{array}$ & $\begin{array}{c}0.15^{* * *} \\
(0.02)\end{array}$ & $\begin{array}{c}0.16^{* * *} \\
(0.01)\end{array}$ & $\begin{array}{c}0.69^{* * *} \\
(0.05)\end{array}$ & $\begin{array}{c}0.17^{\text {*** }} \\
(0.02)\end{array}$ & $\begin{array}{c}0.21^{* * *} \\
(0.03)\end{array}$ & $\begin{array}{c}0.62^{* * * *} \\
(0.06)\end{array}$ \\
\hline \multirow[t]{3}{*}{ Expenditure Shares } & 0.24 & 0.26 & 0.50 & 0.20 & 0.26 & 0.57 & 0.20 & 0.22 & 0.60 & 0.21 & 0.26 & 0.54 \\
\hline & \multicolumn{3}{|c|}{ V. Machinery } & \multicolumn{3}{|c|}{ VI. Metals } & \multicolumn{3}{|c|}{ VII. Chemicals } & \multicolumn{3}{|c|}{ VIII. Construction } \\
\hline & $\beta_{l}$ & $\beta_{k}$ & $\beta_{m}$ & $\beta_{l}$ & $\beta_{k}$ & $\beta_{m}$ & $\beta_{l}$ & $\beta_{k}$ & $\beta_{m}$ & $\beta_{l}$ & $\beta_{k}$ & $\beta_{m}$ \\
\hline GNR & $\begin{array}{c}0.31^{* * *} \\
(0.02)\end{array}$ & $\begin{array}{c}0.20^{* * *} \\
(0.04)\end{array}$ & $\begin{array}{c}0.52^{\text {*** }} \\
(0.03)\end{array}$ & $\begin{array}{c}0.21^{* * *} \\
(0.01)\end{array}$ & $\begin{array}{c}0.19^{* * * *} \\
(0.02)\end{array}$ & $\begin{array}{c}0.61^{* * * *} \\
(0.04)\end{array}$ & $\begin{array}{c}0.21^{* * *} \\
(0.01)\end{array}$ & $\begin{array}{c}0.15^{* * *} \\
(0.02)\end{array}$ & $\begin{array}{c}0.63^{* * *} \\
(0.05)\end{array}$ & $\begin{array}{c}0.20^{* * *} \\
(0.03)\end{array}$ & $\begin{array}{c}0.31^{* * *} \\
(0.04)\end{array}$ & $\begin{array}{c}0.52^{* * * *} \\
(0.05)\end{array}$ \\
\hline LP & $\begin{array}{c}0.38^{* * *} \\
(0.02)\end{array}$ & $\begin{array}{c}0.15^{* * *} \\
(0.01)\end{array}$ & $\begin{array}{c}0.50^{\text {*** }} \\
(0.04)\end{array}$ & $\begin{array}{c}0.29^{* * *} \\
(0.02)\end{array}$ & $\begin{array}{c}0.14^{* * * *} \\
(0.02)\end{array}$ & $\begin{array}{c}0.59^{* * *} \\
(0.04)\end{array}$ & $\begin{array}{c}0.30^{* * *} \\
(0.04)\end{array}$ & $\begin{array}{c}0.14^{* * *} \\
(0.02)\end{array}$ & $\begin{array}{c}0.59^{* * *} \\
(0.05)\end{array}$ & $\begin{array}{c}0.30^{* * *} \\
(0.02)\end{array}$ & $\begin{array}{c}0.20^{* * *} \\
(0.02)\end{array}$ & $\begin{array}{c}0.51^{* * *} \\
(0.05)\end{array}$ \\
\hline $\mathrm{OP}$ & $\begin{array}{c}0.35^{* * *} \\
(0.03)\end{array}$ & $\begin{array}{c}0.17^{\text {*** }} \\
(0.02)\end{array}$ & $\begin{array}{c}0.51^{\text {*** }} \\
(0.03)\end{array}$ & $\begin{array}{c}0.27^{* * *} \\
(0.03)\end{array}$ & $\begin{array}{c}0.16^{* * *} \\
(0.01)\end{array}$ & $\begin{array}{c}0.55^{* * *} \\
(0.06)\end{array}$ & $\begin{array}{c}0.28^{* * *} \\
(0.03)\end{array}$ & $\begin{array}{c}0.15^{* * *} \\
(0.02)\end{array}$ & $\begin{array}{c}0.60^{* * *} \\
(0.06)\end{array}$ & $\begin{array}{c}0.28^{* * *} \\
(0.03)\end{array}$ & $\begin{array}{c}0.17^{\text {*** }} \\
(0.02)\end{array}$ & $\begin{array}{c}0.52^{* * *} \\
(0.04)\end{array}$ \\
\hline OLS & $\begin{array}{c}0.25^{* * *} \\
(0.02)\end{array}$ & $\begin{array}{c}0.15^{* * *} \\
(0.01)\end{array}$ & $\begin{array}{c}0.60^{* * *} \\
(0.06)\end{array}$ & $\begin{array}{c}0.18^{* * *} \\
(0.03)\end{array}$ & $\begin{array}{c}0.15^{* * *} \\
(0.02)\end{array}$ & $\begin{array}{c}0.67^{* * *} \\
(0.04)\end{array}$ & $\begin{array}{c}0.18^{* * *} \\
(0.04)\end{array}$ & $\begin{array}{c}0.11^{* * *} \\
(0.02)\end{array}$ & $\begin{array}{c}0.72^{* * *} \\
(0.04)\end{array}$ & $\begin{array}{c}0.17^{* * *} \\
(0.02)\end{array}$ & $\begin{array}{c}0.20^{* * *} \\
(0.01)\end{array}$ & $\begin{array}{c}0.65^{* * *} \\
(0.06)\end{array}$ \\
\hline \multirow[t]{3}{*}{ Expenditure Shares } & 0.29 & 0.22 & 0.55 & 0.19 & 0.22 & 0.58 & 0.17 & 0.15 & 0.68 & 0.20 & 0.22 & 0.61 \\
\hline & \multicolumn{3}{|c|}{ IX. Service } & \multicolumn{3}{|c|}{ X. Transportation } & \multicolumn{3}{|c|}{ XI. Communication } & & & \\
\hline & $\beta_{l}$ & $\beta_{k}$ & $\beta_{m}$ & $\beta_{l}$ & $\beta_{k}$ & $\beta_{m}$ & $\beta_{l}$ & $\beta_{k}$ & $\bar{\beta}_{m}$ & & & \\
\hline GNR & $\begin{array}{c}0.44^{* * *} \\
(0.04)\end{array}$ & $\begin{array}{c}0.15^{* * *} \\
(0.02)\end{array}$ & $\begin{array}{c}0.51^{* * *} \\
(0.05)\end{array}$ & $\begin{array}{c}0.23^{* * *} \\
(0.02)\end{array}$ & $\begin{array}{c}0.11^{* * * *} \\
(0.02)\end{array}$ & $\begin{array}{c}0.68^{* * *} \\
(0.05)\end{array}$ & $\begin{array}{c}0.25^{* * *} \\
(0.03)\end{array}$ & $\begin{array}{c}0.27^{* * *} \\
(0.04)\end{array}$ & $\begin{array}{c}0.50^{* * *} \\
(0.05)\end{array}$ & & & \\
\hline LP & $\begin{array}{c}0.48^{\text {*** }} \\
(0.02)\end{array}$ & $\begin{array}{c}0.13^{* * *} \\
(0.02)\end{array}$ & $\begin{array}{c}0.44^{* * *} \\
(0.05)\end{array}$ & $\begin{array}{c}0.27^{* * *} \\
(0.04)\end{array}$ & $\begin{array}{c}0.10^{* * * *} \\
(0.02)\end{array}$ & $\begin{array}{c}0.65^{* * *} \\
(0.06)\end{array}$ & $\begin{array}{c}0.35^{* * *} \\
(0.03)\end{array}$ & $\begin{array}{c}0.17^{* * *} \\
(0.02)\end{array}$ & $\begin{array}{c}0.50^{* * *} \\
(0.06)\end{array}$ & & & \\
\hline $\mathrm{OP}$ & $\begin{array}{c}0.44^{* * *} \\
(0.03)\end{array}$ & $\begin{array}{c}0.15^{* * *} \\
(0.01)\end{array}$ & $\begin{array}{c}0.46^{* * *} \\
(0.04)\end{array}$ & $\begin{array}{c}0.24^{* * *} \\
(0.03)\end{array}$ & $\begin{array}{c}0.15^{* * * *} \\
(0.01)\end{array}$ & $\begin{array}{c}0.60^{* * * *} \\
(0.07)\end{array}$ & $\begin{array}{c}0.31^{* * *} \\
(0.04)\end{array}$ & $\begin{array}{c}0.19^{* * *} \\
(0.02)\end{array}$ & $\begin{array}{c}0.52^{* * *} \\
(0.05)\end{array}$ & & & \\
\hline OLS & $\begin{array}{c}0.33^{* * *} \\
(0.03)\end{array}$ & $\begin{array}{c}0.13^{* * *} \\
(0.01)\end{array}$ & $\begin{array}{c}0.59^{* * *} \\
(0.06)\end{array}$ & $\begin{array}{c}0.20^{* * *} \\
(0.04)\end{array}$ & $\begin{array}{c}0.10^{* * * *} \\
(0.02)\end{array}$ & $\begin{array}{c}0.72^{* * * *} \\
(0.07)\end{array}$ & $\begin{array}{c}0.22^{* * *} \\
(0.03)\end{array}$ & $\begin{array}{c}0.23^{* * *} \\
(0.01)\end{array}$ & $\begin{array}{c}0.57^{* * *} \\
(0.06)\end{array}$ & & & \\
\hline Expenditure Shares & 0.39 & 0.17 & 0.55 & 0.25 & 0.15 & 0.63 & 0.22 & 0.25 & 0.54 & & & \\
\hline
\end{tabular}

Notes. Coefficients on labor $\left(\beta_{l}\right)$, capital $\left(\beta_{k}\right)$ and intermediate goods $\left(\beta_{m}\right)$ estimated with the methodology proposed by Gandhi, Navarro, and Rivers (2020) (GNR), Levinsohn and Petrin (2003) (LP), or Olley and Pakes (1996) (OP). Moreover, we show the coefficients from simple OLS regressions, as well as expenditure shares for each two-digit sector. ${ }^{* * *}$ denotes $1 \%,{ }^{* *}$ denotes $5 \%$, and ${ }^{*}$ denotes $10 \%$ significance. 
Table B3: Coefficients of PSM between Trained and Nontrained Firms

\begin{tabular}{|c|c|c|c|c|c|c|}
\hline & $\begin{array}{l}\text { TWI } \\
\text { (1) }\end{array}$ & $\begin{array}{l}\text { TWI } \\
(2)\end{array}$ & $\begin{array}{l}\text { TWI } \\
(3)\end{array}$ & $\begin{array}{l}\text { TWI } \\
(4)\end{array}$ & $\begin{array}{l}\text { TWI } \\
(5)\end{array}$ & $\begin{array}{l}\text { TWI } \\
(6)\end{array}$ \\
\hline Plants & $\begin{array}{c}0.0034 \\
(0.0061)\end{array}$ & $\begin{array}{c}0.0034 \\
(0.0027)\end{array}$ & $\begin{array}{l}-0.0308 \\
(0.0322)\end{array}$ & $\begin{array}{l}-0.0310 \\
(0.0323)\end{array}$ & $\begin{array}{l}-0.0330 \\
(0.0330)\end{array}$ & $\begin{array}{l}-0.0360 \\
(0.0334)\end{array}$ \\
\hline Employees & $\begin{array}{c}-0.0002^{* * *} \\
(0.0001)\end{array}$ & $\begin{array}{l}-0.0000 \\
(0.0000)\end{array}$ & $\begin{array}{c}-0.0004^{* * *} \\
(0.0001)\end{array}$ & $\begin{array}{c}-0.0004^{* * *} \\
(0.0001)\end{array}$ & $\begin{array}{c}-0.0004^{* * *} \\
(0.0001)\end{array}$ & $\begin{array}{l}-0.0001 \\
(0.0001)\end{array}$ \\
\hline TFP & $\begin{array}{c}-0.0739^{* *} \\
(0.0323)\end{array}$ & $\begin{array}{c}-0.0551^{* * *} \\
(0.0144)\end{array}$ & $\begin{array}{l}-0.0532 \\
(0.0330)\end{array}$ & $\begin{array}{c}-0.0549^{*} \\
(0.0332)\end{array}$ & $\begin{array}{l}-0.0538 \\
(0.0342)\end{array}$ & $\begin{array}{c}-0.0634^{*} \\
(0.0346)\end{array}$ \\
\hline Distance to nearest port & $\begin{array}{c}0.0001 \\
(0.0001)\end{array}$ & $\begin{array}{l}0.0001^{*} \\
(0.0001)\end{array}$ & $\begin{array}{c}0.0001 \\
(0.0001)\end{array}$ & $\begin{array}{c}0.0002 \\
(0.0002)\end{array}$ & $\begin{array}{c}0.0003 \\
(0.0002)\end{array}$ & $\begin{array}{c}0.0003 \\
(0.0002)\end{array}$ \\
\hline Distance to nearest railroad station & $\begin{array}{c}-0.0007^{*} \\
(0.0004)\end{array}$ & $\begin{array}{c}-0.0007^{* * *} \\
(0.0002)\end{array}$ & $\begin{array}{c}-0.0007^{*} \\
(0.0004)\end{array}$ & $\begin{array}{l}-0.0007 \\
(0.0004)\end{array}$ & $\begin{array}{l}-0.0009 \\
(0.0006)\end{array}$ & $\begin{array}{c}-0.0010^{*} \\
(0.0006)\end{array}$ \\
\hline Sales & $\begin{array}{c}0.0000^{* *} \\
(0.0000)\end{array}$ & $\begin{array}{c}0.0000 \\
(0.0000)\end{array}$ & $\begin{array}{c}0.0000^{* * *} \\
(0.0000)\end{array}$ & $\begin{array}{c}0.0000^{* * *} \\
(0.0000)\end{array}$ & $\begin{array}{c}0.0000^{* * *} \\
(0.0000)\end{array}$ & $\begin{array}{c}0.0000^{* * *} \\
(0.0000)\end{array}$ \\
\hline Manufacturing & $\begin{array}{l}-0.0190 \\
(0.0734)\end{array}$ & $\begin{array}{l}-0.0222 \\
(0.0328)\end{array}$ & $\begin{array}{l}-0.0206 \\
(0.0735)\end{array}$ & $\begin{array}{l}-0.0267 \\
(0.0739)\end{array}$ & $\begin{array}{l}-0.0581 \\
(0.0757)\end{array}$ & $\begin{array}{l}-0.0631 \\
(0.0764)\end{array}$ \\
\hline Transportation & $\begin{array}{l}-0.0506 \\
(0.0820)\end{array}$ & $\begin{array}{l}-0.0540 \\
(0.0367)\end{array}$ & $\begin{array}{l}-0.0516 \\
(0.0821)\end{array}$ & $\begin{array}{l}-0.0454 \\
(0.0824)\end{array}$ & $\begin{array}{l}-0.0820 \\
(0.0843)\end{array}$ & $\begin{array}{l}-0.0676 \\
(0.0851)\end{array}$ \\
\hline Services & $\begin{array}{c}0.0148 \\
(0.1088)\end{array}$ & $\begin{array}{c}0.0135 \\
(0.0486)\end{array}$ & $\begin{array}{c}0.0197 \\
(0.1088)\end{array}$ & $\begin{array}{c}0.0147 \\
(0.1094)\end{array}$ & $\begin{array}{l}-0.0160 \\
(0.1121)\end{array}$ & $\begin{array}{c}0.0057 \\
(0.1130)\end{array}$ \\
\hline Foundation year & & & $\begin{array}{l}-0.0041 \\
(0.0031)\end{array}$ & $\begin{array}{l}-0.0042 \\
(0.0031)\end{array}$ & $\begin{array}{l}-0.0048 \\
(0.0032)\end{array}$ & $\begin{array}{l}-0.0051 \\
(0.0032)\end{array}$ \\
\hline Inventory & & & $\begin{array}{c}0.0000 \\
(0.0000)\end{array}$ & $\begin{array}{c}0.0000 \\
(0.0000)\end{array}$ & $\begin{array}{c}0.0000 \\
(0.0000)\end{array}$ & $\begin{array}{c}0.0000 \\
(0.0000)\end{array}$ \\
\hline Capital & & & $\begin{array}{c}0.0000 \\
(0.0000)\end{array}$ & $\begin{array}{c}0.0000 \\
(0.0000)\end{array}$ & $\begin{array}{c}0.0000 \\
(0.0000)\end{array}$ & $\begin{array}{c}-0.0000^{* *} \\
(0.0000)\end{array}$ \\
\hline Current assets & & & $\begin{array}{c}0.0000 \\
(0.0000)\end{array}$ & $\begin{array}{c}0.0000 \\
(0.0000)\end{array}$ & $\begin{array}{c}0.0000 \\
(0.0000)\end{array}$ & $\begin{array}{c}0.0000 \\
(0.0000)\end{array}$ \\
\hline Investment & & & $\begin{array}{l}-0.0000 \\
(0.0000)\end{array}$ & $\begin{array}{l}-0.0000 \\
(0.0000)\end{array}$ & $\begin{array}{l}-0.0000 \\
(0.0000)\end{array}$ & $\begin{array}{l}-0.0000 \\
(0.0000)\end{array}$ \\
\hline Strikes & & & $\begin{array}{c}0.0503 \\
(0.0441)\end{array}$ & $\begin{array}{c}0.0520 \\
(0.0442)\end{array}$ & $\begin{array}{c}0.0481 \\
(0.0451)\end{array}$ & $\begin{array}{c}0.0551 \\
(0.0456)\end{array}$ \\
\hline Injuries & & & $\begin{array}{l}-0.0000 \\
(0.0000)\end{array}$ & $\begin{array}{l}-0.0000 \\
(0.0000)\end{array}$ & $\begin{array}{l}-0.0000 \\
(0.0000)\end{array}$ & $\begin{array}{l}-0.0000 \\
(0.0000)\end{array}$ \\
\hline Bonus & & & $\begin{array}{l}-0.0000 \\
(0.0000)\end{array}$ & $\begin{array}{c}-0.0000 * \\
(0.0000)\end{array}$ & $\begin{array}{l}-0.0000 \\
(0.0000)\end{array}$ & $\begin{array}{c}-0.0000^{*} \\
(0.0000)\end{array}$ \\
\hline Subsidiaries & & & $\begin{array}{c}0.0025 \\
(0.0293)\end{array}$ & $\begin{array}{c}0.0014 \\
(0.0294)\end{array}$ & $\begin{array}{c}0.0125 \\
(0.0301)\end{array}$ & $\begin{array}{c}0.0070 \\
(0.0303)\end{array}$ \\
\hline Observations & 11,575 & 57,867 & 11,575 & 11,575 & 11,575 & 11,567 \\
\hline Periods & -1 & {$[-5,-1]$} & -1 & -1 & -1 & -1 \\
\hline Year FEs & No & Yes & No & No & No & No \\
\hline District FEs & No & No & No & Yes & No & No \\
\hline Subdistrict FEs & No & No & No & No & Yes & Yes \\
\hline App. window FEs & No & No & No & No & No & Yes \\
\hline
\end{tabular}

Notes. This table shows the coefficients from different propensity score matching between trained and nontrained firms. Table A7 shows the main results using the different matched samples. $* * * \mathrm{p}<0.01$, $* * \mathrm{p}<0.05, * \mathrm{p}<0.1$. 


\section{Results on TWI Instructors' Assignments}

Table C1: Correlation Between TWI Training and Instructors' Composition

\begin{tabular}{|c|c|c|c|c|c|c|c|c|c|}
\hline & "J-I first & 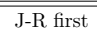 & 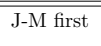 & 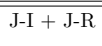 & 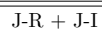 & 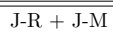 & 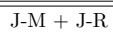 & "J-I + J-M & 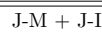 \\
\hline & (1) & $(2)$ & (3) & $(4)$ & (5) & (6) & (7) & $(8)$ & (9) \\
\hline Max J-I & $\begin{array}{c}0.215^{* * *} \\
(0.009)\end{array}$ & & & & & & & & \\
\hline Max J-R & & $\begin{array}{c}0.197^{* * *} \\
(0.010)\end{array}$ & & & & & & & \\
\hline Max J-M & & & $\begin{array}{c}0.192^{* * *} \\
(0.008)\end{array}$ & & & & & & \\
\hline Max J-I + J-R & & & & $\begin{array}{c}0.136^{* * *} \\
(0.013)\end{array}$ & & & & & \\
\hline Max J-R + J-I & & & & & $\begin{array}{c}0.128^{* * * *} \\
(0.011)\end{array}$ & & & & \\
\hline Max J-R + J-M & & & & & & $\begin{array}{c}0.166^{* * *} \\
(0.016)\end{array}$ & & & \\
\hline Max J-M + J-R & & & & & & & $\begin{array}{c}0.080^{* * *} \\
(0.013)\end{array}$ & & \\
\hline Max J-I + J-M & & & & & & & & $\begin{array}{c}0.152^{* * *} \\
(0.014)\end{array}$ & \\
\hline Max J-M + J-I & & & & & & & & & $\begin{array}{c}0.179^{* * * *} \\
(0.009)\end{array}$ \\
\hline Observations & 10,735 & 10,735 & 10,735 & 10,735 & 10,735 & 10,735 & 10,735 & 10,735 & 10,735 \\
\hline $\mathrm{R}^{2}$ & 0.189 & 0.192 & 0.188 & 0.146 & 0.147 & 0.146 & 0.121 & 0.135 & 0.150 \\
\hline Mean dep. var. & 0.18 & 0.18 & 0.17 & 0.09 & 0.10 & 0.12 & 0.10 & 0.13 & 0.11 \\
\hline
\end{tabular}

Notes. This table shows the correlations between the firm-level TWI training and the share of TWI instructors assigned to a firm's subdistrict and application window. The dependent variables are the following dummies: $\mathrm{J}$-I first $=1$ for firms that first received the Job-Instructions training; J-R first $=1$ for firms that first received the Job-Relations training; J-M first $=1$ for firms that first received the Job-Methods training; J-I + J-R $=1$ for firms that received first the J-I training and then the J-R training; J-R + J-I $=1$ for firms that received first the J-R training and then the J-I training; J-R $+\mathrm{J}-\mathrm{M}=1$ for firms that received first the J-R training and then the J-M training; J-M $+\mathrm{J}-\mathrm{R}=1$ for firms that received first the J-M training and then the J-R training; $\mathrm{J}-\mathrm{I}+\mathrm{J}-\mathrm{M}=1$ for firms that received first the $\mathrm{J}-\mathrm{I}$ training and then the $\mathrm{J}-\mathrm{M}$ training; J-M $+\mathrm{J}-\mathrm{I}=1$ for firms that received first the J-M training and then the J-I training. The independent variables measure the following: Max $\mathrm{J}-\mathrm{x}=1$ for firms that applied in subdistricts and application windows in which the share of instructors for training J-x (I, R, or M) was the highest; Max J-x + J-y = 1 for firms that applied in subdistricts and application windows in which the share of instructors for training $\mathrm{J}-\mathrm{x}$ (I, R, or M) was the highest and the share of instructors for training J-y $(y \neq x)$ was the second highest. The regressions also include fixed effects for county-sector pairs, the application window, and the number of days between the opening of the window and the firm application. The standard errors are clustered at the subdistrict-application window level. ${ }^{* * *} \mathrm{p}<0.01$, $* * \mathrm{p}<0.05,{ }^{*} \mathrm{p}<0.1$. 
Table C2: Correlation Between Firm and County Variables and TWI Instructors

\begin{tabular}{|c|c|c|c|c|c|c|c|c|c|}
\hline & $\begin{array}{c}\text { Max } \\
\text { J-I } \\
(1) \\
\end{array}$ & $\begin{array}{c}\text { Max } \\
\text { J-R } \\
(2) \\
\end{array}$ & $\begin{array}{c}\text { Max } \\
\text { J-M } \\
(3) \\
\end{array}$ & $\begin{array}{c}\text { Max } \\
\text { J-I }+ \text { J-R } \\
(4)\end{array}$ & $\begin{array}{c}\text { Max } \\
\text { J-R + J-I } \\
(5)\end{array}$ & $\begin{array}{c}\text { Max } \\
\mathrm{J}-\mathrm{R}+\mathrm{J}-\mathrm{M} \\
(6) \\
\end{array}$ & $\begin{array}{c}\text { Max } \\
\mathrm{J}-\mathrm{M}+\mathrm{J}-\mathrm{R} \\
(7) \\
\end{array}$ & $\begin{array}{c}\text { Max } \\
\text { J-I }+ \text { J-M } \\
(8) \\
\end{array}$ & $\begin{array}{c}\text { Max } \\
\text { J-M + J-I } \\
(9)\end{array}$ \\
\hline \multicolumn{10}{|c|}{$\underline{\text { Panel A: Regressions of TWI instructors on firm characteristics in period }-1}$} \\
\hline$p$-value of joint significance & 0.99 & 0.95 & 0.70 & 0.35 & 0.94 & 0.90 & 0.57 & 0.99 & 0.92 \\
\hline Observations & 10,735 & 10,735 & 10,735 & 10,735 & 10,735 & 10,735 & 10,735 & 10,735 & 10,735 \\
\hline \multicolumn{10}{|c|}{$\underline{\text { Panel B: Regressions of TWI instructors on firm characteristics, including number and value of government contracts, in period }-1}$} \\
\hline$p$-value of joint significance & 0.99 & 0.96 & 0.82 & 0.38 & 0.94 & 0.86 & 0.70 & 0.98 & 0.96 \\
\hline Observations & 10,727 & 10,727 & 10,727 & 10,727 & 10,727 & 10,727 & 10,727 & 10,727 & 10,727 \\
\hline \multicolumn{10}{|c|}{$\underline{\text { Panel C: Regressions of TWI instructors on county characteristics in year } 1940}$} \\
\hline$p$-value of joint significance & 0.01 & 0.14 & 0.01 & 0.01 & 0.71 & 0.07 & 0.86 & 0.23 & 0.12 \\
\hline Observations & 10,745 & 10,745 & 10,745 & 10,745 & 10,745 & 10,745 & 10,745 & 10,745 & 10,745 \\
\hline \multicolumn{10}{|c|}{$\underline{\text { Panel D: Regressions of TWI instructors on county characteristics in year } 1930}$} \\
\hline$p$-value of joint significance & 0.05 & 0.19 & 0.14 & 0.05 & 0.83 & 0.36 & 0.66 & 0.07 & 0.71 \\
\hline Observations & 10,859 & 10,859 & 10,859 & 10,859 & 10,859 & 10,859 & 10,859 & 10,859 & 10,859 \\
\hline$p$-value of joint significance & 0.04 & 0.18 & 0.12 & 0.01 & 0.57 & 0.09 & 0.72 & 0.40 & 0.85 \\
\hline Observations & 10,873 & 10,873 & 10,873 & 10,873 & 10,873 & 10,873 & 10,873 & 10,873 & 10,873 \\
\hline
\end{tabular}

Notes. Panel A shows the $p$-value of the test of joint significance of the coefficients of fifteen firm characteristics observed in period -1. The variables are: the logs of sales, value added, number of employees, number of plants, foundation year, the value of inventory, capital, current assets, investments, number of workers' strikes, monetary compensation for workers' injuries, performance-based bonus payments, number of subsidiaries, as well as distance to the nearest railroad station and distance to the nearest port. Panel $\mathrm{B}$ adds the inverse hyperbolic sine function of the number and value of government contracts. The regressions also include fixed effects for county-sector pairs, the application window, and the number of days between the opening of the window and the firm application. Panels C, D, and E show the $p$-value of the test of joint significance of the coefficients of several county characteristics measured in 1940, 1930, and 1920, respectively. The county-level variables are imputed to firms based on their location. These regressions include: log population, log of the manufacturing value added, log number of manufacturing establishments, log number of manufacturing employees, log average manufacturing wage, log total expenses in manufacturing, $\log$ value of manufacturing production, farms per capita, unemployment share (available only in 1930 and 1940), population per square mile, share of male residents, share of black population, share of urban population, share of illiterate population (available only in 1920 and 1930). County data are from IPUMS NHGIS, www.nhgis.org. The regressions also include fixed effects for subdistrict-sector pairs, the application window, and the number of days between the opening of the window and the firm application. The description of the dependent variables is in the notes of Table C1. Standard errors are clustered at the subdistrict-application window level.

Table C3: Autocorrelation between Current and Past TWI Instructors

\begin{tabular}{|c|c|c|c|c|c|c|c|c|c|}
\hline & $\begin{array}{c}\operatorname{Max} \\
\mathrm{J}-\mathrm{I}_{t} \\
(1)\end{array}$ & $\begin{array}{c}\operatorname{Max} \\
\mathrm{J}-\mathrm{R}_{t} \\
(2)\end{array}$ & $\begin{array}{c}\operatorname{Max} \\
\mathrm{J} \mathrm{M}_{t} \\
(3)\end{array}$ & $\begin{array}{c}\operatorname{Max} \\
\mathrm{J}-\mathrm{I}+\mathrm{J}-\mathrm{R}_{t} \\
(4)\end{array}$ & $\begin{array}{c}\operatorname{Max} \\
\mathrm{J}-\mathrm{R}+\mathrm{J}-\mathrm{I}_{t} \\
(5)\end{array}$ & $\begin{array}{c}\text { Max } \\
\mathrm{J}-\mathrm{R}+\mathrm{J}-\mathrm{M}_{t} \\
(6)\end{array}$ & $\begin{array}{c}\mathrm{Max} \\
\mathrm{J}-\mathrm{M}+\mathrm{J}-\mathrm{R}_{t} \\
(7)\end{array}$ & $\begin{array}{c}\operatorname{Max} \\
\mathrm{J}-\mathrm{I}+\mathrm{J}-\mathrm{M}_{t} \\
(8)\end{array}$ & $\begin{array}{c}\operatorname{Max} \\
\mathrm{J}-\mathrm{M}+\mathrm{J}-\mathrm{I}_{t} \\
(9)\end{array}$ \\
\hline $\operatorname{Max} \mathrm{J}-\mathrm{I}_{t-1}$ & $\begin{array}{c}0.002 \\
(0.022)\end{array}$ & & & & & & & & \\
\hline Max J-R ${ }_{t-1}$ & & $\begin{array}{c}0.019 \\
(0.025)\end{array}$ & & & & & & & \\
\hline Max J-M $\mathrm{M}_{t-1}$ & & & $\begin{array}{l}-0.002 \\
(0.022)\end{array}$ & & & & & & \\
\hline $\operatorname{Max} \mathrm{J}-\mathrm{I}+\mathrm{J}-\mathrm{R}_{t-1}$ & & & & $\begin{array}{c}-0.020 \\
(0.023)\end{array}$ & & & & & \\
\hline $\operatorname{Max} \mathrm{J}-\mathrm{R}+\mathrm{J}-\mathrm{I}_{t-1}$ & & & & & $\begin{array}{c}0.016 \\
(0.026)\end{array}$ & & & & \\
\hline Max J-R + J-M & & & & & & $\begin{array}{l}0.046^{*} \\
(0.026)\end{array}$ & & & \\
\hline $\operatorname{Max} \mathrm{J}-\mathrm{M}+\mathrm{J}-\mathrm{R}_{t-1}$ & & & & & & & $\begin{array}{l}-0.037^{*} \\
(0.020)\end{array}$ & & \\
\hline Max J-I $+\mathrm{J}^{-\mathrm{M}_{t-1}}$ & & & & & & & & $\begin{array}{c}0.012 \\
(0.023)\end{array}$ & \\
\hline Observations & 1,873 & 1,873 & 1,873 & 1,873 & 1,873 & 1,873 & 1,873 & 1,873 & 1,873 \\
\hline $\mathrm{R}^{2}$ & $<0.001$ & $<0.001$ & $<0.001$ & $<0.001$ & $<0.001$ & 0.002 & 0.001 & $<0.001$ & $<0.001$ \\
\hline
\end{tabular}

Notes. The table shows the autocorrelation between the current and past share of instructors for different types of TWI trainings. The unit of observation is one of 364 subdistricts and one of 10 application windows. The description of the dependent variables is in the notes of Table C1. The standard errors are clustered at the subdistrict level. ${ }^{* * *} \mathrm{p}<0.01,{ }^{* *} \mathrm{p}<0.05,{ }^{*} \mathrm{p}<0.1$. 
Table C4: IV and OLS Event Studies

\begin{tabular}{|c|c|c|c|c|c|c|}
\hline & \multicolumn{2}{|c|}{ Sales } & \multicolumn{2}{|c|}{ TFP } & \multicolumn{2}{|c|}{$\mathrm{ROA}$} \\
\hline & (1) & (2) & (3) & $(4)$ & $(5)$ & (6) \\
\hline J-I x Post TWI & $\begin{array}{c}0.120^{* * *} \\
(0.007)\end{array}$ & $\begin{array}{c}0.185^{* *} \\
(0.086)\end{array}$ & $\begin{array}{c}0.053^{* * *} \\
(0.005)\end{array}$ & $\begin{array}{c}0.055 \\
(0.054)\end{array}$ & $\begin{array}{l}-0.005 \\
(0.004)\end{array}$ & $\begin{array}{l}-0.025 \\
(0.056)\end{array}$ \\
\hline J-R x Post TWI & $\begin{array}{c}0.155^{* * *} \\
(0.008)\end{array}$ & $\begin{array}{c}0.263^{* * *} \\
(0.083)\end{array}$ & $\begin{array}{c}0.277^{* * *} \\
(0.004)\end{array}$ & $\begin{array}{c}0.313^{* * *} \\
(0.052)\end{array}$ & $\begin{array}{c}0.147^{* * *} \\
(0.005)\end{array}$ & $\begin{array}{l}0.135^{* *} \\
(0.054)\end{array}$ \\
\hline J-M x Post TWI & $\begin{array}{c}0.113^{* * *} \\
(0.007)\end{array}$ & $\begin{array}{c}0.178^{* * *} \\
(0.054)\end{array}$ & $\begin{array}{c}0.144^{* * *} \\
(0.004)\end{array}$ & $\begin{array}{c}0.154^{* * *} \\
(0.034)\end{array}$ & $\begin{array}{c}0.052^{* * *} \\
(0.006)\end{array}$ & $\begin{array}{c}0.024 \\
(0.036)\end{array}$ \\
\hline $\begin{array}{l}\text { Specification } \\
\text { Observations }\end{array}$ & $\begin{array}{c}\text { OLS } \\
67,472\end{array}$ & $\begin{array}{c}\text { IV } \\
67,472\end{array}$ & $\begin{array}{c}\text { OLS } \\
67,472\end{array}$ & $\begin{array}{c}\text { IV } \\
67,472\end{array}$ & $\begin{array}{c}\text { OLS } \\
67,472\end{array}$ & $\begin{array}{c}\text { IV } \\
67,472\end{array}$ \\
\hline
\end{tabular}

Notes. This table shows the coefficients of the interactions between the training variables and a post-TWI dummy variable. In the IV specifications, we instrument for the TWI training variables using three dummy variables that measure the allocation of TWI instructors to each subdistrict and application window: Max J-x $=1$ for firms that applied in subdistricts and application windows in which the share of instructors for training J-x (I, $\mathrm{R}$, or $\mathrm{M}$ ) was the highest. The sample includes applicant firms that either received only one TWI training or no training at all. The standard errors are clustered at the subdistrict-application window level. $* * * \mathrm{p}<0.01, * *$ $\mathrm{p}<0.05,{ }^{*} \mathrm{p}<0.1$. 